Historic, Archive Document

Do not assume content reflects current scientific knowledge, policies, or practices. 
62.39

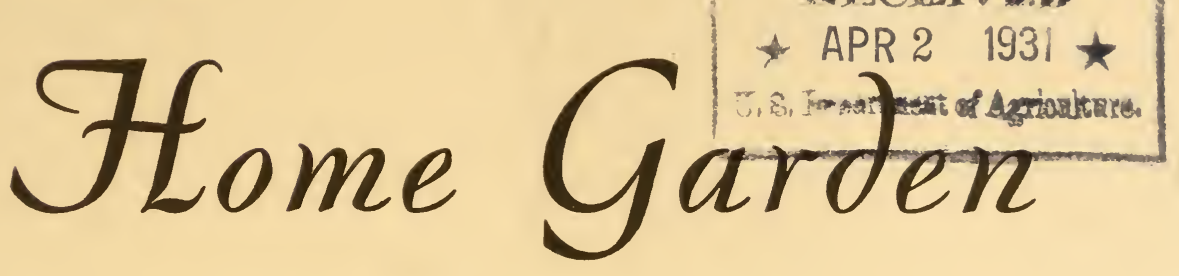

and

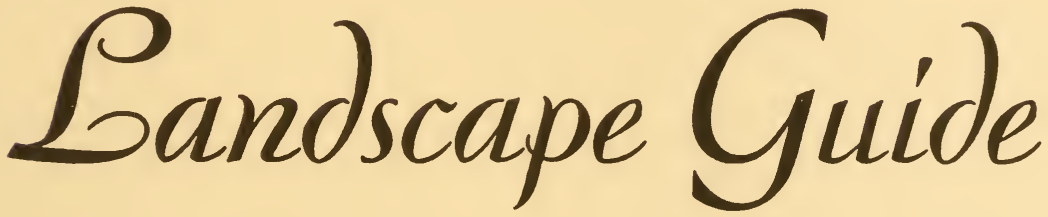

\section{LITTLEFIELD-WYMAN NURSERIES NORTH ABINGTON, MASSACHUSETTS}




\section{Index}

The contents of this Guide are arranged alphabetically according to the botanical names, with the common name given first.

$$
\text { Page }
$$

Introduction . . . . . . I

Climbing and Trailing Plants . . . . . 20

Conditions of Sale _ . . . . . . . . . 48

Evergreens . . . 37-41

Evergreen Shrubs _. . . . . . 43-44

Flowering Shrubs _ . 9-19

Fruit Trees _ . . . . 45

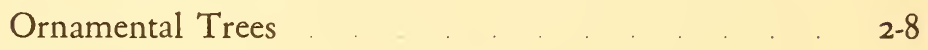

Perennials . . . . 25 25

Planting Instructions . . . . Back Cover

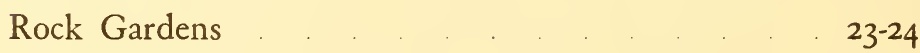

Roses . . . . . 46-47

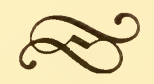

ROAD MAP TO OUR NURSERIES

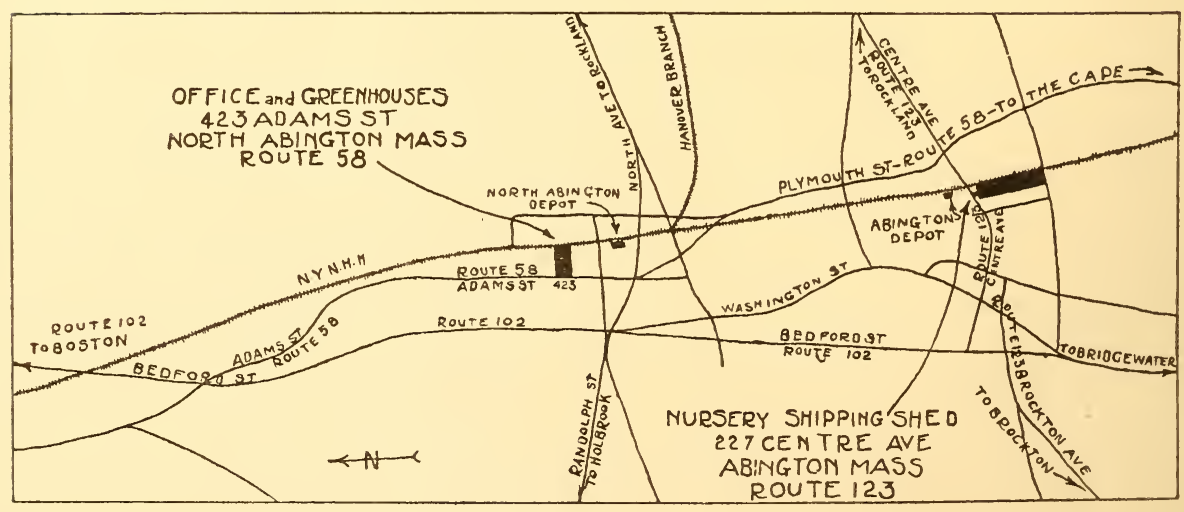


WITH a deep sense of appreciation, we dedicate to you, our friends, this 25th Anniversary Catalog.

As we look back over these years and receive the friendly greetings and expressions of satisfaction from those whom it has been our pleasure and privilege to serve, we feel reassured that our policy of offering only dependable stock of the highest quality at reasonable prices is amply endorsed.

Each year we offer new and rare varieties-but not until they have been thoroughly tested in our own Nursery and proved hardy and desirable. On the other hand, we are continually discarding those varieties which have developed undesirable traits. Growing the finest quality Nursery Stock is the first consideration of our organization.

This Anniversary we are offering our friends a few choice collections of hardy, desirable trees, shrubs, and perennials at special Anniversary prices. We emphasize that these varieties offered are highest quality stock and in no sense an inferior grade.

Visit us! Let us show you our fine healthy collection of nursery. grown stock. You will receive a genuine old-fashioned welcome.

Telephone

LITTLEFIELD-WYMAN NURSERIES,

ROCKLAND I 200

North Abingdon, Mass. 


\section{Ornamental Trees} THE shade trees of the Summer time, the flowering trees, and the richly hued trees
of the Autumn are in this group.

These trees possess luxuriant foliage, in response, it seems, to Nature's urge to do her utmost while she may. For this is the group which sheds its leaves in the Fall.

But-there is beauty, too, in the fine traceries of bare limbs against a winter sky.

Ornamental trees are best planted in the Spring when the frost has left the ground, or in the Autumn when the leaves have turned, before the ground has frozen.

Abbreviations: Suitable for Rock Gardens (R); Suitable for Sea Shore (S); Attracts Birds (B).

SIL VER MAPLE (Acer dasycarpum). Tall, luxuriant shade tree; grows best in moist soil. Brilliant autumnal coloring.

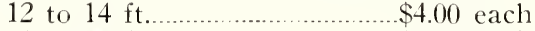
10 to $12 \mathrm{ft}$................................. $\$ 3.00 \mathrm{each}$ 6 to $8 \mathrm{ft} \ldots \$ 1.75$ each, $\$ 15.00$ per 10 WIER MAPLE (Acer dasycarpum wieri). Rapid growth, drooping branches, delicately cut foliage.

8 to $10 \mathrm{ft} \ldots \ldots+.00$ each
RED JAPANESE MAPLE (Acer palmatum rubrum). (R). Delicately cut leaves in rich, red tones. Gracefully ornamental. $2 \mathrm{r} / 2$ to $3 \mathrm{ft}$......................... $\$ 5.00$ each 2 to $2 \mathrm{r} / 2 \mathrm{ft} \ldots \ldots . . \$ 3.50$ each, $\$ 30.00$ per 10 18 to 24 in....... $\$ 2.50$ each, $\$ 22.50$ per 10 12 to 18 in...... $\$ 2.00$ each, $\$ 15.00$ per 10

STRIPED MAPLE (Acer pennsylvanicum). Small, ornamental tree with green and white striped bark. 6 to $8 \mathrm{ft}$. $\$ 2.50$ each

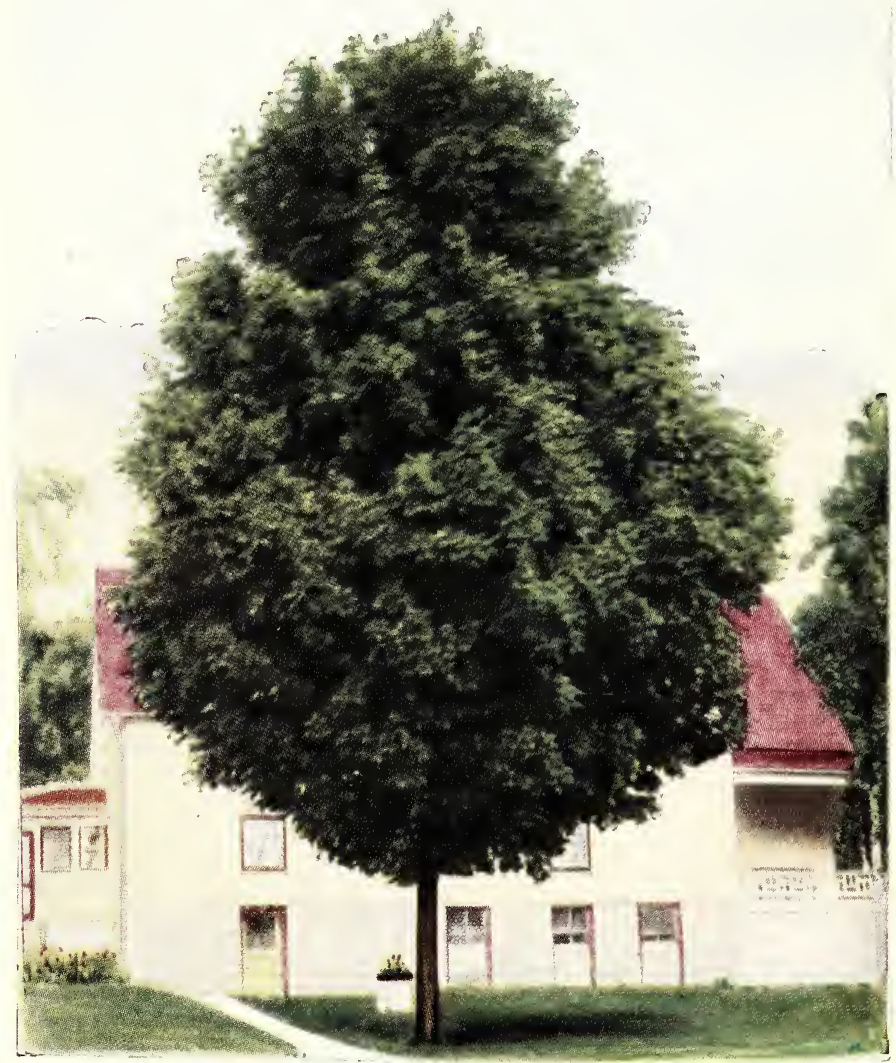

Silver Maple.

Five or more plants of one kind priced at the 10 rate. 
NORWAY MAPLE (Acer platanoides). (S). A splendid, heavily foliaged symmetrical tree.

10 to $12 \mathrm{ft} \ldots \ldots . . . \$ 5.00$ each, $\$ 4800$ per 10

8 to $10 \mathrm{ft}$........\$4.00 each, $\$ 37.50$ per 10

6 to $8 \mathrm{ft} . \ldots \ldots 2.75$ each, $\$ 25.00$ per $1 \mathrm{C}$

SCHWEDLER MAPLE (Acer schwedleri)

The purple leaved Norway Maple.

6 to $8 \mathrm{ft}$............ $\$ 5.00$ each, $\$ 45.00$ per 10

RED MAPLE (Acer rubrum). A tall, spreading tree, colorful in the Spring with clusters of reddish flowers, and in the Fall afire with brilliant foliage.

12 to $14 \mathrm{ft}$........................ $\$ 6.50$ each

10 to $12 \mathrm{ft} \ldots \ldots 500$ each, $\$ 45.00$ per 10

8 to $10 \mathrm{ft}$........\$3.50 each, $\$ 33.00$ per 10

6 to $8 \mathrm{ft}$.......\$2.75 each, $\$ 25.00$ per 10

SUGAR MAPLE (Acer saccharum). A thoroughly successful tree anywhere, broad headed and erect with silver lining underneath leaves.

Large specimens............... $\$ 20.00$ to $\$ 75.00$

16 to $18 \mathrm{ft} ., 2 \mathrm{~T} / 2$ to 3 in. cal....... $\$ 12.00$ ea.

14 to $16 \mathrm{ft} ., 2$ to $2 \mathrm{r} / 2 \mathrm{in}$. cal.......\$ 8.50 ea.

12 to $14 \mathrm{ft}$., $1 \frac{1}{2}$ to $13 / 4 \mathrm{in}$. cal ..\$ $\$ 6.00$ ea.

10 to $12 \mathrm{ft} ., 11 / 4$ to $1 \frac{1}{2} \mathrm{in}$. cal $\$ 5.00$ ea.

8 to $10 \mathrm{ft}$..........\$3.50 each, $\$ 33.00$ per 10

6 to $8 \mathrm{ft}$.........\$2.50 each, $\$ 24.00$ per 10

DEVIL'S-WALKINGSTICK (Aralia spinosa). (S). Thorn covered stems, immense leaves; clusters of white flowers followed by purple berries, a unique possession.

4 to $5 \mathrm{ft}$

$\$ 1.00$ each

EUROPEAN WHITE B I R C H (Betula alba). Tall, graceful, drooping with silvery bark.

8 to $10 \mathrm{ft}$

$\$ 3.00$ each

6 to $8 \mathrm{ft}$. $\$ 2.50$ each

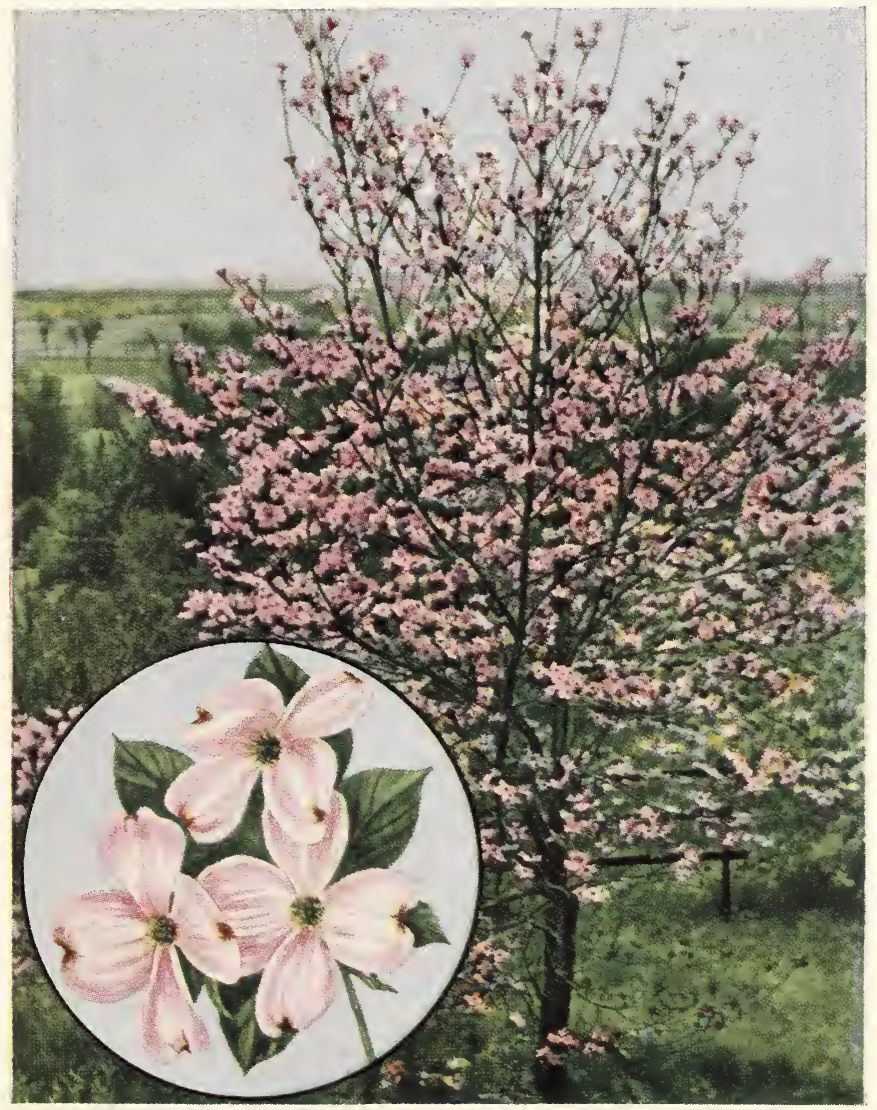

Red Flowering Dogwood.

Write for special prices on 25 or more of a kind. 


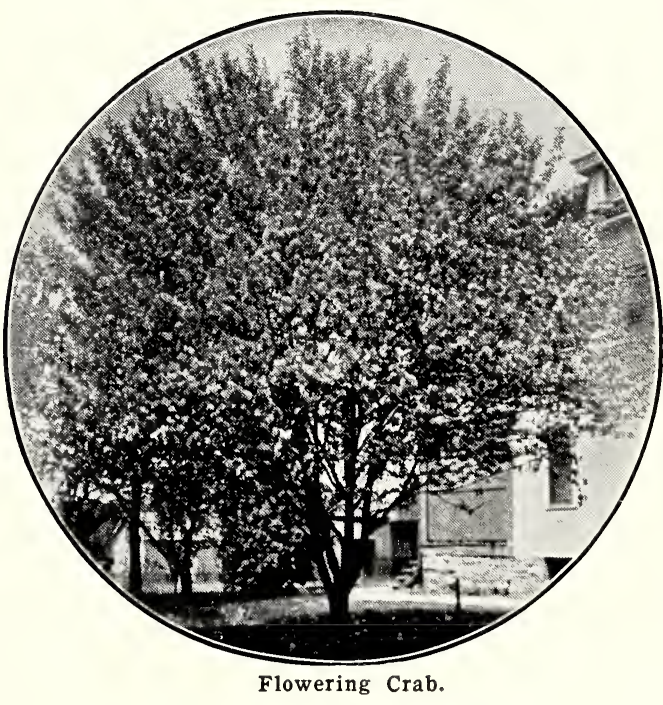

CANOE BIRCH (Betula papyrifera). (S). Large leaved, hardy; its white bark makes it particularly effective in group planting. 8 to $10 \mathrm{ft}$ $\$ 3.00$ each 6 to $8 \mathrm{ft} \ldots \ldots \ldots 2.50$ each, $\$ 22.50$ per 10 5 to $6 \mathrm{ft} \ldots \quad \$ 2.00$ each, $\$ 18.00$ per 10 4 to $5 \mathrm{ft} \ldots \ldots \ldots$...... $\$ 1.50$ each, $\$ 12.50$ per 10

CUTLEAF WEEPING BIRCH (Betula pendula gracilis). Picturesque, long pendant branches. A vigorous grower in rich, moist soil.

6 to $8 \mathrm{ft}$

$\$ 4.00$ each

5 to $6 \mathrm{ft} \ldots \ldots 3.50$ each, $\$ 30.00$ per 10

UMBRELLA CATALPA (Catalpa bignonioides nana). Luxuriant, glossy foliage for formal planting.

$4 \mathrm{yr}$. heads................................. $\$ 6.00$ each

3 yr. heads $\$ 3.50$ each, $\$ 32.50$ per 10

2 yr. heads......\$2.50 each, $\$ 22.50$ per 10

WESTERN CATALPA (Catalpa speciosa) Large, hardy, rapid grower. White flowers.

8 to $10 \mathrm{ft}$.........\$1.50 each, $\$ 14.00$ per 10

AMERICAN REDBUD (Cercis canadensis). Profuse purplish-red flowers in Spring.

2 to $3 \mathrm{ft} \quad \$ 1.00$ each, $\$ 9.00$ per 10

WHITE FRINGE (Chionanthus virginica) Splendid for lawn. White fringy flowers in Summer.

2 to $3 \mathrm{ft}$.

$\$ 2.50$ each, $\$ 22.50$ per 10

FLOWERING DOGWOOD (Cornus florida). A beautiful tree at every season. The white flowers appear almost before the leaves, making a mass of bloom.

3 to $4 \mathrm{ft}$. B\&B... $\$ 2.00$ each, $\$ 1800$ per 10
REDFLOWERING DOGWOOD (Cornus

f. rubra). Deep, rose colored flowers; blooms in early Spring like the above.

6 to $7 \mathrm{ft}$., B \& B.....................\$14.00 each

5 to $6 \mathrm{ft} ., \mathrm{B} \& \mathrm{~B}$.........................\$ 9.00 each

4 to $5 \mathrm{ft}$., B \& B .....................\$ 7.50 each

3 to $4 \mathrm{ft}$., B \& B........................ \$ 6.00 each

ARNOLD HAWTHORN (Crataegus arnoldiana). A small tree with spreading and ascending branches; conspicuous in August and September because of its profusion of bright crimson fruit.

3 to $3 \mathrm{t} / 2$ ft........\$2.00 each, $\$ 17.50$ per 10

$2 \mathrm{I} / 2$ to $3 \mathrm{ft} \ldots \ldots . . . \$ 1.50$ each, $\$ 14.00$ per 10

THICKET HAWTHORN (Crataegus coccinea). (S). Dense, thorny branches, shiny foliage, scarlet berries lasting to New Year.

6 to $7 \mathrm{ft}$. $\$ 4.50$ each

5 to $6 \mathrm{ft} . \ldots \ldots \ldots . . . . \$ 3.00$ each, $\$ 27.00$ per 10

SCARLET HAWTHORN (Crataegus coccinioides). A densely branched, roundtopped tree, radiant in the autumn with bright orange and scarlet foliage and erect clusters of crimson fruit.

4 to $5 \mathrm{ft}$............\$1.75 each, $\$ 16.00$ per 10

3 to $4 \mathrm{ft} \ldots \ldots \ldots . . . \$ 1.50$ each, $\$ 14.00$ per 10

2 to $3 \mathrm{ft} \ldots \ldots 1.00$ each, $\$ 8.50$ per 10

WASHINGTON HAWTHORN (Crataegus cordata). (S). Bright Fall coloring, clusters of red fruit.

3 to $4 \mathrm{ft} \ldots \ldots \ldots$

PAUL DOUBLE SCARLET TH ORN (Crataegus oxyacantha splendens). Small sturdy tree, rich rose blossoms.

4 to $5 \mathrm{ft}$................................ $\$ 3$ each

PLUMLEAF HAWTHORN (Crataegus prunifolia). Spreading, ascending, spiny branches, blossoms with pink centers, developing into scarlet fruit.

4 to $5 \mathrm{ft} \ldots \ldots \ldots . . . \$ 2.00$ each, $\$ 18.00$ per 10

3 to $4 \mathrm{ft} . \ldots \ldots . . . . . . \$ 1.75$ each, $\$ 16.00$ per 10

2 to $3 \mathrm{ft} \ldots \ldots \ldots$...... $\$ 1.50$ each, $\$ 14.00$ per 10

DOTTED HAWTHORN (Crataegus punctata). A handsome, wide spreading. sturdy tree with drooping clusters of bright yellow to dull red fruit, ripening and falling in October.

3 to $4 \mathrm{ft}$...........\$1.50 each, $\$ 14.00$ per 10 2 to $3 \mathrm{ft}$...........\$1.00 each, $\$ 9.00$ per 10

W H I T E A S H (Fraxinus americana). Handsome, broadleaved tree of rapid growth.

10 to $12 \mathrm{ft}$

$\$ 3.00$ each

8 to $10 \mathrm{ft} \quad \$ 2.00 \mathrm{each}$

MAIDENHAIR TREE (Ginkgo biloba). Oriental in appearance, fan shaped leaves become golden yellow in Fall; perfectly hardy.

8 to $10 \mathrm{ft} \quad \$ 5.50$ each, $\$ 50.00$ per 10 6 to $8 \mathrm{ft} \ldots \ldots \ldots \ldots$....... $\$ 4.00$ each, $\$ 3600$ per 10 


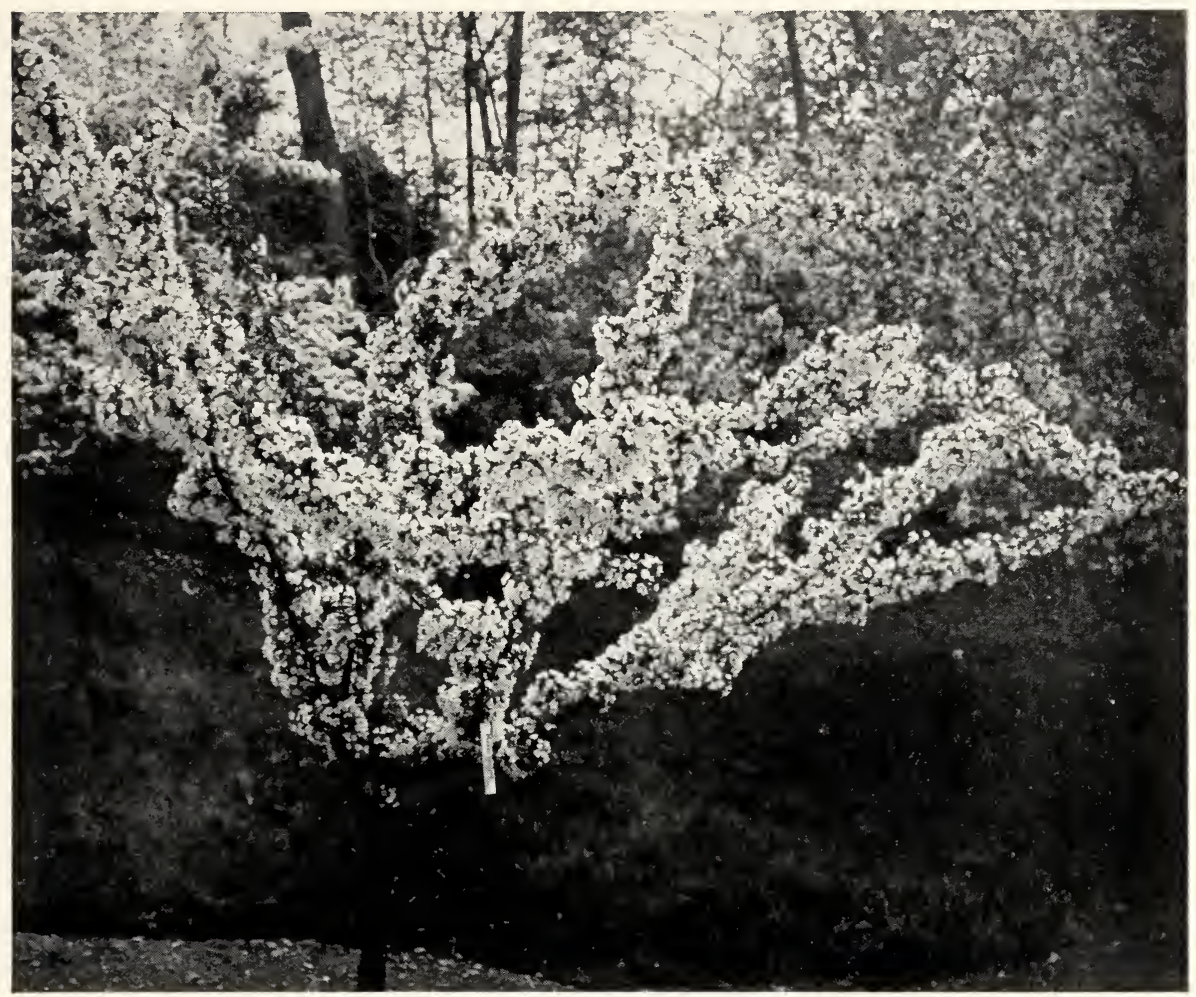

Tea Crab (Malus theifera). See Page 7.

COMMON HONEYLOCUST (Gleditsia triacanthos). (S). Stately, delicate fol1age, rapid growing.
10 to $12 \mathrm{ft}$
$\$ 3.00$ each
8 to $10 \mathrm{ft}$
$\$ 2.00$ each, $\$ 1800$ per 10
6 to $8 \mathrm{ft}$
$\$ 1.50$ each

SWEETGUM (Liquidambar styraciflua). Sturdy, symmetrical tree, the star-shaped leaves turn a glorious purple-crimson in Fall. Spiny fruit pods and corky ridges on twigs.

5 to $6 \mathrm{ft}$..

$\$ 4.00$ each

TULIPTREE (Liriodendron tulipifera). Large tree of dignity with tulip shaped, yellowish blossoms.

6 to $8 \mathrm{ft} \ldots \ldots 2.50$ each
5 to $6 \mathrm{ft} \ldots \ldots \ldots \ldots \ldots \ldots \ldots \ldots \ldots \ldots \ldots$

SAUCER MAGNOLIA (Magnolia soulangeana). Conical in shape, large leaves, ruddy pink fragrant flowers, followed by scarlet seed.

3 to $4 \mathrm{ft}$.

$\$ 1200$ each

2 to $3 \mathrm{ft}$

$\$ 9.00$ each

A R N O L D CRAB (Malus arnoldiana). Nearly double pink blossoms followed by yellow fruit, luxuriant foliage. By many considered the finest Crab.

4 to $5 \mathrm{ft} \ldots \quad \$ 3.00$ each, $\$ 27.00$ per 10

3 to $4 \mathrm{ft} \ldots \ldots \ldots$...... $\$ 2.00$ each, $\$ 18.00$ per 10

CARMINE CRAB (Malus atrosanguinea). Excellent lawn tree. covered with single crimson flowers in the Spring.

5 to $6 \mathrm{ft}$........... $\$ 3.00$ each, $\$ 27.00$ per 10

4 to $5 \mathrm{ft}$............\$2.00 each, $\$ 18.00$ per 10

3 to $4 \mathrm{ft}$......... $\$ 1.75$ each, $\$ 15.00$ per 10

SIBERIAN CRAB (Malus baccata). Upright with single, white, fragrant flowers.

4 to $5 \mathrm{ft}$........ $\$ 2.50$ each, $\$ 22.00$ per 10

3 to $4 \mathrm{ft} \ldots \ldots \ldots \ldots$...... $\$ 1.75$ each, $\$ 15.00$ per 10

JAPANESE FLOWERING CRAB (Malus floribunda). Very ornamental, abundance of deep pink blossoms appearing with leaves.

6 to $7 \mathrm{ft} \ldots \ldots \ldots \ldots . . . \$ 5.00$ each, $\$ 48.00$ per 10

5 to $6 \mathrm{ft} \ldots \ldots . . . \$ 4.00$ each, $\$ 36.00$ per 10

4 to $5 \mathrm{ft}$......... $\$ 3.00$ each, $\$ 27.00$ per 10

BOB WHITE FLOWERING CRAB (Malus $f$. Bob White). (B). Similar to floribunda, except that it is dwarf and more floriferous and fruitful. It derives its 
name from the bird "Bob White," which is especially fond of its fruit.

4 to $5 \mathrm{ft}$...........\$3.50 each, $\$ 30.00$ per 10

BECHTEL CRAB (Malus ioensis plena). Beautiful, shell-pink, semi-double blossoms like miniature roses. A joy to own.

3 to $4 \mathrm{ft}$........... $\$ 2.00$ each, $\$ 18.00$ per 10

REDVEIN CRAB (Malus niedzwetzkyana) Larger than most Crabs, with deep pink blossoms.

5 to $6 \mathrm{ft}$.

$\$ 3.00$ each, $\$ 27.00$ per 10

CHERRY CRAB (Malus robusta). Vigorous tree with white or pale pink blossoms followed by yellow fruit, crimson touched.

5 to $6 \mathrm{ft}$..........\$3.00 each, $\$ 27.00$ per 10

4 to $5 \mathrm{ft}$........... $\$ 2.50$ each, $\$ 22.50$ per 10

3 to $4 \mathrm{ft} . \ldots \ldots \ldots . . \$ 2.00$ each, $\$ 18.00$ per 10

SNOW HILL CRAB (Malus r. Snow Hill) Similar to robusta except whiter, and blooms more freely.

3 to $4 \mathrm{ft}$.
$\$ 6.00$ each
SARGENT CRAB (Malus sargenti). A dwarf tree with white blossoms and showy red fruit.

3 to $4 \mathrm{ft} \ldots \ldots \ldots \ldots$..... $\$ 2.75$ each, $\$ 25.00$ per 10 2 to $3 \mathrm{ft}$...........\$2.00 each, $\$ 17.50$ per 10

SCHEIDECKER CRAB (Malus scheideckeri). Larger, double flowers of light rose color that last a long time.

5 to $6 \mathrm{ft}$......... $\$ 3.00$ each, $\$ 27.00$ per 10

4 to $5 \mathrm{ft} \ldots \ldots \ldots . \$ 2.50$ each, $\$ 24.00$ per 10

3 to $4 \mathrm{ft}$............ $\$ 2.00$ each, $\$ 17.50$ per 10

TORINGO CRAB (Malus sieboldi). Dense low shrub, late; dark rose colored buds contrasting beautifully with white petals.

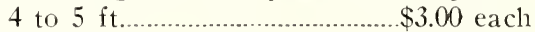

3 to $4 \mathrm{ft} \ldots \ldots \ldots . \$ 2.25$ each, $\$ 20.00$ per 10

CHINESE FLOWERING CRAB (Malus spectabilis). Small tree with coral-pink buds of unusual loveliness.

3 to $4 \mathrm{ft}$.

$\$ 2.00$ each

2 to $3 \mathrm{ft}$

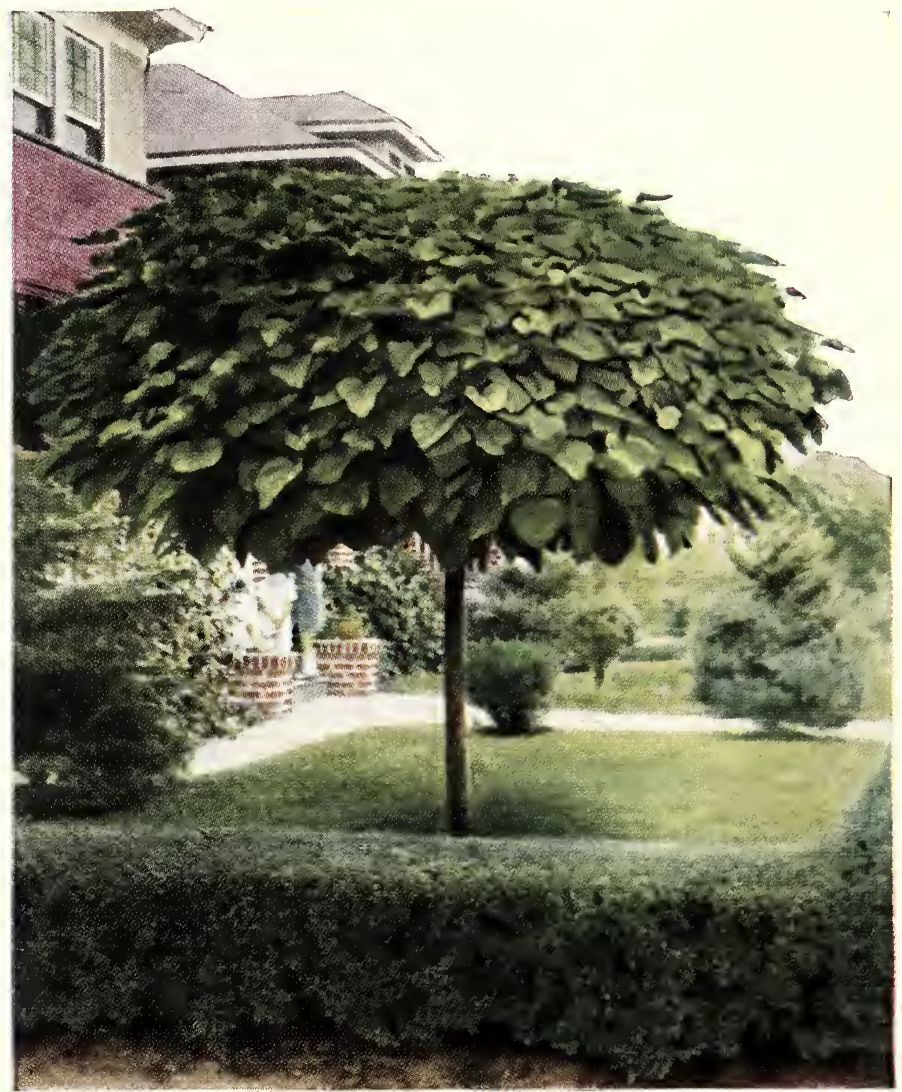

Catalpa Bungei.

Write for special prices on 25 or more of a kind. 


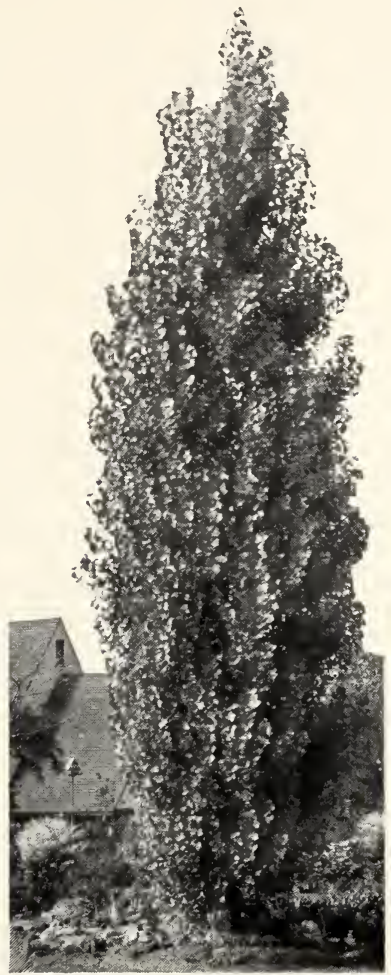

Lombardy Poplar.

TEA CRAB (Malus theifera). One of the most spectacular of flowering apples; irregular branches covered the entire length with pink blossoms.

5 to $6 \mathrm{ft} \ldots \ldots 5.50$ each, $\$ 50.00$ per 10

4 to $5 \mathrm{ft} \ldots \ldots \ldots+\$ 4.50$ each, $\$ 40.00$ per 10

3 to $4 \mathrm{ft} \ldots \ldots 3.50$ each, $\$ 33.00$ per 10

AMERICAN PLANETREE (Platanus occidentalis). Often called Sycamore or Buttonwood. A massively foliaged, large tree with heart-shaped leaves and picturesquely shaded gray and white bark. Unquestionably a success.

10 to $12 \mathrm{ft}$....... $\$ 3.00$ each, $\$ 27.00$ per 10 8 to $10 \mathrm{ft} \ldots \ldots 2.25$ each, $\$ 20.00$ per 10

BALM OF GILEAD POPLAR (Populus candicans). A big, spreading tree; also fast growing, whose buds have pleasant resinous fragrance in Spring.

12 to $14 \mathrm{ft} \ldots \ldots . . . \$ 2.00$ each, $\$ 17.50$ per 10

10 to $12 \mathrm{ft} \ldots \ldots \ldots . . . \$ 1.75$ each, $\$ 15.00$ per 10

6 to $8 \mathrm{ft} \ldots \$ 1.00$ each, $\$ 7.50$ per 10

CAROLINA POPLAR (Populus eugenei). A shade tree which grows rapidly in any soil. Attractive with heart-shaped foliage and gray green bark.

6 to 8 tt........ $\$ 1.25$ each, $\$ 10.00$ per 10

LOMBARDY POPLAR (Populus nigra italica). Exceedingly popular for screening and formal ornamental effects because of its columnar form.

12 to $14 \mathrm{ft}$...... $\$ 2.50$ each, $\$ 22.00$ per 10 10 to $12 \mathrm{ft} \ldots \ldots \ldots 2.00$ each, $\$ 18.00$ per 10 8 to $10 \mathrm{ft} . \ldots \ldots . . \$ 1.50$ each, $\$ 12.50$ per 10 6 to $8 \mathrm{ft} \ldots \ldots \ldots+\$ 1.25$ each, $\$ 11.00$ per 10

COMMON APRICOT (Prunus armeniaca)

A handsome and ornamental tree. Very hardy for New England gardens.

5 to $6 \mathrm{ft}$............................ $\$ 5.00$ each

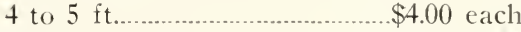

IMPROVED P U R P L L E A F PLUM (Prunus cerasifera othello). Keeps its rich bronze-purple hue throughout the season. Wine-red fruit.

5 to $6 \mathrm{ft} \ldots \ldots \ldots . . . \$ 2.75$ each, $\$ 25.00$ per 10 4 to $5 \mathrm{ft} \ldots \ldots \ldots$...... $\$ 2.25$ each, $\$ 20.00$ per 10

PURPLELEAF PLUM (Prunus c. pissardi). A small tree with pinkish white flowers and lustrous dark purple leaves. 6 to $8 \mathrm{ft}$........ $\$ 3.00$ each, $\$ 27.50$ per 10 5 to $6 \mathrm{ft} \ldots \ldots \ldots \ldots$........ $\$ 2.75$ each, $\$ 25.00$ per 10 4 to $5 \mathrm{ft} \ldots \ldots \ldots \ldots . . \$ 2.00$ each, $\$ 17.50$ per 10 3 to $4 \mathrm{ft} \ldots \ldots \ldots 1.50$ each, $\$ 12.50$ per 10 JAPANESE CHERRY (Prunus incisa). Has ascending and spreading branches, with twiggy branchlets, bearing pale pink to pure white flowers. Fine lawn specimen. 3 to $4 \mathrm{ft} \ldots \ldots \ldots \ldots \ldots \ldots \ldots$............... $\$ 30$ each

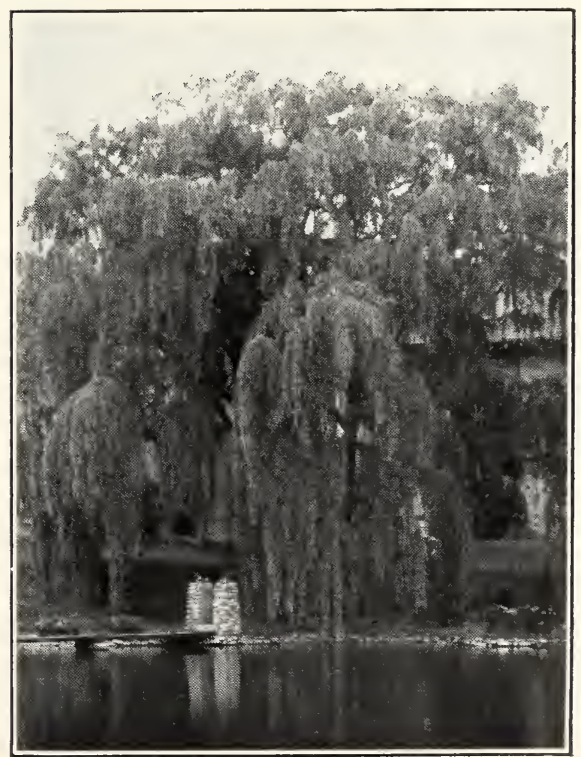

Weeping Willow.

Five or more plants of one kind priced at the 10 rate. 
SARGENT'S J A P A N E E CHERRY (Prunus sargenti). A handsome type with double pink to rose colored flowers. The young unfolding leaves are ruddy brown. This is a long-lived variety.

$$
3 \text { to } 4 \mathrm{ft} \text {. }
$$
$\$ 2.50$ each

HIGAN CHERRY (Prunus subhirtella). The first to open its blossoms. They are silvery pink, and completely hide the twiggy branchlets on this bush-like variety.

$31 / 2$ to $4 \mathrm{ft} \ldots \ldots . \$ 3.00$ each, $\$ 27.50$ per 10

3 to $3 \mathrm{I} / 2 \mathrm{ft} \ldots \ldots . \$ 2.50$ each, $\$ 22.50$ per 10

\section{JAPANESE FLOWERING CHERRIES}

A choice assortment noted for their showy, luxuriant blossoms in early Spring.

Beni Higan. Single blush pink.

5 to $6 \mathrm{ft}$
4 to $5 \mathrm{ft} \ldots \ldots \ldots \ldots \ldots \ldots \ldots \ldots \ldots \ldots \ldots \ldots \ldots$
3 to $4 \mathrm{ft} \ldots \ldots \ldots \ldots \ldots \ldots \ldots \ldots \ldots \ldots$

Kansan. Bright pink.
6 to $8 \mathrm{ft}$.
$\$ 6.50$ each
5 to $6 \mathrm{ft}$.
$\$ 5.50$ each
4 to $5 \mathrm{ft}$.
$\$ 4.00$ each

Kofugen. Buds crimson. blossoms old rose.

6 to $8 \mathrm{ft} \ldots \ldots \ldots \ldots \ldots \ldots \ldots$
5 to $6 \mathrm{ft} \ldots \ldots \ldots \ldots \ldots$
4

4 to $5 \mathrm{ft}$

$\$ 4.00$ each

Naden. Lovely double pink.

5 to $6 \mathrm{ft}$.

$\$ 5.50$ each

4 to $5 \mathrm{ft}$.

$\$ 4.00$ each

Yoshino. Buds red, blossoms single white. 7 to $8 \mathrm{ft}$.

$\$ 9.00$ each

6 to $7 \mathrm{ft}$.

5 to $6 \mathrm{ft}$.

$\$ 7.50$ each

$\$ 5.50$ each

WEEPING CHERRY (Prunus fruticosa pendula). Charming pendulant branches clustered with light pink blossoms. An ornamental asset.

$4 \mathrm{yr}$. heads, $6 \mathrm{ft}$. stems ........\$8.00 each

$3 \mathrm{yr}$. heads, $6 \mathrm{ft}$. stems .......\$5.00 each

$2 \mathrm{yr}$. heads, $6 \mathrm{ft}$. stems …....\$4.00 each

C H I N E E PEAR (Pyrus calleryana). Flowers little pinkish in bud, turning to white as they fully open. Flowers in early April, and is first Pyrus to blossom. Grows to about $30 \mathrm{ft}$.

5 to $6 \mathrm{ft}$...........\$3.50 each, $\$ 30.00$ per 10

4 to $5 \mathrm{ft}$......... $\$ 3.00$ each, $\$ 25.00$ per 10

PIN OAK (Quercus palustris). Has deeply cut leaves, highly colored in Fall.

Large specimens... $\$ 15.00$ to $\$ 50.00$ each

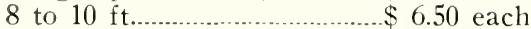

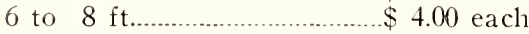

W I S C O S I N WEEPING WILLOW (Salix blanda). The hardiest of this group. Valuable because of its resistance to severe cold.

10 to $12 \mathrm{ft}$

$\$ 3.00$ each

6 to $8 \mathrm{ft}$. $\$ 1.25$ each
LAUREL WILLOW (Salix pentandra). (S). Highly recomemnded for either tall hedge, or as single specimen. Dark, glossy leaves.

10 to $12 \mathrm{ft}$........ $\$ 3.00$ each, $\$ 27.50$ per 10 8 to $10 \mathrm{ft} . . . . . \$ 1.75$ each, $\$ 15.00$ per 10

GOLDEN WILLOW (Salix vitellina). (S). A large tree of great dignity with bark of decided yellowish hue in winter.

10 to $12 \mathrm{ft}$........\$3.00 each, $\$ 27.50$ per 10

EUROPEAN MOUNTAIN ASH (Sorbus aucuparia). Clusters of orange-scarlet fruit make this a most ormamental, small lawn tree.

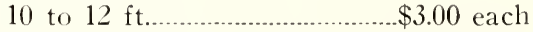

8 to $10 \mathrm{ft} \ldots \ldots . \$ 2.50$ each, $\$ 22.50$ per 10

6 to $8 \mathrm{ft} . \ldots \ldots . \$ 2.00$ each, $\$ 18.00$ per 10

LITTLELEAF EUROPEAN L I D E N

(Tilia cordata). Vigorous, handsome tree. 6 to $8 \mathrm{ft.............................} \mathrm{\$ 3.00} \mathrm{each}$

BIGLEAF EUROPEAN LINDEN (Tilia platyphyllos). Either one of these Lindens has unusual dignity.

6 to $8 \mathrm{ft}$.......

$\$ 2.00$ each

AMERICAN ELM (Ulmus americana). Deservedly one of America's foremost trees, of vaulted cathedral effect and simple grace.

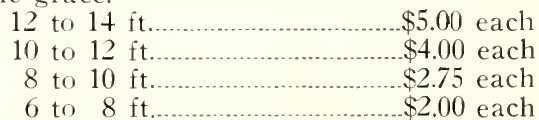

VASE-SHAPED A M E R I A N E L M (Ulmus a. vase-shaped). Of unusual symmetry.

6 to $8 \mathrm{ft}$.

$\$ 3.00$ each

5 to $6 \mathrm{ft}$.

$\$ 2.50$ each

CAMPERDOWN ELM (Ulmus glabra camperdowni). Vigorous irregular branches with uniform weeping head. This type is uncommon and of great charm.

$4 \mathrm{yr}$. heads............................... $\$ 6.00$ each

MOLINE ELM (Ulmus moline). A distinctive new variety with nearly parallel branches pointing upwards, then pendulous. The light green, shiny leaves growing in this fashion give a charming fountain effect.

10 to $12 \mathrm{ft} \ldots \$ 5.00$ each

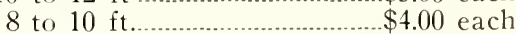

6 to $8 \mathrm{ft} . \ldots . . \$ 3.00$ each, $\$ 27.00$ per 10

5 to $6 \mathrm{ft} \ldots \ldots 2.00$ each, $\$ 18.00$ per 10

ASIATIC ELM (Ulmus pumila). Small, with slenderly delicate pendulous branches. Exquisite. Grows in very poor soil ; very hardy, and grows very rapidly. A very fine shade tree.

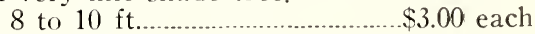
6 to $8 \mathrm{ft} \ldots \ldots \ldots 250$ each, $\$ 21.00$ per 10 


\section{Flowering Shrubs}

FOR the lover of beauty, this group offers a veritable paradise.

F Nature overwhelms us with an array of diversified colors and shapes. Used singly or in groups with contrasting or harmonizing colors, they add greatly to the charm and quiet grace of your home and grounds.

As a border planting, along paths or drives, on slopes and banks, as a softening influence along the foundation of home or garage, or as a beauty spot on the lawn, flowering shrubs take their natural place.

Abbreviations: Suitable for Rcck Gardens (R); Suitable for Sea Shore (S); Attracts Birds (B).

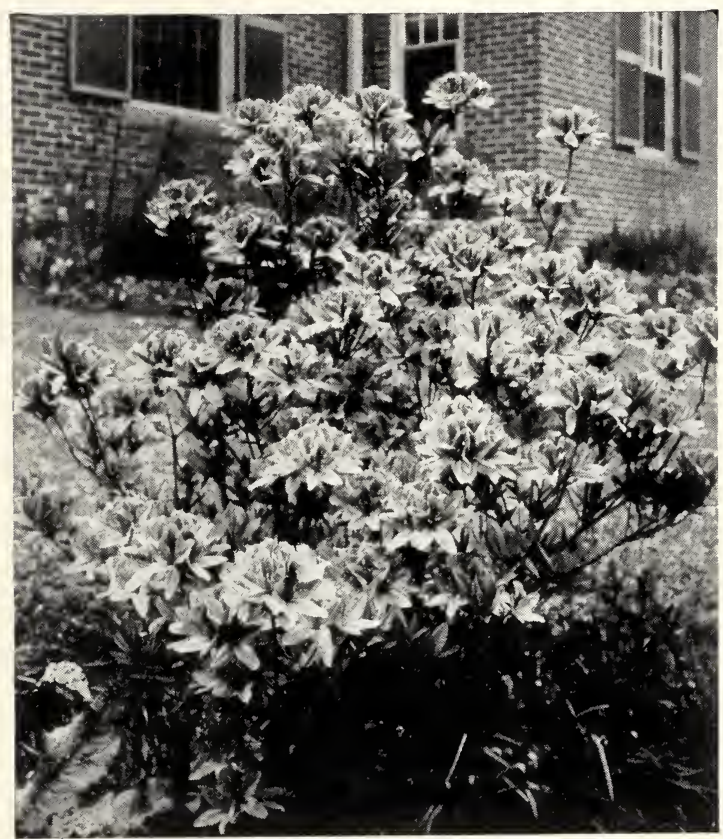

Azalea Mollis (Chinese Azalea).

RED CHOKEBERRY (Aronia arbutifolia) (BS). A fine border shrub with bright red berries. Each Per 10 2 to $3 \mathrm{ft} \ldots \ldots \ldots . . \$ 90 \quad \$ 8.00$ 18 to 24 in......... $\$ .75 \quad \$ 6.50$ Azaleas will be balled and burlapped (B \& B) without extra charge.

SWEET A Z A L E A (Azalea arborescens). Was ever a fairer flower made to grace a shady spot? This variety has white flowers and pink stamens.

$$
18 \text { to } 24 \text { in } \begin{array}{cc}
\text { Each } & \text { Per } 10 \\
\$ 3.50 & \$ 33.00
\end{array}
$$

15 to 18 in....... $\$ 3.00 \quad \$ 27.50$

FLAME AZALEA (Azalea calendulacea). Brilliant lemonyellow and orange flowers in late May. Mass with evergreens.

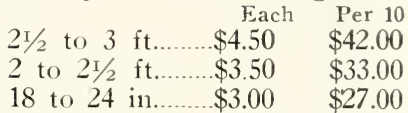

GRAY AZALEA (Azalea canescens). (R). Fragrant rosy-pink flowers. Each Per 10 18 to 24 in........\$2.75 $\$ 25.00$ 15 to 18 in........\$2.25 $\$ 20.00$

FIVELEAF ARALIA (Acanthopanax pentaphyllum). A strong, upright shrub with graceful arching, spiny branches covered with bright, shiny green foliage. Splendid for rockeries, shady places or as a hedge.

2 to $3 \mathrm{ft} \ldots \ldots \ldots \ldots . . \$$ each, $\$ 5.00$ per 10

DOWNY SHADBLOW (Amelanchier canadensis). (BS). A shrubby tree of delicate grace, showered with snowy white blossoms in May.

2 to $3 \mathrm{ft}$............\$1.00 each, $\$ 9.00$ per 10

INDIGOBUSH (Amorpha fruticosa). Violet purple flowers makes this an unusual possession, and a lacy background for more vivid coloring. Really lovely.

2 to $3 \mathrm{ft}$............. $\$ .50$ each, $\$ 4.50$ per 10
T O R H AZALEA (Azalea kaempferi). One of the handsomest of the Azaleas. Exceptionally hardy. Prolific orange-red to salmon-pink blossoms.

15 to $18 \mathrm{in} . . . . . \$ 4.00$ each, $\$ 36.00$ per 10 12 to 15 in...... $\$ 3.00$ each, $\$ 27.00$ per 10

CHINESE AZALEA (Azalea mollis). (R). Mixed colors. A dwarf variety of red, yellow and orange blossoms. Thrives in sunny places.

2 to $2 \mathrm{r} / 2 \mathrm{ft} \ldots \ldots . \$ 5.50$ each, $\$ 50.00$ per 10
18 to $24 \mathrm{in} \ldots \ldots . \$ 4.50$ each, $\$ 42.00$ per 10
15 to $18 \mathrm{in} . \ldots . \$ 3.50$ each, $\$ 33.00$ per 10
12 to $15 \mathrm{in} \ldots \ldots . \$ 3.00$ each, $\$ 25.00$ per 10


PINXTERBLOOM (A $z$ a le a nudiflora). (R). Deep pink to purplish blooms. Sandy soil.

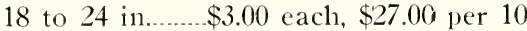
15 to 18 in........ $\$ 2.50$ each, $\$ 22.50$ per 10

KOREAN AZALEA (Azalea poukhanensis. (R). Large, fragrant rosy-lilac flowers all through May. A dense bushy growth.

15 to 18 in........\$4.00 each, $\$ 36.00$ per 10 12 to 15 in........ $\$ 3.50$ eacil, $\$ 32.50$ per 10

PINKSHELL AZALEA (Azalea vaseyi). Easily cultivated and perhaps the most profuse bloomer. White, pink or deep rose colored flowers in April or May.

2 to $2 \mathrm{r} / 2 \mathrm{ft} \ldots \$ 6.00$ each, $\$ 55.00$ per 10 18 to 24 in......\$4.50 each, $\$ 42.00$ per 10

S W A M P A Z A L E A (Azalea viscosa). Lovely fragrant white blossoms in July. Ideal for damp situation.

3 to $4 \mathrm{ft}$
$21 / 2$ to $3 \mathrm{ft} \ldots$
2 to $2 \mathrm{1} / 2 \mathrm{ft}$

JAPANESE BARBERRY (Berberis thunbergi). Ideal hedge plant of rich, green foliage turning scarlet in Fall. Bright red berries.

18 to 24 in.... $\$ 2.50$ per $10, \$ 18.00$ per 100 15 to 18 in...\$2.00 per $10, \$ 12.00$ per 100 12 to 15 in. $\$ 1.50$ per $10, \$ 9.00$ per 100
RED-LEAVED JAPANESE BARBERRY (Berberis $t$. atropurpurea). Maintaining a bright red foliage throughout season. 18 to $24 \mathrm{in......... \$ 1.00} \mathrm{each,} \$ 9.00$ per 10

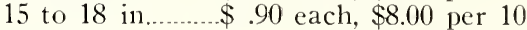
12 to 15 in........ \$ 60 each, $\$ 5.00$ per 10

BOX BARBERRY (Berberis t. minor). A miniature shrub of compact appearance for a low hedge.

15 to 18 in........\$ $\$ .75$ each, $\$ 6.50$ per 10 12 to 15 in.........\$ .65 each, $\$ 5.50$ per 10 10 to $12 \mathrm{in......... \$} \$ .50$ each, $\$ 4.50$ per 10

VERNA BARBERRY (Berberis vernae). A new variety of great charm; long slender bright red branches covered in June with short racemes of deep yellow flowers, and in Autumn with translucent salmon colored fruit. During the Summer it is a fountain of green covered with tiny leaves.

18 to 24 in......... $\$ .90$ each, $\$ 7.50$ per 10

EUROPEAN BARBERRY (Berberis vulgaris). A splendid, golden flowered variety with horny arching branches, with scarlet berries in Fall. Most desirable.

2 to $3 \mathrm{ft} \ldots \ldots \ldots \ldots . . . .60$ each, $\$ 4.50$ per 10

HARDY BUTTERFLYBUSH (Buddleia alternifolia). Has a bower of pendulous branches laden with purplish blossoms, red centered, in a background of lanceshaped leaves, dull green on the surface,

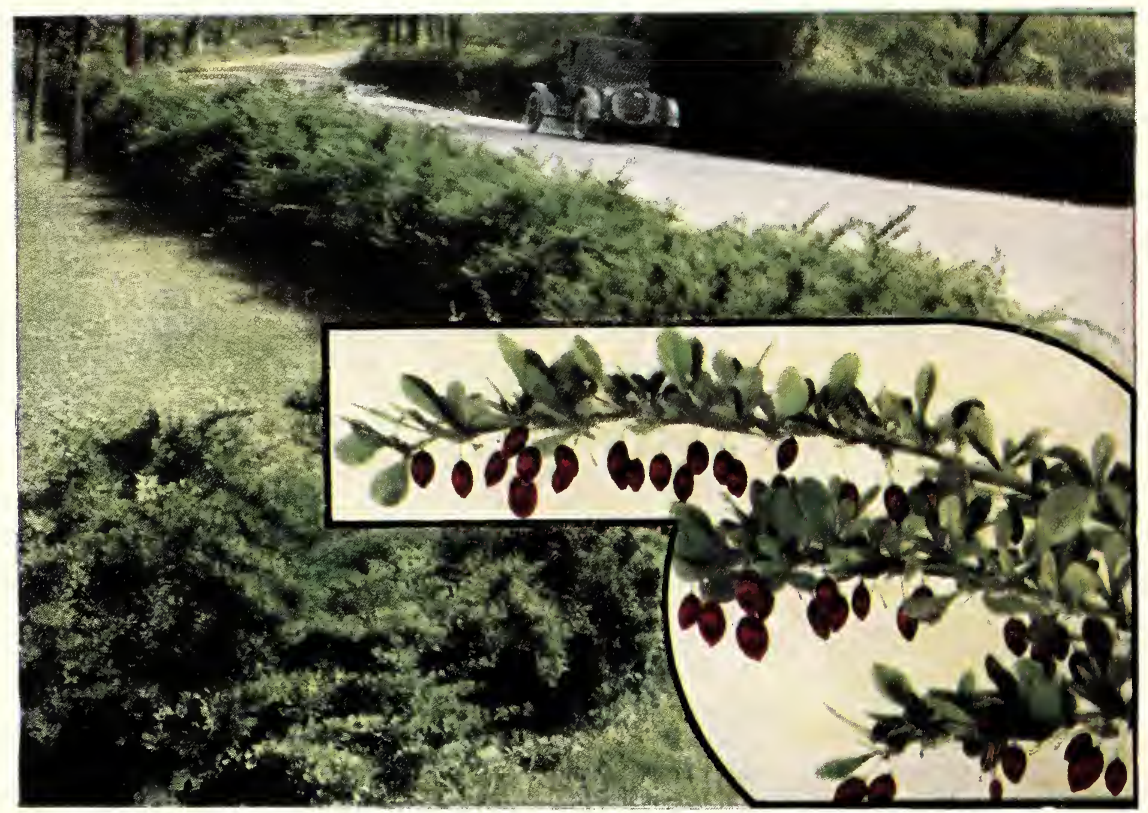

Japanese Barberry.

Write for special prices on 25 or more of a kind. 


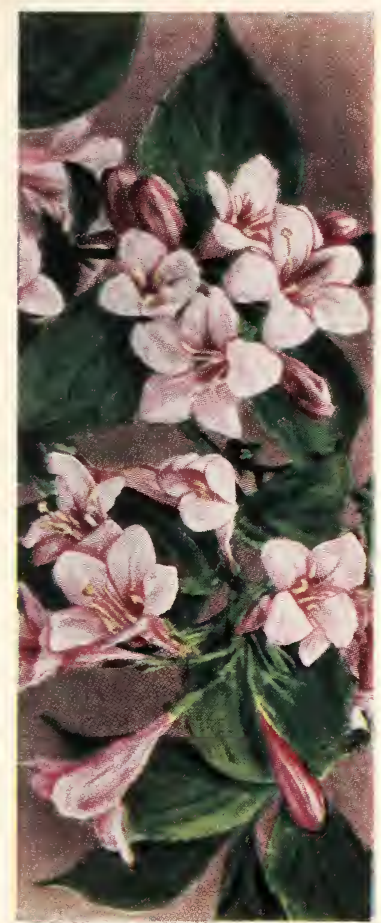

Weigela Rosea.

See Page 19.

\section{Shrubs lend a charm to your Landscape}

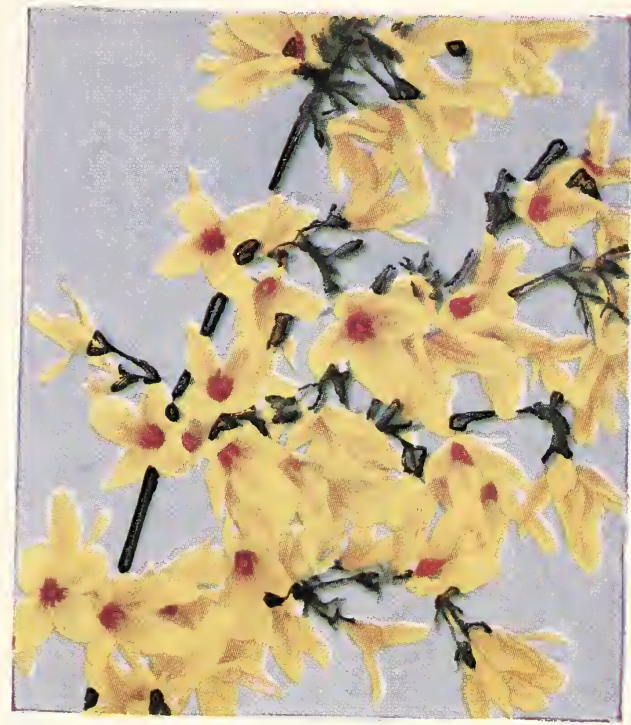

Forsythia Intermedia. See Page 12.

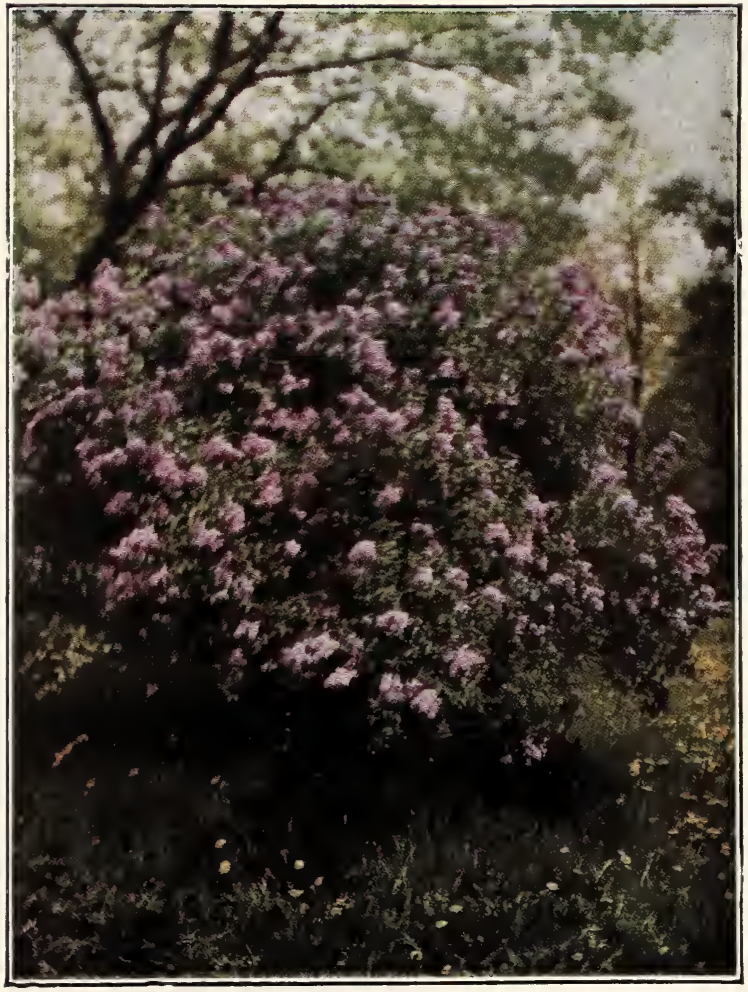

Syringa Vulgaris. See Page 17.

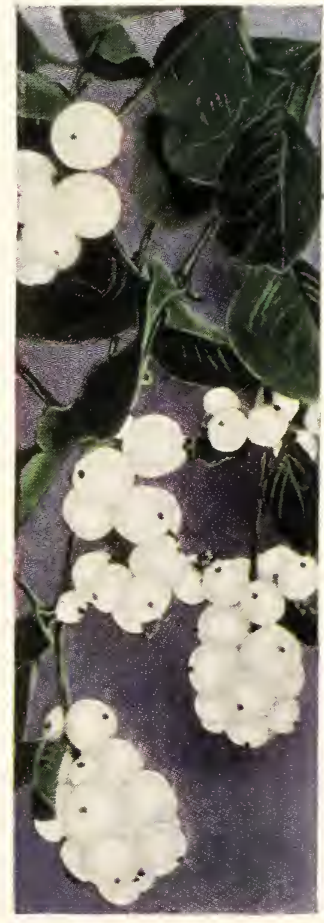

Symphoricarpos Racemosus. See Page 17 
gray lined. A beautiful and remarkably hardy plant.

2 to $3 \mathrm{ft}$.

$\$ 250$ each

18 to 24 in $\$ 2.00$ each

OXEYE BUTTERFLYBUSH (Buddleia davidi magnifica). Fragrant racemes of lavender flowers from August until frost. Plant in the Spring only.

3 years _......... $\$ .60$ each, $\$ 5.00$ per 10

2 years_._. $\quad \$ .50$ each, $\$ 4.00$ per 10

CHINESE BEAUTYBERRY (Callicarpa purpurea). Pink-tinted blossoms in August, followed by clustered violet-purple berries.

2 to $3 \mathrm{ft}$....... $\$ 50$ each, $\$ 4.50$ per 10

COMMON SWEETSHRUB (Calycanthus floridus). Interesting reddish - b row $\mathrm{n}$ shoots and glossy green leaves. Blooms all Summer.

3 to $4 \mathrm{ft}$.......... $\$ 1.00$ each, $\$ 9.00$ per 10

2 to $3 \mathrm{ft} \ldots \quad \$ .75$ each, $\$ 6.50$ per 10

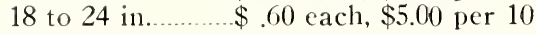

SUMMERSWEET (C l e th $\mathrm{r}$ a alnifolia). Thrives in damp, shady places which most shrubs cannot endure. A dainty shrub with creamy white flowers

2 to $3 \mathrm{ft}$........ \$ .75 each, $\$ 5.50$ per 10

18 to 24 in......... \$ .60 each, $\$ 4.50$ per 10

TATARIAN DOGWOOD (Cornus alba). (BS). Red-twigged and therefore most attractive with evergreens in winter. Small white blossoms in early Summer are in clusters, and nearly flat in appearance.

3 to $4 \mathrm{ft} \ldots \ldots \ldots \ldots$ each, $\$ 4.50$ per 10

2 to $3 \mathrm{ft} \ldots \ldots \ldots \ldots . . . . .50$ each, $\$ 3.50$ per 10

SILKY DOGWOOD (Cornus amomum). (B). Abundance of white flowers in June and lovely blue berries in October.

5 to $6 \mathrm{ft}$.......... $\$ 1.00$ each, $\$ 8.00$ per 10

4 to $5 \mathrm{ft}$..........\$ $\$ .85$ each, $\$ 7.00$ per 10

2 to $3 \mathrm{ft} \ldots \ldots \ldots . .65$ each, $\$ 5.00$ per 10

GRAY DOGWOOD (Cornus Faniculata).

(BS). An outstanding free flowering shrub. White fruit and red stems showy in the Fall.

4 to $5 \mathrm{ft}$.

$\$ 1.75$ each

3 to $4 \mathrm{ft}$. $\$ 1.00$ each, $\$ 8.00$ per 10

2 to $3 \mathrm{ft}$. $\$ 75$ each, $\$ 6.50$ per 10

RED-OSIER DOGWOOD (Cornus stolonifera). (B). A beautiful type with bloodred branches, abundance of blossoms, followed by white berries.

3 to $4 \mathrm{ft}$............ \$ 60 each, $\$ 5.00$ per 10 2 to $3 \mathrm{ft} \ldots \ldots \ldots \ldots . . . .50$ each $\$ 450$ per 10

FLOWERING QUINCE (Cydonia japonica). (S). A blaze of scarlet in Spring, then dark green glossy foliage. Ideal for hedge.

2 to $3 \mathrm{ft} \ldots \ldots \ldots$....... $\$ 90$ each, $\$ 8.00$ per 10
18 to 24 in $\$ .75$ each, $\$ 6.00$ per 10
FEBRUARY DAPHNE (Daphne mezereum). Exquisitely fragrant tiny purple flowers in very early Spring.

18 to 24 in., B \& B.................\$2.50 each

15 to 18 in., B \& B...................\$1.50 each

12 to 15 in., B \& B...................\$1.00 each

SLENDER DEUTZIA (Deutzia gracilis). Charming arching branches laden with pure white flowers.

15 to 18 in.......... $\$ .75$ each, $\$ 5.50$ per 10

LEMOINE DEUTZIA (Deutzia lemoinei). Hardy and stout with luxuriant white flowers in long sprays. Very decorative. 2 to $2 \mathrm{r} / 2 \mathrm{ft}$......\$ $\$ .60$ each, $\$ 5.50$ per 10 18 to 24 in......\$ $\$ .50$ each, $\$ 4.50$ per 10

D O U B L E PINK DEUTZIA (Deutzia scabra crenata). The pride of this group - tall and profusely covered with double white, pink tinged flowers in July.

3 to $4 \mathrm{ft} \ldots \ldots \ldots . . \$ 2$ each, $\$ 6.00$ per 10

2 to $3 \mathrm{ft} \ldots \ldots . . . \$ 0$ each, $\$ 5.00$ per 10

PRIDE OF ROCHESTER (Deutzia s. Pride of Rochester). One of the tallest Deutzias, blooming profusely in July. Large double white flowers, backs of petals tinged rose.

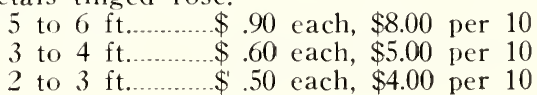

DWARF BUSH-HONEYSUCKLE (Diervilla trifida). Low lying shrub, yellow flowers in flat topped clusters. Spreads rapidly by underground shoots and therefore splendid for banks.

18 to 24 in......... \$ .50 each, $\$ 4.50$ per 10

WINGED EUONYMUS (Euonymus alatus). (S). Yellowish flowers followed by red fruit. Distinctive in that the wood is square.

2 to $3 \mathrm{ft}$........... $\$ 1.50$ each, $\$ 13.50$ per 10

18 to 24 in....... $\$ 1.00$ each, $\$ 9.00$ per 10

EUROPEAN BURNINGBUSH (Euonymus europaeus). (S). Upright, with foliage turning crimson in Fall. Yellow flowers turning to orange. Scarlet fruit.

3 to to $4 \mathrm{ft}$......... $\$ 1.25$ each, $\$ 10.00$ per 10

2 to $3 \mathrm{ft} . \ldots \ldots \ldots . . . . \$ .75$ each, $\$ 6.50$ per 10

18 to 24 in.......\$ .65 each, $\$ 6.00$ per 10

C O M M O N PEARLBUSH (Exochorda grandiflora). Snow white, pearl-like flowers cover this fine shrub.

2 to $3 \mathrm{ft} \ldots \ldots \ldots \ldots . . . . \$ 25$ each, $\$ 6.50$ per 10 18 to 24 in........\$ .65 each, $\$ 5.50$ per 10

BORDER FORSYTHIA (Forsythia intermedia). (S). This variety has low arching branches.

2 to $3 \mathrm{ft}$...........\$ $\$ .60$ each, $\$ 4.50$ per 10 18 to 24 in......... $\$ .50$ each, $\$ 4.00$ per 10 


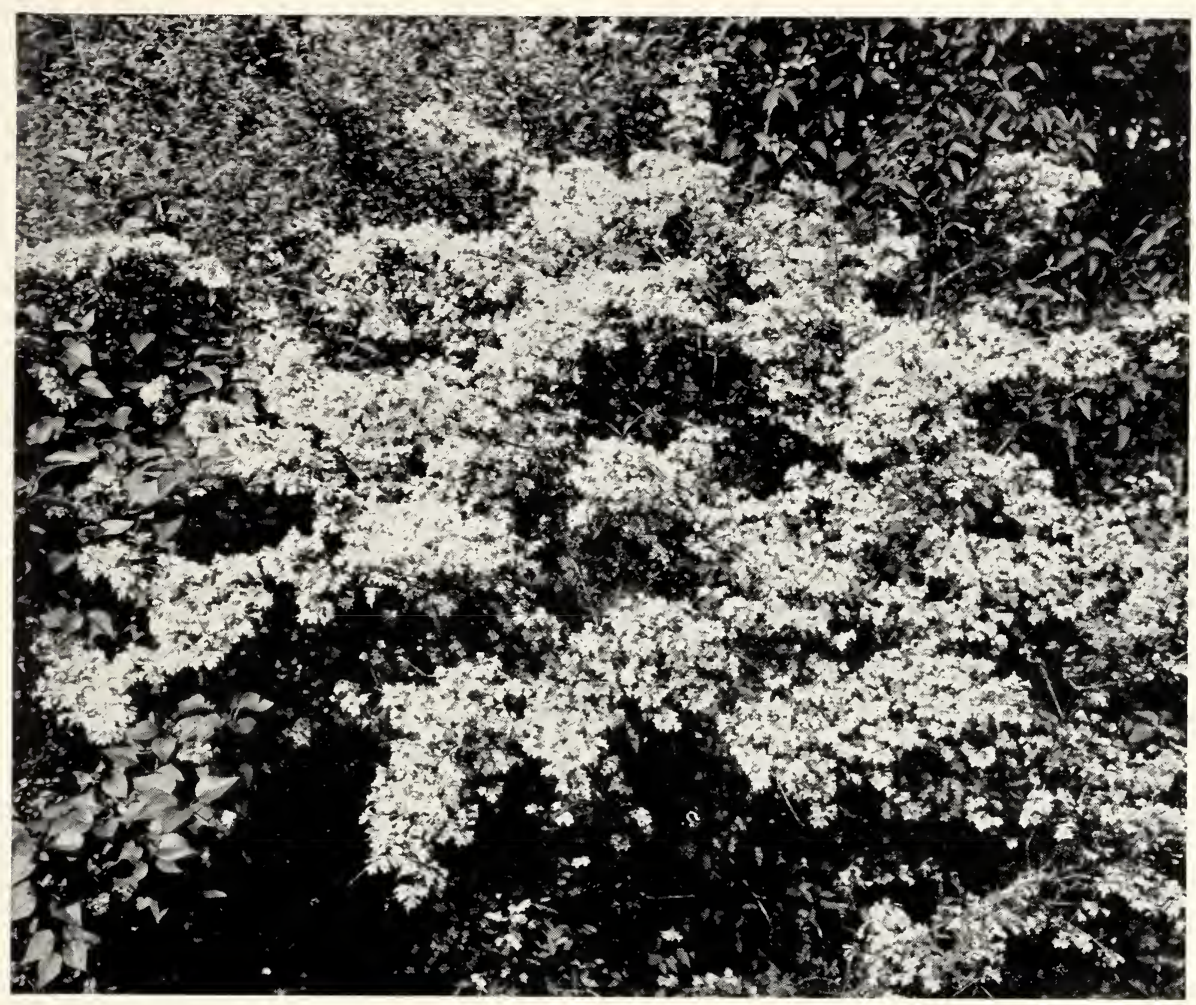

Kolkwitzia Amabilis (Beauty Bush).

SHOWY BORDER FORSYTHIA (Forsythia i. spectabilis). Freest flowering and the most beautiful.

3 to $4 \mathrm{ft}$..............\$1.00 each, $\$ 7.50$ per 10

2 to $3 \mathrm{ft} \ldots \ldots . . . . . . \$ .75$ each, $\$ 6.00$ per 10

WEEPING FORSYTHIA (Forsythia suspensa). Showers of sunshine announce Spring! Densely covered with glorious bell-shaped flowers on drooping branches.

2 to $3 \mathrm{ft}$..............\$. $\$ .00 \mathrm{each}, \$ 5.00$ per 10

18 to 24 in..........\$. $\$ 50$ each, $\$ 4.00$ per 10

FORTUNE FORSYTHIA (Forsythia s. fortunei). (S). Massed deep yellow blossoms, rich foliage turning purplish in Autumn.

4 to $5 \mathrm{ft} \ldots \ldots \ldots \ldots . . . . .90$ each, $\$ 7.50$ per 10

3 to $4 \mathrm{ft}$.............\$ .75 each, $\$ 6.00$ per 10

2 to $3 \mathrm{ft}$..............\$ $\$ .65$ each. $\$ 5.00$ per 10

GREENSTEM FORSYTHIA (Forsythia viridissima). (S). Blossoms later and less profusely, but has a more compact and deep green appearance.

2 to $3 \mathrm{ft}$.............. $\$ .65$ each, $\$ 5.50$ per 10
D W A R F ALDR (Fothergilla major). Hardy, ornamental shrub with long, showy spikes of white flowers, simple dull green leaves turning golden in Fall.

18 to 24 in...... $\$ 5.50$ each, $\$ 50.00$ per 10

SHRUB - ALTHEA (Hibiscus syriacus). Hardy upright growing shrub with profuse pink, white and violet flowers in late July and August. A splendid investment.
3 to $4 \mathrm{ft}$
$\$ .75$ each, $\$ 6.50$ per 10

2 to $3 \mathrm{ft}$.

$\$ .60$ each, $\$ 5.50$ per 10

\section{Double Red Double Purple}

Double White Double Pink

Double Blush Pink

SNOWHILL HYDRANGEA (Hydrangea arborescens grandiflora). Large clusters of snowwhite blossoms on graceful branches. Very hardy, blooms nearly all the Summer.

4 to $5 \mathrm{ft} \ldots \ldots \ldots . \$ 1.10$ each, $\$ 10.00$ per 10
3 to $4 \mathrm{ft} \ldots \ldots \ldots . \$ .90$ each, $\$ 8.00$ per 10
2 to $3 \mathrm{ft} \ldots \ldots \ldots . \$ .75$ each, $\$ 6.50$ per 10




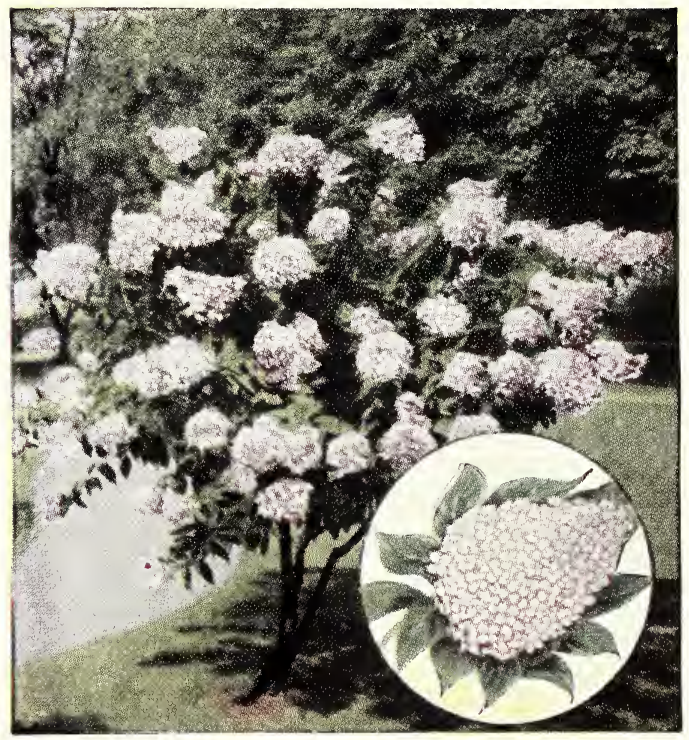

Hydrangea Paniculata.

PANICLED HYDRANGEA (Hydrangea paniculata). Tall, upright with dark green foliage, long white clusters of flowers in August.
2 to $3 \mathrm{ft}$..
$\$ .80$ each, $\$ 6.50$ per 10

18 to 24 in

$\$ .60$ each, $\$ 5.00$ per 10

HYDRANGEA PEEGEE (Hydrangea p. grandiflora). (S). Large size with a remarkable change in the huge blossoms from white to rose or bronze with age.

3 to $4 \mathrm{ft}$.............\$ $\$ 90$ each, $\$ 7.50$ per 10

2 to $3 \mathrm{ft}$.............\$ .65 each, $\$ 5.50$ per 10

18 to 24 in.......... \$ .60 each, $\$ 5.00$ per 10

S I L V E R - L E A V E D HYDRANGEA (Hydrangea radiata). Flat corymbs of white flowers, large heart-shaped, silver lined leaves make this a fine specimen shrub.

18 to 24 in

$\$ .50$ each, $\$ 4.50$ per 10

ST. JOHNSWORT (Hypericum densiflorum). Upright growing shrub with corymbs of bright yellow flowers from July to September.

2 to $3 \mathrm{ft}$............. $\$ 90$ earh, $\$ 8.00$ per 10 18 to 24 in..........\$ .65 each $\$ 5.50$ per 10

COMMON WINTERBERRY (Ilex verticillata). (S). Form of Holly, with small June flowers. Foliage darkly lustrous and exceedingly ornamental with sparkling masses of crimson fruit. Best in moist soil.

2 to $3 \mathrm{ft}$.......... $\$ 1.00$ each, $\$ 8.50$ per 10

18 to 24 in..........\$ $\$ .75$ each, $\$ 6.50$ per 10
KERRIA (Kerria japonica). Exquisitely slender and graceful, with single yellow blossoms throughout Summer.

2 to $3 \mathrm{ft} . . . . \$ .90$ each, $\$ 8.00$ per 10 18 to 24 in. $\$ .75$ each, $\$ 6.00$ per 10

DOUBLE KERRIA (Kerria j. florepleno). Like the above with double orange blossoms. Truly lovely.
2 to $3 \mathrm{ft}$...... $\$ 1.00$ each

18 to 24 in. $\$ .75 \mathrm{each}$

BEAUTY B U S H (Kolkwitzia amabilis). Something new and fascinating, arching branches with clusters of bell like flowers of pink, orange veined; buds of deep pink, charming coloration. This is the Arnold Arboretum's choicest new introduction.

4 to $5 \mathrm{ft}$. specimen, B\&B. $\$ 15.00$ each 18 to 24 in.... $\$ 2.00$ each, $\$ 18.00$ per 10 15 to 18 in.... $\$ 1.50$ each, $\$ 12.50$ per 10

AMUR PRIVET (Ligustrum amurense). (S). Excellent screen or hedge, grows tall, with white lilaclike flowers. Hardy.

$\begin{array}{llllll}6 & & \text { Each. } & \text { Per } 10 . & \text { Per } 100 . \\ 5 & \text { to } 6 \mathrm{ft} & \$ 1.00 & \$ 9.00 & \ldots \ldots . . \\ 3 \text { to } 4 \mathrm{ft} & \$ .90 & \$ 6.00 & \$ 45.00 \\ & \$ .60 & \$ 3.50 & \$ 24.00\end{array}$

IBOTA PRIVET (Ligustrum ibota). (S). For Northern climates, graceful, spreading with white, fragrant flowers and black berries. An excellent hedge plant. Each. Per 10 . Per 100. 3 to $4 \mathrm{ft} \ldots \ldots \ldots \ldots . . . \$ .50 \quad \$ 4.50 \quad \$ 27.00$

2 to $3 \mathrm{ft} \ldots \ldots \ldots . . . \$ 40 \quad \$ 3.00 \quad \$ 18.00$

REGAL PRIVET (Ligustrum i. regelianum). (S). Compact, spreading, exceptionally hardy, and has a wealth of blueblack berries.

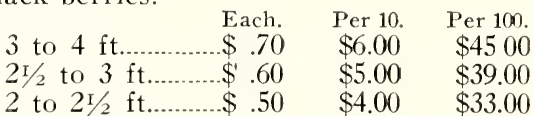

CALIFORNIA PRIVET (Ligustrum ovalifolium). (S). Upright, with glossy green foliage. Good hedge plant.

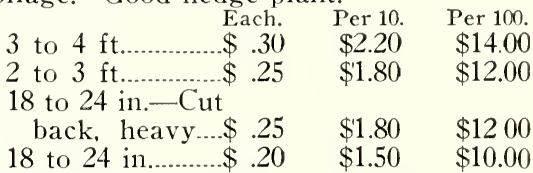

EUROPEAN PRIVET (Ligustrum vulgare). Tall, spreading, very hardy. White flowers against a background of graygreen foliage, followed by clusters of black berries.

$\begin{array}{llll}2 \text { to } 3 \mathrm{ft} \ldots \ldots \ldots \ldots . . . & \$ .40 & \$ 3.00 & \$ 27.00\end{array}$


W I N T E R HONEYSUCKLE (Lonicera fragrantissima). (B). Very early sweetscented white flowers. Almost evergreen foliage. 3 to $4 \mathrm{ft}$.. 90 each, $\$ 7.50$ per 10

MORROW HONEYSUCKLE (Lonicera morrowi). (BS). Pendulous branching, cream-white flowers deliciously fragrant; red fruit remaining all Fall.

3 to $4 \mathrm{ft}$............ .60 each, $\$ 5.00$ per 10

2 to $3 \mathrm{ft} \ldots \ldots .50$ each, $\$ 4.50$ per 10

MANCHURIAN HONEYSUCKLE (Lonicera ruprechtiana). (B). Yellow blossoms, fruit coral, decorative.

3 to $4 \mathrm{ft} \ldots \ldots \ldots \ldots \ldots . . . . \$ .60$ each, $\$ 5.00$ per 10

2 to $3 \mathrm{ft}$........... \$ 50 each, $\$ 4.50$ per 10

TATARIAN HONEYSUCKLE (Lonicera tatarica). (BS). Tall; pink flowers in early Spring, red fruit which attracts birds to feast.

3 to $4 \mathrm{ft}$........... \$ 60 each, $\$ 4.50$ per 10 2 to $3 \mathrm{ft} \ldots \ldots \ldots \ldots$...... $\$ 50$ each, $\$ 400$ per 10

WHITE TATARIAN HONEYSUCKLE

(Lonicera t. alba). (BS). White, dainty blossoms, and later red fruit.

3 to $4 \mathrm{ft}$............. $\$ .60$ each, $\$ 5.00$ per 10

2 to $3 \mathrm{ft} \ldots \ldots \ldots$ \$ .50 each, $\$ 4.00$ per 10

SWEET MOCKORANGE (Philadelphus coronarius). (S). Always alluringly lovely with waxy, white, fragrant flowers. Useful for cut flowers and background because of its verdant foliage.

3 to $4 \mathrm{ft}$............. $\$ .60$ each, $\$ 4.50$ per 10 2 to $3 \mathrm{ft}$............. $\$ .50$ each, $\$ 400$ per 10
GOLDEN MOCKORANGE (Philadelphus c. aureus). Dwarf, compact, with golden leaves and white blossoms. Excellent for low border shrub.

15 to 18 in.......... \$ .75 each, $\$ 7.00$ per 10 GORDON MOCKORANGE (Philadelphus gordonianus). (S). Late blossoming, white with gray-brown branches.

+ to $5 \mathrm{ft} \ldots \ldots . .75$ each, $\$ 6.50$ per 10 BIG SCENTLESS M O C K O R A N G E (Philadelphus grandiflorus). (S). Very large white flowers; rapid grower.
6 to $7 \mathrm{ft}$.
$\$ 1.00$ each
4 to $5 \mathrm{ft}$.
$\$ .75$ each, $\$ 5.00$ per 10
3 to $4 \mathrm{ft}$.
$\$ .60$ each, $\$ 4.00$ per 10

\section{HYBRID MOCKORANGE}

This group is the result of years of experiment by the famous Lemoine of France. That he has won complete success is evident because of the growing popularity of the shrubs.

Avalanche. Literally a Iandslide of white blossoms all along the drooping branches. 2 to $3 \mathrm{ft}$..............\$ .75 each, $\$ 6.00$ per 10

Brachybotrys. This long stemmed hybrid is covered with pure white flowers.

4 to $5 \mathrm{ft}$..........\$2.00 each, $\$ 18.00$ per 10 3 to $4 \mathrm{ft} \ldots \ldots \ldots \ldots . . \$ 1.50$ each, $\$ 14.00$ per 10

Glacier. Double rich creamy flowers produced in thick clusters of five to seven blooms.

18 to 24 in.......... $\$ .85$ each, $\$ 8.00$ per 10

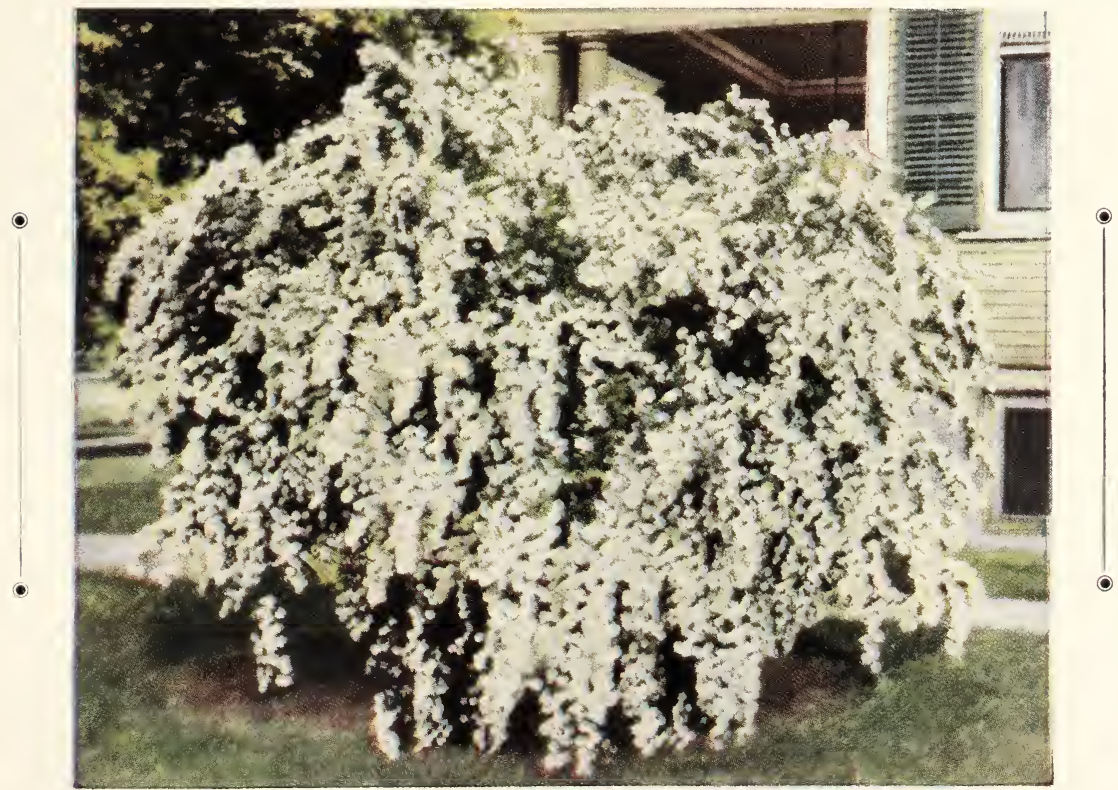

Spirea Van Houtte. 
Lemoine. Upright, with pure white, fragrant blossoms in June.

2 to $3 \mathrm{ft}$..............\$ .75 each, $\$ 6.50$ per 10

Mont Blanc. Dwarf sort with large, delightfully fragrant flowers.

2 to $3 \mathrm{ft}$............. $\$ .75$ each, $\$ 6.00$ per 10 18 to 24 in.......... $\$ .65$ each, $\$ 5.50$ per 10

V i rgina 1. The height of development. Snowy white, very large, double blossoms which continue to grow all Summer and even the Fall. This is a perfect joy though not as fragrant as the old-time "coronarius."

18 to 24 in

$\$ .80$ each, $\$ 7.00$ per 10

ILLINOIS NINEBARK (Physocarpus intermedius). (S). A prolific grower, tall, golden leaves.

3 to $4 \mathrm{ft} \ldots \ldots \ldots \ldots . . . . \ldots$ each, $\$ 6.50$ per 10

2 to $3 \mathrm{ft}$.............\$ $\$ .60$ each, $\$ 5.00$ per 10

C O M O N NINEBARK (Physocarpus opulifolius). (S). Sturdy shrub with bark hanging by shreds along stems upon which white flowers grow. An interesting effect.

4 to $5 \mathrm{ft}$.

$\$ .60$ each, $\$ 5.00$ per 10

3 to $4 \mathrm{ft} \ldots \ldots \ldots \ldots . . \$ .50$ each, $\$ 4.00$ per 10

DOUBLE PINKFLOWERING ALMOND

(Prunus glandulosa albiplena). Charming pink clusters on drooping branches in early Spring.

2 to $3 \mathrm{ft}$.............\$1.00 each, $\$ 8.00$ per 10

D O U B E WHITEFLOWERING ALMOND (Prunus glandulosa sinensis). May time brings an abundance of full, white flowers.

2 to $3 \mathrm{ft} \ldots \ldots \ldots \ldots . . \$ 1.00$ each, $\$ 8.00$ per 10

NANKING CHERRY (Prunus tomentosa). An exceptionally fine possession. Has a profusion of light pink blossoms, followed by delicious edible red fruit. Perfectly hardy anywhere.

3 to $4 \mathrm{ft} \ldots \ldots \ldots \ldots$....... $\$ .90$ each, $\$ 7.50$ per 10

2 to $3 \mathrm{ft} \ldots \ldots \ldots \ldots . . . . . . \$$ each, $\$ 5.00$ per 10

FLOWERING PLUM (Prunus triloba). Another joy. Delicate, double pink blossoms set on gracefully pendulous branches. Hardy.

2 to $3 \mathrm{ft} \ldots \ldots \ldots \ldots . . \$ 55$ each, $\$ 7.50$ per 10

JETBEAD (Rhodotypos kerrioides). (S). Waxy white flowers followed by black shiny berries.

18 to 24 in........ \$ .65 each, $\$ 5.00$ per 10

FRAGRANT SUMAC (Rhus canadensis).

(S). Low spreading, fragrant leaves. Yellow flowers.

2 to $3 \mathrm{ft} \ldots \ldots \ldots \ldots$....... $\$ 1.00$ each, $\$ 9.00$ per 10

18 to 24 in ......... \$.90 each. $\$ 7.50$ per 10

COMMON SMOKETREE (Rhus cotinus).

A mist of pale purple blossoms make this

a fascinating addition to a home lawn.

3 to $4 \mathrm{ft}$........ \$1.25 each, $\$ 10.00$ per 10
HUGONIS ROSE (Rosa hugonis). The charm of the yellow rose is at its best in this shrub, with its long garlands of single $2 \mathrm{I} / 2$ inch blossoms.

4 years.............\$2.00 each, $\$ 18.00$ per 10 3 years ............\$1.50 each, $\$ 13.50$ per 10

RUGOSA ROSE (Rosa rugosa). (BS). Blooms profusely. Red single roses followed by red fruit. Hardy at seashore, makes beautiful hedge.

18 to 24 in.......... $\$ .50$ each, $\$ 4.50$ per 10 For Hybrid Rugosa see Roses.

PRAIRIE ROSE (Rosa setigera). (S). Fond of trailing over stones or trellis and spreading joy with its exquisite deep rose-colored blossoms.

2 to $3 \mathrm{ft}$............ $\$ .50$ each, $\$ 4.00$ per 10 S C O T C H ROSE (Rosa spinosissima). Bristle covered branches and solitary white or yellow flowers.

2 to $3 \mathrm{ft} \ldots \ldots \ldots . . \$ 1.25$ each, $\$ 10.00$ per 10

ALTAI ROSE (Rosa s. altaica). Larger, more vigorous species than the above. The flowers are white.

2 to $3 \mathrm{ft}$...........\$1.75 each, $\$ 16.00$ per 10 WICHURIAN ROSE (Rosa wichuriana). (S). A creeper, making a close covering of glossy foliage, and in the late Summer fragrant clusters of white flowers.

2 years ............. \$ 60 each, $\$ 4.50$ per 10

AMERICAN ELDER (Sambucus canadensis). (S). Tall shrub with masses of dainty white blossoms.

2 to $3 \mathrm{ft} \ldots \ldots \ldots \ldots$ \$ $\$ .50$ each, $\$ 4.00$ per 10

CUTLEAF EUROPEAN ELDER (Sambubus nigra laciniata). (S). Attractive with panicles of yellowish white flowers followed by scarlet fruit.

4 to $5 \mathrm{ft} \ldots \ldots \ldots \ldots . . \$ 1.00$ each, $\$ 9.00$ per 10

3 to $4 \mathrm{ft} \ldots \ldots \ldots \ldots . . . \$$...... $\$ 5$ each, $\$ 6.00$ per 10

2 to $3 \mathrm{ft} . \ldots \ldots \ldots . . . . . \$ .60$ each, $\$ 5.50$ per 10

GARLAND SPIREA (Spiraea arguta). (S). An early bower of clustered white flowers.

3 to $4 \mathrm{ft} \ldots \ldots \ldots \ldots . . \$$ each, $\$ 5.50$ per 10

BUMALDA SPIREA (Spiraea bumalda). (S). Spreading low bush with dark foliage relieved by corymbs of light pink flowers in May and all during Summer.

18 to 24 in........\$. $\$ .60$ each, $\$ 5.00$ per 10

15 to $18 \mathrm{in......... \$ \$ .50} \mathrm{each,} \$ 4.00$ per 10

ANTHONY WATERER SPIREA (Spiraea b. anthony waterer). (S). Dwarf form with deep rose-colored corymbs, blossoming the whole season.

18 to 24 in........ $\$ .50$ each, $\$ 4.50$ per 10

FROEBEL SPIREA (Spiraea b. froebeli). (S). A trifle taller than the above. Bronzered foliage in Spring and Fall. Reddish pink corymbs in July and August.

2 to $3 \mathrm{ft} \ldots \ldots \ldots . . \$$ each, $\$ 4.50$ per 10 18 to 24 in.........\$. .50 each, $\$ 4.00$ per 10 
DOUGLAS SPIREA (Spiraea douglasi).

(S). Grows upright 7 feet, reddish brown branches. Narrow oblong leaves, bearing beautiful deep rose colored flowers in July.

3 to $4 \mathrm{ft}$.

$\$ .60$ each, $\$ 5.50$ per 10

2 to $3 \mathrm{ft} \ldots \ldots \ldots \ldots . . . .50$ each, $\$ 4.50$ per 10

WHITE JAPANESE SPIREA (Spiraea japonica ovalifolia) (callosa alba). Symmetrical, dwarf form suitable for borders or hedges.

15 to 18 in.........\$ $\$ 40$ each, $\$ 3.50$ per 10

BRIDALWREATH (Spiraea prunifolia).

Tiny double white flowers massed along the graceful stems in May.

3 to $4 \mathrm{ft} \ldots \ldots \ldots . . . . \$ 5$ each, $\$ 650$ per 10

2 to $3 \mathrm{ft} \ldots \ldots \ldots$....... $\$ .5$ each, $\$ 5.50$ per 10

T H U N B E R G SPIREA (Spiraea thunbergi). Recommended highly for its lovely April flowers.

5 to $6 \mathrm{ft} \ldots \ldots \ldots \ldots . . \$ 1.50$ each, $\$ 12.50$ per 10
4 to $5 \mathrm{ft} \ldots \ldots \ldots \ldots$ each, $\$ 10.00$ per 10
3 to $4 \mathrm{ft} . \ldots \ldots \ldots . . \$ 90 \mathrm{each}, \$ 7.50$ per 10

2 to $3 \mathrm{ft}$............. $\$ .75$ each, $\$ 6.00$ per 10

KOREAN SPIREA (Spiraea trichocarpa). A new variety with arching branches and large clustered blooms.

2 to $3 \mathrm{ft}$...........\$1.25 each, $\$ 10.00$ per 10

18 to 24 in........\$1.00 each, $\$ 7.50$ per 10

VANHOUTTE SPIREA (Spiraea vanhouttei). (S). Unparalleled for graceful arching of branches and luxuriance of green foliage and white flowers.
4 to $5 \mathrm{ft}$.. $\$ .90$ each, $\$ 6.00$ per 10
3 to $4 \mathrm{ft}$. $\$ .75$ each, $\$ 5.00$ per 10
2 to $3 \mathrm{ft}$. $\$ .50$ each, $\$ 4.00$ per 10

CUTLEAF STEPHANANDRA (Stephanandra flexuosa). Leaves fern-like, pendant branches and masses of creamy white flowers. A delightful bit of delicacy.

2 to $3 \mathrm{ft} \ldots \ldots \ldots . . .60$ each, $\$ 5.00$ per 10

18 to 24 in........ \$ .50 each, $\$ 4.50$ per 10

S N O W B E R R Y (Symphoricarpos chenaulti). A lovely hybrid from the Arnold Arboretum, small red dotted fruit all Summer and Autumn. A unique possession.

2 to $3 \mathrm{ft} \ldots \ldots \ldots \ldots$..... $\$ 1.00$ each, $\$ 9.00$ per 10

18 to 24 in....... $\$ .75$ each, $\$ 6.50$ per 10

COMMON SNOWBERRY (Symphoricarpos racemosus). (S). Waxy white berries that hang all Winter.

3 to $4 \mathrm{ft}$............ $\$ .75$ each, $\$ 6.00$ per 10

2 to $3 \mathrm{ft} \ldots \ldots \ldots \ldots . . .60$ each, $\$ 4.50$ per 10

18 to 24 in......... \$ .50 each, $\$ 4.00$ per 10

CORALBERRY (Symphoricarpos v u lgaris). (S). Slender branched and covered with coral red berries in Autumn. Rapid in growth.

3 to $4 \mathrm{ft} \ldots \ldots \ldots . . \$ 60$ each, $\$ 4.50$ per 10
2 to $3 \mathrm{ft} \ldots \ldots \ldots \ldots \ldots$ e......... .50 each, $\$ 4.00$ per 10
CHINESE L I L A C (Syringa chinensis) (rothomagensis). One of the finest tall violet-blue varieties appearing in June.

3 to $4 \mathrm{ft} \ldots \ldots \ldots+.25$ each, $\$ 11.00$ per 10

2 to $3 \mathrm{ft} \ldots \ldots \ldots \ldots$ \$ .90 each, $\$ 8.00$ per 10

LITTLELEAF LILAC (Syringa microphylla). The foliage of this exquisite plant expands early in April and remains until well into October. The flower clusters which are light heliotrope are produced on lateral buds and are so closely interwoven that the slender branches droos gracefully under their weight. Superbly fragrant. and frequently blooms a second time in Aug. and Sept. VERY RARE. 2 to $2 \mathrm{r} / 2 \mathrm{ft} \ldots \ldots . . . \$ 50$ each, $\$ 50.00$ per 10

C O M M O N LILAC (Syringa vulgaris). (S). Sturdy growth with profuse panicles of purplish flowers blossoming in May.

4 to $5 \mathrm{ft}$. $\$ 1.75$ each

3 to $4 \mathrm{ft} \ldots \ldots \ldots+\ldots 1.25$ each, $\$ 11.00$ per 10

2 to $3 \mathrm{ft} \ldots \ldots \ldots \ldots$..... $\$ 100$ each, $\$ 9.00$ per 10

COMMON WHITE LILAC (Syringa v. alba). (S). Exquisitely scented pure white blossoms.
2 to $3 \mathrm{ft}$
$\$ 1.00$ each, $\$ 9.00$ per 10
6 to $8 \mathrm{ft}$. Standard ................\$500 each
5 to $6 \mathrm{ft}$. Standard.
$\$ 4.00$ each

\section{HYBRID LILACS}

Too few of us appreciate the hybrid and improved varieties of Lilacs. Unlike the white and purple kinds long familiar to us. they bloom when very small plants, and can be kept in fairly limited space. It is a small garden that has no room for an assortment of these splendid Lilacs.

Ambroise Verschaffelt. Single white, tinged laelia pink.

18 to 24 in....... \$1.50 each, $\$ 1400$ per 10

Amoena. Single chinese violet, shading to tourmaline pink. Large and numerous clusters.

2 to $3 \mathrm{ft} \ldots \ldots 1.75$ each, $\$ 16.00$ per 10
18 to 24 in.....\$150 each, $\$ 1400$ per 10

Charles the Tenth. Beautiful clusters of single reddish-purple flowers.

2 to $3 \mathrm{ft} \ldots \ldots \ldots \ldots 1.50$ each, $\$ 14.00$ per 10

Dr. von Regel. Compact clusters pale laelia pink with margin of white. Single. 18 to 24 in......\$1.50 each, $\$ 14.00$ per 10

Giant. Large single clusters, shading from purple to violet. Very choice.

18 to 24 in ....... $\$ 1.50$ each, $\$ 14.00$ per 10

Michel Buchner. Large double pale-lilac flowers; dwarf.

2 to $3 \mathrm{ft} \ldots \ldots 1.50$ each, $\$ 14.00$ per 10

18 to 24 in......................... $\$ 1.25$ each

Mme. Casimir Perier. Double cream white. 18 to 24 in........\$1.25 each, $\$ 10.00$ per 10 
Mme. Lemoine. Large double white; immense clusters.

2 to $3 \mathrm{ft}$............\$1.25 each, $\$ 11.00$ per 10 18 to $24 \mathrm{in} . . . . . \$ 1.00$ each, $\$ 9.00$ per 10

Mme. Moser. B e a $u$ t if ul single white clusters.

2 to $3 \mathrm{ft} . \ldots \ldots \ldots . . \$ 1.50$ each, $\$ 14.00$ per 10

President Grevy. Pale blue panicles of exquisite beauty.

2 to $3 \mathrm{ft} . \ldots \ldots 1.50$ each, $\$ 14.00$ per 10

Senateur Volland. Double compact clusters tourmaline pink, shading to lilac.

2 to $3 \mathrm{ft} . \ldots \ldots \ldots . . \$ 1.75$ each, $\$ 16.00$ per 10

18 to 24 in...... $\$ 1.50$ each, $\$ 14.00$ per 10

Hybrid Lilacs. Mixed.

2 to $3 \mathrm{ft} \ldots \ldots . . . \quad \$ 85$ each, $\$ 7.50$ per 10

18 to 24 in......... \$ .65 each, $\$ 5.00$ per 10

HIGHBUSH BLUEBERRY (Vaccinium corymbosum). (S). A native of New England, with pink tinged white flowers and edible fruit. Has beautiful Fall foliage, almost scarlet.

3 to $4 \mathrm{ft}$..........\$2.00 each, $\$ 18.00$ per 10

2 to $3 \mathrm{ft} \ldots \ldots 125$ each, $\$ 11.00$ per 10

AMERICAN CRANBERRYBUSH (Viburnum americanum). (S). A ha rdy shrub attaining the height of 12 feet, bearing white flowers in June and loaded with gorgeous red fruit in Fall and Winter. Useful for jelly.

2 to $3 \mathrm{ft} \ldots \ldots . . . \$ 5$ each, $\$ 6.50$ per 10
F R A G R A N T VIBURNUM (Viburnum carlesi). Compact bushy growth, with pale rosy-pink Howers of exquisite fragrance.

18 to 24 in. $B \&$ B.... $\$ 3$ ea., $\$ 27.00$ per 10

12 to 18 in. B \& B...\$2 ea., $\$ 1800$ per 10

WITHE-ROD (Viburnum cassinoides. (S). Creamy white flowers followed by berries; first pink, then blue. Thrives in a moist soil as well as dry.

3 to $4 \mathrm{ft}$.......... $\$ 1.25$ each, $\$ 10.00$ per 10

2 to $3 \mathrm{ft} \ldots \ldots \ldots \ldots . . . . \$ 90$ each, $\$ 7.50$ per 10

ARROWWOOD (Virburnum dentatum). (S). Roughly heart-shaped leaves becoming richly red in Fall. White flowers followed by blue berries. A fine hedge plant.

$\begin{array}{ll}4 \text { to } 5 \mathrm{ft} \ldots & \$ 1.25 \text { each, } \$ 10.00 \text { per } 10 \\ 3 \text { to } 4 \mathrm{ft} \ldots & \$ .90 \text { each, } \$ 7.50 \text { per } 10 \\ 2 \text { to } 3 \mathrm{ft} \ldots & \$ .75 \text { each, } \$ 6.50 \text { per } 10\end{array}$

WAYFARING-TREE (Viburnum lantana) Robust growth, with clusters of white flowers in May, followed by red fruit which turns black in Autumn.

3 to $4 \mathrm{ft}$.......... $\$ 1.00$ each, $\$ 8.00$ per 10

NANNYBERRY (Viburnum le $\mathrm{ntag}$ o). Creamy white fragrant flowers, with bluish-black fruit.

4 to $5 \mathrm{ft}$.............\$1.00 each, $\$ 8.00$ per 10

3 to $4 \mathrm{ft}$............. \$ .75 each, $\$ 6.50$ per 10

2 to $3 \mathrm{ft} \ldots \quad \$ .65$ each, $\$ 5.50$ per 10

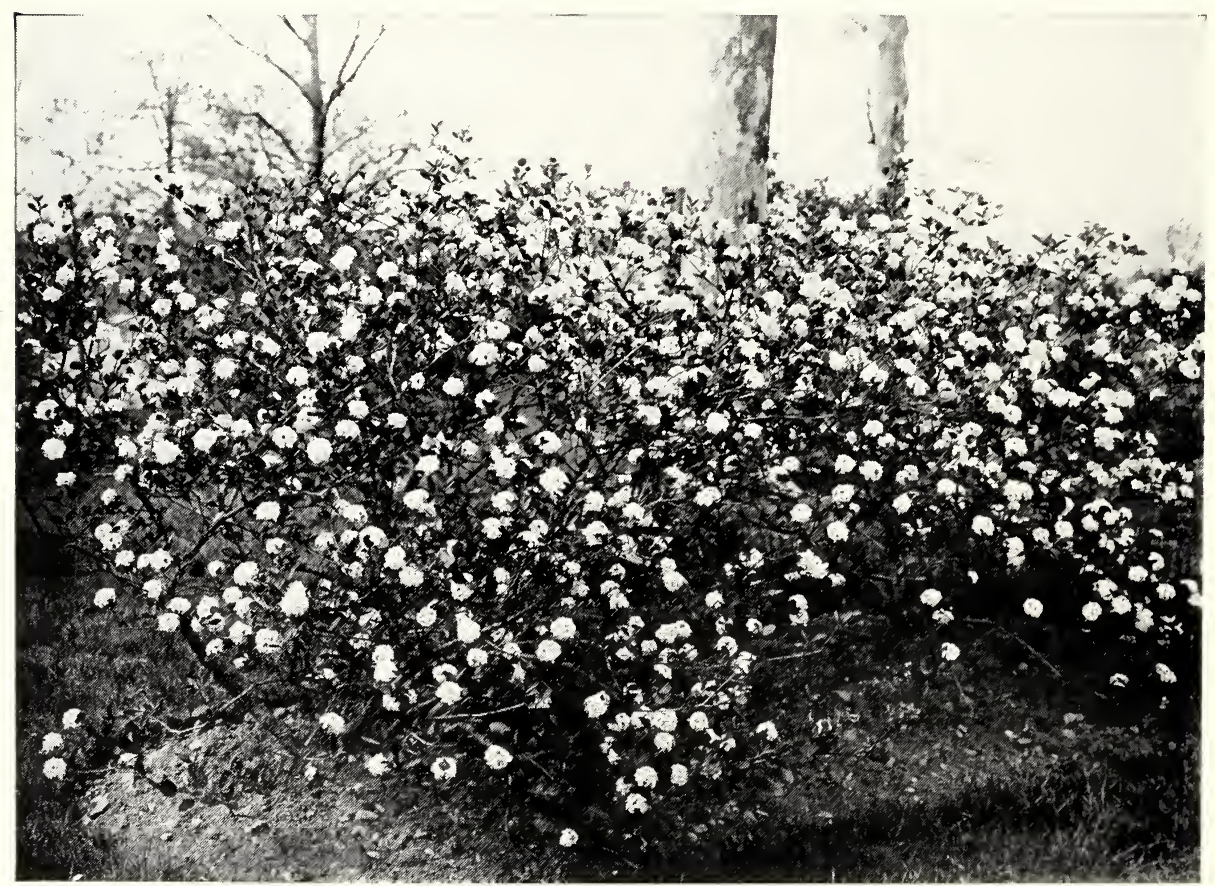

Viburnum Carlesi.

Five or more plants of one kind priced at the 10 rate. 
EUROPEAN CRANBERRYBUSH (Viburnum opulus). White flowers in panicles, and red berries which remain until early Winter.

2 to $3 \mathrm{ft} \ldots . . . . . . . . \$ . \$ 5$ each. $\$ 6.50$ per $1 \mathrm{C}$ 18 to 24 in.........\$ .65 each, $\$ 5.50$ per 10

COMMON SNOWBALL (Viburnum 0 sterile). Old-fashioned and delightful is this sturdy, hardy shrub with round clustered flowers.

2 to $3 \mathrm{ft} \ldots \ldots . . . . . . . \$$.... 5 each. $\$ 6.50$ per $1 \mathrm{C}$

DOUBLEFILE VIBURNUM (Viburnum tomentosum). Flat racemes of white flowers borne in great profusion on sturdy branches. An excellent variety.

2 to $3 \mathrm{ft} \ldots \ldots 1.00$ each. $\$ 8.00$ per 10

JAPANESE SNOWBALI (Viburnum t. plicatum). A sturdy type with rich foliage and large, globular heads of snowy whiteness.

18 to 27 in.

S $.75 \mathrm{each}$

CRIMSON WEIGELA (Weigela floribunda). Abounding in tubular flowers in a background of deep foliage.

2 to $3 \mathrm{ft} \ldots \ldots$........ .60 each, $\$ 5.50$ per 10
PINK WEIGELA (Weigela rosea). Large bell-shaped blossoms appearing profusely in June.

3 to 4 it............ .75 each. $\$ 6.50$ per 10 2 to 3 it.............. .60 each. $\$ 5.00$ per 10

VARIEGATED WEIGELA (Weigela r variegata). Dwarf leaves, broadly margined in white; white flowers.

2 to 3 it........ $\$ .75$ each, $\$ 6.00$ per 10

\section{HYBRID VARIETIES}

Snow Weigela (Weigela candida). Vigorous growth with unusually large white Howers.

2 to 3 it......... \$ 50 each, $\$ 4.50$ per 10

Desbois Weigela (Weigela desboisi). Richly hued in deep rose. A lovely shrub. though smaller in blossom.

2 to 3 it........... \$ 60 each, $\$ 5.50$ per 10

Eva Rathke (Weigela Eva Rathke). Low growing, with dark brownish red flowers. 2 to 3 it........ .75 each, $\$ 6.50$ per 10

Yellowroot (Zanthorhiza apiifolia). Dwari shrub valuable as ground cover. Soft, plum-colored flowers in misty profusion. Hardy. 12 to 15 in ................. .50 each

\section{Anniversary Corner Shrub Collections}

Splendid results will be given by these attractively priced groupings.

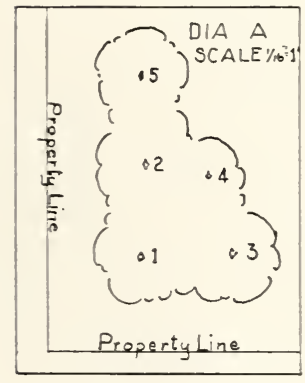

Anniversary Collection No. 1

Diagram A

Plant- No. of

ing Key Plants

11 Viburnum lentago.

$18-24^{\prime \prime}$

1 Vaccinium corymbosum, $2-3^{\prime}$

1 Ligustrum regelianum, $2-3^{\prime}$

1 Spirea vanhouttei. 2-3'

1 Symphoricarpos chenaulti, 18-2t"

5 Splendid Shrubs

Anniversary Special Offer.

\section{$\$ 2.50$}

Regular Price, $\$ 3.60$

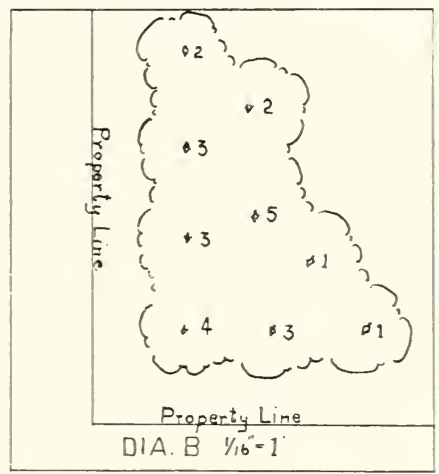

Anniversary Collection No. 2

Diagram A

l'lant- No. of

ing Key Plants

$\begin{array}{lll}1 & 1 & \text { Hydrangea P. G., 2-3' } \\ 2 & 1 & \text { Lonicera tatarica alba, 2-3' } \\ 3 & 1 & \text { Philadelphus coronarius, 2-3' } \\ 4 & 1 & \text { Forsythia sus. fortunei, 2-3' } \\ 5 & 1 & \text { Cydonia japonica, 18-24" } \\ & \text { 5 Exceptional Plants }\end{array}$

Anniversary Special Offer .

Regular Price, $\$ 3.00$
Anniversary Collection No. 3 Diagram B Plant- No. of ing Key Plants

12 Spirea vanhouttei, 2-3'

22 Symphoricarpos chenaulti.

$$
\text { 18-2t" }
$$

33 Ligustrum regelianum, 2-3'

+1 Tiburnum lentago, 18-2t"

51 Spirea douglasi. 2-3'

9 Fine Shrubs-a larger. more effective grouping of Collection No. 1. 


\section{Climbing and Trailing Plants}

I IKE the miraculous change wrought by the wave of the magic wand, graceful hang-

ing or climbing vines can bring beauty to places, plain, ugly or worn.

Abbreviations: Suitable for Rock Gardens (R); Suitable for Sea Shore (S); Attracts Birds (B).

BOWER ACTINIDIA (Actinidia arguta).

A sturdy Japanese vine with large leaves, and white purple centered flowers.

2 years

$\$ 1.00$ each, $\$ 8.50$ per 10

VIRGINIA CREEPER (Ampelopsis quinquefolia). (S). A prolific grower to any height. Splendid for covering walls, fences and old stumps. Deep crimson foliage in the Fall.

4 years …........ $\$ .75$ each, $\$ 6.00$ per 10

JAPANESE CREEPER or BOSTON IVY (Ampelopsis tricuspidata). Even more vigorous than the above. Immune to insects, disease and smoke.

4 inch Pots........\$ .75 each, $\$ 7.00$ per 10

3 inch Pots........\$ .60 each, $\$ 5.50$ per 10

DUTCHMANS-PIPE (A ristolochia sipho) A fine screen, large leaves with brownish pipe shaped flowers in the Spring.

4 years........... $\$ 1.50$ each, $\$ 14.00$ per 10

TRUMPETCREEPER (Bignonia $\mathrm{r}$ a di cans). Tall growing, twining vine bearing orange flowers in mid-Summer.

3 years $\$ .50$ each, $\$ 4.00$ per 10

ORIENTAL BITTERSWEET (Celastrus orbiculatus). Round leaves, vigorous climber with orange berries bursting in the Autumn disclosing flame-colored centers.

3 years _............ $\$$ each, $\$ 6.00$ per 10

AMERICAN BITTERSWEET (Celastrus scandens). A charming rambler with lovely, shiny, roundish leaves and bright orange berries on display all Winter.

3 years.......... \$ .90 each, $\$ 8.00$ per 10

2 years ............... \$ .75 each, $\$ 6.00$ per 10

SWEET AUTUMN CLEMATIS (Clematis paniculata). (S). Delicate white blossoms like a bit of old lace; this graceful vine climbs over trellis and porches.

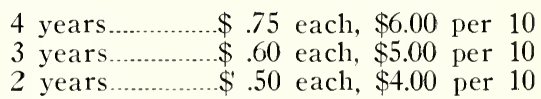

ENGLISH IVY (Hedera helix). The always satisfactory climber for brick or stone walls; dark, glossy, white veined leaves.

3 in. Pots _........ \$.60 each, $\$ 5.50$ per 10

YELLOWNET JAPANESE H O N E Y

SUCKLE (Lonicera japonica aureoreticulata). Leaves of variegated gold and green, slow growth, but sturdy and handsome.

3 years .............. \$ .50 each, $\$ 4.00$ per 10

H A L L JAPANESE HONEYSUCKLE (Lonicera j. halliana). Deliciously fragrant blossoms of white, turning to buff; dark, glossy green foliage.

3 years ….... $\$ .50$ each, $\$ 4.00$ per 10

TRUMPET HONEYSUCKLE (Lonicera sempervirens). Glorious blossoms in scarlet from May until September. A choice possession.

3 years ............ $\$ .50$ each, $\$ 3.50$ per 10

CHINESE MATRIMONY-VINE (Lycium chinense). Charming against low walls and over rocks. A profusion of vivid purple, star-shaped flowers, changing to scarlet berries an inch in length. These against rich green foliage is most effective.

3 years _.......... $\$ .50$ each, $\$ 4.00$ per 10

CHINESE WISTERIA (Wisteria sinensis). One of nature's most graceful showers of loveliness. This variety has light green foliage and violet-blue flowers of pea-shape in drooping clusters.

4 years ............ $\$ 1.00$ each, $\$ 8.00$ per 10

3 years.............. $\$ .75$ each, $\$ 6.00$ per 10

2 years ................ $\$ .60$ each, $\$ 5.00$ per 10

SHRUBS, by F. F. Rockwell. Here is brief but complete and usable information on the best ways to improve the beauty and value of your home with Shrubs. Tells what to select for different combinations and effects, and how to plant, water, mulch, prune, and care for Shrubs. 49 illustrations, 76 pages.

Sent free as a premium for order of $\$ 10.00$ worth of Shrubs from this catalog. 


\section{Anniversary Shrub Entrance Collection}

For those wishing an attractive Flowering Shrub Collection for the entrance to the grounds, one of these will be ideal.

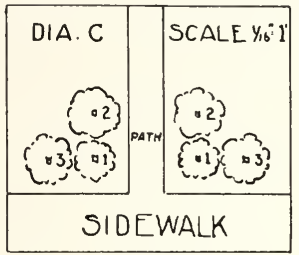

Anniversary Collection No. 5

Plant- No. of

ing Key Plants

$\begin{array}{lll}1 & 2 & \text { Azalea canescens, 15-18" } \\ 2 & 2 & \text { Deutzia lemoinei, 18-24" } \\ 3 & 2 & \text { Spirea bumalda, 18-24" }\end{array}$ Diagram C

6 Exceptional Shrubs Anniversary Special Offer ...\$5.25

Regular Price, $\$ 6.70$
Anniversary Collection No. 4 Diagram C Plant- No. of
ing Key Plants

12 Symphoricarpos chenaulti,

22 Spirea douglasi, 2-3'

32 Symphoricarpos racemosus, 18-24"

6 Hardy Shrubs

Anniversary Special Offer ...\$2.95

Regular Price, $\$ 4.00$

Anniversary Collection No. 6

Plant- No. of Diagram C ing Key Plants

12 Spirea japonica ovalifolia, $12-15^{\prime \prime}$

22 Weigela floribunda, 2-3'

32 Forsythia intermedia, 18-24"

\section{Good Plants}

Anniversary Special Offer ...\$2.25

Regular Price, $\$ 2.90$

\section{Anniversary Evergreen Entrance Collection}

One of these combinations will add dignity and charm to the entrance of your grounds.

Anniversary Collection No. 7

Plant. No. of

ing Key Plants

$$
\text { Diagram D }
$$

1

2 Pinus mughus, 15-18"

4 Taxus cuspidata, 15-18"

6 Hardy, distinctive Evergreens -A fine Entrance Collection that will always be admired.

Anniversary Special Offer . $\$ 17.00$

Regular Price, $\$ 22.00$

Anniversary Collection No. 8 Diagram D

Plant- No. of ing Key Plants

12 Juniperus pfitzeriana, 18-24"

24 'Thuja woodwardi, 2-2 $1 / 2^{\prime}$

6 Large, hardy plants.

Anniversary Special Offer . \$16.75 Regular Price, $\$ 21.00$

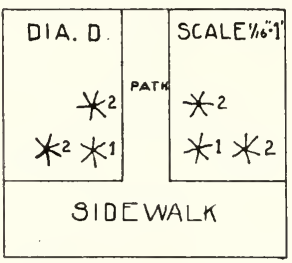

Anniversary Collection No. 9 Diagram D

Plant- No. of

ing Key Plants

12 Juniperus ex. stricta, 15-18"

24 Juniperus sabina, 15-18"

6 Fine Plants. A good selection. Anniversary Special Offer . $\$ 14.50$ Regular Price, $\$ 18.00$ 


\section{Anniversary Corner Evergreen Collection}

For all-year-round effects, use one of these splendid Anniversary Groupings. Note the sizes which assure immediate effect.

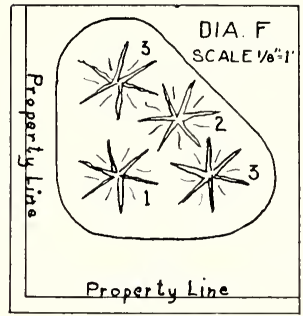

Anniversary Collection No. 11 Diagram F

Plant- No. of ing Key Plants

11 Juniperus hibernica, 21/2-3'

22 Juniperus sabina, 15-18"

31 Juniperus pfitzeriana, 18-24"

4 Fine Hardy Plants

Anniversary Special Offer . $\$ \mathbf{1 0 . 7 5}$ Regular Price, $\$ 13.50$

\section{Anniversary Collection No. 13}

\section{Diagram E}

$\begin{array}{cc}\text { Plant- } & \text { No. of } \\ \text { ing Key } & \text { Plants }\end{array}$

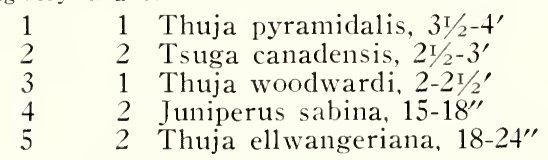

8 Beautiful Hardy Plants. There is no finer Corner Evergreen Selection.

\section{Anniversary Special Offer . \$24.75}

Regular Price, $\$ 30.50$
Anniversary Collection No. 10

Plant. No. of

Diagram $F$

ing Key Plants

11 Thuja wareana, $2 \mathrm{~T} / 2-3^{\prime}$

22 Thuja globosa, 18-24"

31 Juniperus sabina, 15-18"

4 Beautiful Hardy Evergreens Anniversary Special Offer. $\$ \mathbf{1 1 . 0 0}$

Regular Price, $\$ 14.00$

Anniversary Collection No. 12 Diagram E

Plant- No. of ing Key Plants

$\begin{array}{lll}1 & 1 & \text { Thuja occidentalis, 2-3' } \\ 2 & 2 & \text { Thuja wareana, 2-2 } \text { 2' }^{\prime} \\ 3 & 1 & \text { Thuja globosa, 18-24" } \\ 4 & 2 & \text { Thuja woodwardi, 15-18" } \\ 5 & 2 & \text { Juniperus sabina, 15-18" }\end{array}$

8 Hardy Evergreens-Will give a splendid effect.

Anniversary Special Offer . \$18.75

Regular Price, $\$ 23.50$

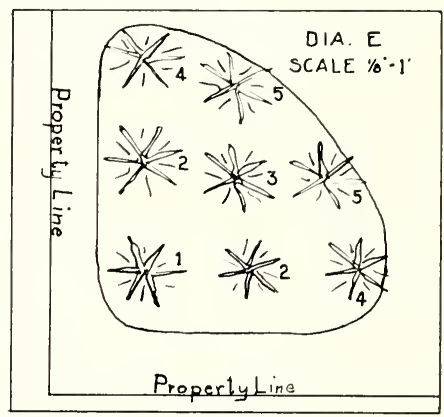

E vergreens For THE SMALL PLACE, by F. F. Rockwell. All the informaE tion you need to make the best use of evergreens is in this handy book, written by one who is himself a home owner and a garden maker. It tells the uses, characteristics, and types of small or dwarf evergreens, and details of their planting, transplanting, and general care. 67 illustrations, 84 pages.

Sent free as a premium for order of $\$ 10.00$ worth of

Evergreens from this catalog. 


\section{Rock Gardens}

T $\mathrm{HE}$ art of Rock Gardening is a special cult. It is the extreme in gardening and difficult. Special knowledge is needed both for constructing the garden and for choosing the plants to inhabit it. Yet, the fact that Rock Gardening is tremendously popular, proves that the game is not only fascinating but usually successful.

The garden will suggest the barren crags or lofty mountain tops, and you will plant, in carefully prepared crevices, all the delightful flora of Patagonia, Oregon, Finland, Japan, and the Alps.

If you are fortunate in having a place that is partially or completely shaded, you may build instead a Woodland Rock Garden. This is less difficult of achievement, and offers a much greater selection in plants certain to thrive. It will imitate the rocky, woodland areas harboring such plants as English Primrose and the Maidenhair Fern.

If possible, avoid any formality in constructing your Rock Garden. The arrangement must depend somewhat upon existing conditions, and the area to be used. Should you not have a proper background, this may be overcome by the use of trees, flowering shrubs, and a few evergreens. To make it still more interesting, a small Fountain or Bird Bath may be placed near the shade of the shrubs, and this will make an inviting place for the birds.

Rock plants, with ferv exceptions, are deep rooted and should have an ample supply of prepared soil, with provision for good drainage. Plants should be chosen which blossom at different intervals so as to prolong the blooming season. To make a proper mass, it is better to have not less than three plants of each variety.

Select rocks not less than one foot in diameter,-two feet is better,-rather broad in appearance. Use few, if any, small ones as they tend to produce an artificial effect. Place your rocks so you will have pockets of soil for the roots to penetrate, leaving room between them for the plants to grow and spread.

In this Guide we have marked with the letter (R) those plants suitable for Rock Gardens. We will gladly send selected lists to those interested in plants for special conditions, such as moist, shady, and dry hot places.

\section{Suggestions For Rock Garden Plants}

Gypsophila repens

Anemone sylvestris

Dianthus deltoides

Ceratostigma plumbaginoides

Primula polyanthus

Polemonium caeruleum

Dicentra eximea

Iberis s. Little Gem

Papaver nudicaule

Oenothera missouriensis

Ajuga genevensis

Hypericum repens

Lysimachia nummularia

Armeria maritima

Centaurea montana
Iris pumila cyanea

Aquilegia canadensis

Campanula alliariaefolia

Heuchera Perry's White

Linum flavum

Mertensia virginica

Polemonium repens

Iris alpine-Lobelia

Iris alpine-Orange Queen

Arabis alpina

Iberis gibraltarica

Aster alpinus

Callirhoe involucrata

Aquilegia caerulea

Dianthus alpinus 


\section{Suggestions for Constructing a Small Rock Garden Similar to Our Plan}

I. Assemble forty-five or fifty weathered rocks for the finished surface, and about twenty to be used in the foundation.

2. Prepare a mixture of four yards each of sharp sand, garden soil, and vegetable fibre. This should be thoroughly mixed together.

3. Place the foundation rocks in the center of the area to be used, leaving spaces between rocks of about one foot, and cover with the soil mixture.

4. Now place additional rocks on this area, separating, covering, and filling in between as before.

5. Ram the soil firmly between each rock as you proceed.

6. Continue as above until you have finally used the weathered rock for the finish, leaving exposed from one-third to one-half of rock surface.

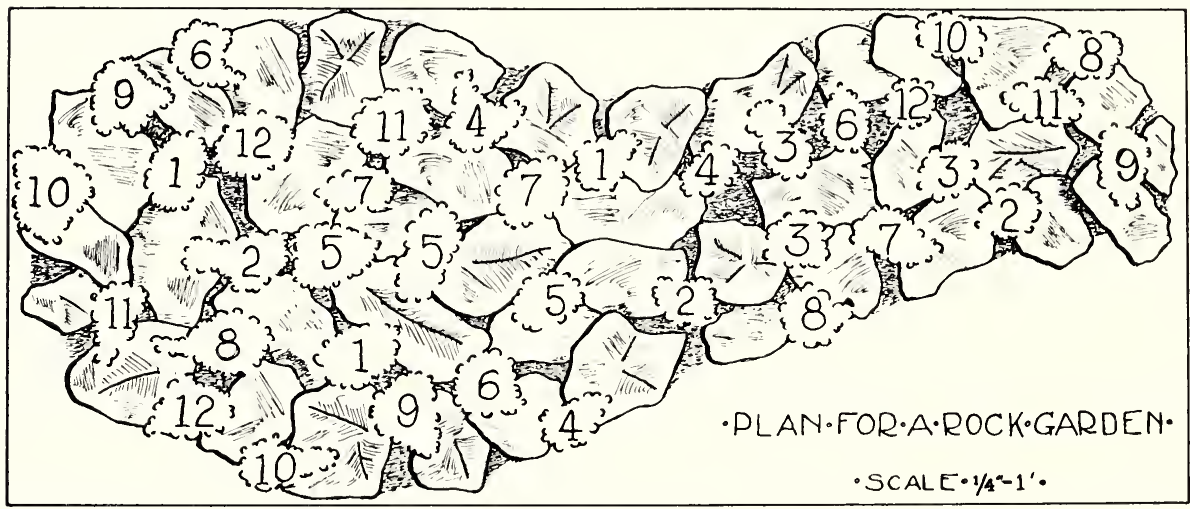

\section{Anniversary Rock Garden Collection}

For Above Plan

Anniversary Collection No. 17

Key No.

1 Phlox divaricata

2 Iberis sempervirens

3 Heuchera-Shirley Hybrids

4 Primula veris

5 Primula polyanthus

6 Thymus serpyllum coccineum Key No.

$\begin{aligned} 7 & \text { Veronica repens } \\ 8 & \text { Alyssum saxatile compactum } \\ 9 & \text { Viola c. Jersey Gem } \\ 10 & \text { Cerastium tomentosum } \\ 11 & \text { Cheiranthus allioni } \\ 12 & \text { Dianthus caesius }\end{aligned}$

36 Plants (3 of each)

Anniversary Special Offer .... \$8.75

Regular Price, $\$ 11.25$

R OCK GARDENS, by F. F. Rockwell. Shows just how you can build a rock garden $R$ yourself, on a small or large scale and at little expense. Describes the types of rock gardens, tells what soils, climates, and locations are best, how to construct, and what to plant for the effect you want. 31 illustrations, 86 pages.

Sent free as a premium for order of $\$ 10.00$ worth of Rock Garden Plants

from this catalog. See suggested lists on pages 23 and 35 . 


\section{Perennials}

ELOWER lovers know the delight of continuously blooming plants. Not only do PerF ennials blossom intermittently all Summer, but year after year they return with increased vigor.

There is charm in the old-fashioned Perennial Garden, in the tiny blossoms for borders, and enduring beauty in color and form of the more robust plants, indispensable in garden planting.

Abbreviations: Suitable for Rock Gardens (R); Suitable for Sea Shore (S); Attracts Birds (B). All Perennials, 30c each, $\$ 2.40$ per 10 , unless otherwise noted.

YARROW (Achillea).

ptarmica. "The Pearl." White; 2 ft.; July to October. $\$ .25$ each, $\$ 2.20$ per 10 .

p. Perry White. White; $2 \mathrm{ft}$; June to September.

tomentosa (Wooly Yarrow). (R). Bright yellow; 5 to 6 in.; July to September.

MONKSHOOD (Aconitum).

autumnale (Autumn Monkshood). Dark blue; 4 to $5 \mathrm{ft}$.; September to frost. $\$ .50$ each, $\$ 4.00$ per 10 .

fischeri (Azure Monkshood). Violet-purple; $1 \mathrm{r} / 2$ to $2 \mathrm{ft}$.; September \& October. $\$ .40$ each, $\$ 3.50$ per 10 .

f. wilsoni (Violet Monkshood). Light violet; $6 \mathrm{ft}$.; Autumn. $\$ .75$ each, $\$ 6.00$ per 10 .

napellus (Aconite). Dark blue ; 3 to $4 \mathrm{ft}$. July and August.

$\$ .35$ each, $\$ 2.70$ per 10 .

u n c i n a t u m (Clambering Monkshood). Dark purple; 3 to $5 \mathrm{ft}$.; June to September.

$\$ .35$ each, $\$ 2.50$ per 10 .

BUGLE (Ajuga).

genevensis (Geneva Bugle). (R). Bright blue; 6 to 8 in.; May.

ONION (Allium).

thibetica. (R). Light blue; 6 to 8 in.; June and July.

HOLLYHOCK (Althaea rosea).

Double varieties-Red, Deep Rose, Newport Pink. White and Yellow; $5 \mathrm{ft}$; blooms all Summer.

$\$ .25$ each, $\$ 2.20$ per 10 .

Single varieties-Pink, White, Yellow, and Salmon; $5 \mathrm{ft}$.; blooms all Summer. $\$ .25$ each, $\$ 2.20$ per 10 .

ALYSSUM (Alyssum).

argenteum (Silver Alyssum). (R). Yellow ; 12 to 15 in. : June to August.

$\$ .25$ each, $\$ 2.20$ per 10 .

saxatile compactum (Dwarf Goldentuft). (R). Yellow ; $1 \mathrm{ft}$. ; mid-April to June. $\$ .25$ each. $\$ 220$ per 10 .

BUGLOSS (Anchusa).

italica Dropmore (Dropmore Bugloss). Blue ; 4 to $5 \mathrm{ft}$.; June.

\section{ANEMONE (Anemone).}

japonica (Japanese Anemone). Rosy red, $2 \mathrm{ft}$; Fall.

j. alba (White Japanese Anemone). White; 2 to $3 \mathrm{ft}$, August \& September.

j. rubra (Red Japanese Anemone). Rose ; 2 to $3 \mathrm{ft}$. : August and September.

sylvestris (Snowdrop A n e mone). (R). Cream white; 12 to 15 in. ; Apr. to July.

COLUMBINE (Aquilegia).

caerulea (Colorado Columbine). (R). Blue and White; 1 to $1 \mathrm{r} / 2 \mathrm{ft}$.; May to July.

canadensis (American Columbine). (R). Scarlet and Yellow; 2 ft.; May \& June. $\$ .25$ each, $\$ 2.20$ per 10 .

chrysantha (Golden Columbine). Yellow ; $3 \mathrm{ft}$. ; June to August.

flabellata nana (Fan Columbine). (R). Purple; 8 to 12 in.; June. $\$ .25$ each, $\$ 2.20$ per 10 .

long-spurred hybrids. (R). Red, Blue and Yellow; 2 to $3 \mathrm{ft}$.; May to August.

vulgaris (European Columbine). All shades of Blue, Red, White and Purple; 2 ft.; May to July. $\$$ '25 each, $\$ 2.20$ per 10 .

\section{ROCKCRESS (Arabis).}

albida fl. pl. (Double-flowered Wallcress)

(R). White ; 6 to 9 in.; May. $\$ .35$ each, $\$ 3.00$ per 10 .

alpina (Alpine Rockcress). (R). White; 9 in.; April and May.

$\$ .25$ each, $\$ 2.20$ per 10 .

alpina nana compacta (Dwarf A 1 p i n e Rockcress). (R). White; 6 in.; April and May.

\section{SANDWORT (Arenaria).}

verna caespitosa (Moss Sandwort). (R). White; 1 to 3 in. June. $\$ .35$ each, $\$ 2.70$ per 10 .

\section{THRIFT (Ameria).}

formosa alba. (R). White; 8 in.; May and June.

$\$ .25$ each, $\$ 2.20$ per 10

f. rosea. (R). Rose; 8 in. : May to June. $\$ .25$ each, $\$ 2.20$ per 10 . 
laucheana robusta. (R). Rose ; 8 to 10 in.; June to October.

maritima. (R). Purplish rose; 3 to 6 in.; May and June.

$\$ .25$ each, $\$ 2.20$ per 10 .

WORM WOOD (Artemisia).

abrotanum (Southernwood). Inconspicuous flowers; 3 to $4 \mathrm{ft}$.; August and September.

$\$ .50$ each, $\$ 4.50$ per 10 .

lactiflora (White Mugwort). White; 3 to to $4 \mathrm{ft}$.; August and September.

$\$ .35$ each, $\$ 2.70$ per 10 .

MILKWEED (Asclepias).

tuberosa (Butterflyweed). Orange; 18 to 24 in.; July to September.

$\$ .35$ each, $\$ 2.70$ per 10 .

ASTER (Aster).

alpinus (Rock Aster). (R). Blue ; 9 in. ; May and June.

$\$ .25$ each, \$2 20 per 10 .

novae-angliae (New England Aster). Violet-purple; 3 to $5 \mathrm{ft}$.; August and September.

$\$ .25$ each, $\$ 2.20$ per 10 .

\section{NAMED HARDY ASTERS}

Climax. Light lavender-blue ; 5 ft.; August to October.

Pink Perfection. Pink; 3 to $4 \mathrm{ft}$. ; August to October.

ASTILBE (Astilbe).

Betsy Cupereus. Pure white. pink center; $5 \mathrm{ft}$; July and August. $\$ .60$ each, $\$ 5.00$ per 10 .

Gloria. Deep Pink; 2 ft.; July and Aug. $\$ .40$ each, $\$ 3.50$ per 10 .

Marguerite Van Rechteren. Red, tinted lilac; $5 \mathrm{ft}$. : August. $\$ .60$ each, $\$ 5.00$ per 10 .

Moerheim. Pure White; $4 \mathrm{ft}$; July and August.

$\$ .50$ each, $\$ 4.00$ per 10 .

Rose Pearl. Shell Pink; 21/2 ft.; July and August.

$\$ .40$ each, $\$ 3.50$ per 10 .

Salland. Red; 6 ft.: July and August. $\$ .50$ each, $\$ 4.00$ per 10 .

astilboides (Goatsbeard Astilbe) White; 2 to $3 \mathrm{ft}$.

$\$ .35$ each, $\$ 2.70$ per 10 .

chinensis (Chinese Astilbe). Pink; 18 in.; July and August.

$\$ .35$ each, $\$ 2.70$ per 10 .

davidi (David Astilbe). Pink; 5 ft.; July and August.

$\$ .50$ each, $\$ 4.00$ per 10 .

japonica (Japanese Astilbe). White; $1 \mathrm{ft}$. June and July. $\$ .35$ each, $\$ 2.70$ per 10 . japonica varieties:

Peach Blossom. Soft pink; 15 to 18 in.; July and August. $\$ .40$ each, $\$ 3.50$ per 10 .

Queen Alexandra. Creamy pink; 2 ft.; June. $\$ .40$ each, $\$ 3.50$ per 10 .

W. E. Gladstone. Pure white; 2 ft.; June and July. $\$ .50$ each, $\$ 4.00$ per 10 .

AUBRIETIA (Aubrietia).

deltoides (Common Aubrietia). (R). Purple ; 3 to 4 in.; April and May.

$\$ .35$ each, $\$ 2.70$ per 10 .

WILD-INDIGO (Baptisia).

australis (Blue Wild-indigo). Deep Blue; 2 to $3 \mathrm{ft}$ : May and June.

tinctoria (Yellow Wild-indigo). Yellow; 2 to $3 \mathrm{ft}$.; July. $\$ .25$ each, $\$ 2.20$ per 10 .

ENGLISH DAISY (Bellis).

perennis (English Daisy). Red, White and Pink; 3 to 6 in.; April to June. $\$ .25$ each, $\$ 2.20$ per 10 .

BOLTONIA (Boltonia).

asteroides (White Boltonia). White; 5 to $6 \mathrm{ft}$. September and October. $\$ .25$ each, $\$ 2.20$ per 10.

latisquama (Violet Boltonia). Violet; 4 ft.; July to October.

$\$ .25$ each, \$2.20 per 10 .

POPPY-MALLOW (Callirhoe).

involucrata (Low Poppy-Mallow). (R). Cherry red; 9 to 12 in.; all Summer.

BELLFLOWER (Campanula).

alliariaefolia (Spurred Bellflower). (R). White: $1 \mathrm{~T} / 2$ to $2 \mathrm{ft}$; July.

$\$ .40$ each. $\$ 3.50$ per 10 .

carpatica (Carpathian Bellflower). (R). Dark blue; 9 in. ; June to October.

garganica (Gargano Harebell). (R). Blue, 3 to 4 in.; June to September.

$\$ .35$ each, $\$ 2.70$ per 10 .

medium (Canterbury-Bell). Pink, blue, white and mixed; 2 to $3 \mathrm{ft}$.; June and July.

m. calycanthema (Cup-and-Saucer Bellflower). Pink, blue, white and mixed; 2 to $3 \mathrm{ft}$; ; July.

persicifolia (Peachleaf Bellflower). Blue, 2 to $3 \mathrm{ft}$; : June to July.

rotundifolia (Harebell). (R). Blue; $1 \mathrm{ft}$; June to August.

SEDGE (Carex).

morrowi variegata (Silveredge Morrow Sedge). (R). Grass-like plant; $1 \mathrm{ft}$. $\$ .35$ each. $\$ 3.00$ per 10 .

CENTAUREA (Centaurea).

montana (Mountain-bluet). (R). Bluishviolet; 20 in.; July to August. 
CERASTIUM (Cerastium).

tomentosum (Snow - in - Summer). (R).

White; 3 to 6 in.; May and June. $\$ .25$ each, \$2.20 per 10 .

PLUMBAGO (Ceratostigma). plumbaginoides (Larpente plumbago). (R). Blue; 6 to 8 in.; May to Sept. $\$ .35$ each, $\$ 2.70$ per 10 .

WALLFLOWER (Cheiranthus).

allioni (Wallflower). (R). Orange-yellow, 6 to 12 in.; May to July.

CHRYSANTHEMUM (Chrysanthemum).

(Also see Pyrethrum).

coreanum (Korean Chrysanthemum). (R). Rose-pink; 2 to $3 \mathrm{ft}$; Sept. and Oct.

$\$ .35$ each, $\$ 2.70$ per 10 .

maximum (Shasta Daisy). White; 21/2

ft.; July to October.

$\$ .25$ each, \$2.20 per 10 .

\section{NAMED}

\section{HARDY CHRYSANTHEMUMS}

A. Barham. Golden Bronze.

Autumn Glow. Large rose-crimson.

Boston. Golden bronze.

Cranford White. White.

Cranfordia. Golden bronze.

Eden. Pink.

Field of Snow. Large white.

Glory of Seven Oaks. Golden Yellow.

Golden Pheasant. Orange yellow.

Gypsy Girl. Bright crimson.

$\$ .50$ each, $\$ 4.00$ per 10 .

Indian. Bright Indian red.

Lillian Doty. Soft pink.

Little Bob. Bronze Button.

Lucifer. Early ox-blood red pompom.

Marie Antoinette. Large deep pink.

Old Homestead. Large pink.

Rose Gem. Rose pink.

$\$ .50$ each, $\$ 4.00$ per 10 .

Ruth Hatton. Clear ivory-white pompom. $\$ .50$ each, $\$ 4.00$ per 10 .

Skibo. Yellow button.

BUGBANE (Cimicifuga).

racemosa (Cohosh Bugbane). White; 4

to $6 \mathrm{ft}$; July to September.

CLEMATIS (Clematis). (See Vines also.) heracleaefolia davidiana (Fragrant Tube Clematis). Pale blue; 3 ft.. August and September.

integrifolia. Blue flowers; $2 \mathrm{ft}$; June to August.

$\$ .40$ each, $\$ 3.50$ per 10 .

recta (Ground Clematis). White; 2 to $3 \mathrm{ft}$. $\$ .35$ each, $\$ 3.00$ per 10 .

LILY-OF-THE-VALLEY (Convallaria).

majalis. White; 8 in.; May.

Clumps, $\$ .50$ each, $\$ 4.50$ per 10 .

Strong Pips. \$ .15 each, \$1.00 per 10.
COREOPSIS (Coreopsis).

grandiflora (Big Coreopsis). Yellow; 2 to $3 \mathrm{ft}$; May to November.

$\$ .25$ each, \$2.20 per 10 .

lanceolata (Lance Coreopsis). Yellow; 2 ft.; June to September.

$\$ .25$ each, \$2.20 per 10 .

LARKSPUR (Delphinium).

Belladonna. Pale blue; 3 to $4 \mathrm{ft}$; June and July.

Bellamosum. Dark blue form of Belladonna; 3 to $4 \mathrm{ft}$; June and July.

Blackmore \& Langdon Hybrids. Blue, lavender, violet and mauve; 4 to $5 \mathrm{ft}$.; June and July. $\$ .50$ each, $\$ 4.00$ per 10 .

Hybrids. Mixed colors; 2 to $2 \mathrm{~L} / 2 \mathrm{ft}$; June and July.

grandiflora chinense (Slender Larkspur). All shades of blue; 2 to $3 \mathrm{ft}$.; June to August.

PINK (Dianthus).

alpinus. (R). Rose-pink; 3 in. ; June and July.

$\$ .50$ each, $\$ 4.00$ per 10

Allwoodi (Allwood's Pinks). White, pink and crimson; 12 to $15 \mathrm{in.}$; May to Oct.

var. Beatrix. Salmon pink; 9 to 12 in.; May and July.

$\$ .35$ each, $\$ 3.00$ per 10 .

barbatus (Sweet William). Pink, red and white; 10 to 20 in.; June and July.

$\$ .25$ each, \$2.20 per 10 .

caesius (Cheddar Pink). (R). Pink; 3 to 6 in.; May to July.

deltoides (Maiden Pink). (R). Dark red; 6 in.; June and July.

d. alba (White Mí a ide n Pink). (R). White: 6 in.; June and July.

plumarius (Grass Pink). Pink, white and purplish; 9 to 12 in.; June.

$\$ .25$ each, $\$ 2.00$ per 10 .

\section{NAMED HARDY PINKS}

Bristol Jewel.

$\$ .50$ each, $\$ 4.00$ per 10 .

Bristol Maid.

$\$ .50$ each, $\$ 4.00$ per 10 .

Bristol Purity.

$\$ .50$ each, $\$ 4.00$ per 10 .

Her Majesty. (R). Large pure white.

Lord Lyons. (R). Pink.

Rose de May. (R). Delicate pink; 9 to 15 in.; all Summer.

$\$ .35$ each, $\$ 3.00$ per 10 .

GASPLANT (Dictamnus).

albus (White Gasplant). White; 2 to 3

ft.: June and July.

$\$ .40$ each, $\$ 3.50$ per 10 .

a. caucasicus (Giant Gasplant). White; 3 to $4 \mathrm{ft}$.; June and July.

$\$ .45$ each, $\$ 4.00$ per 10 . 


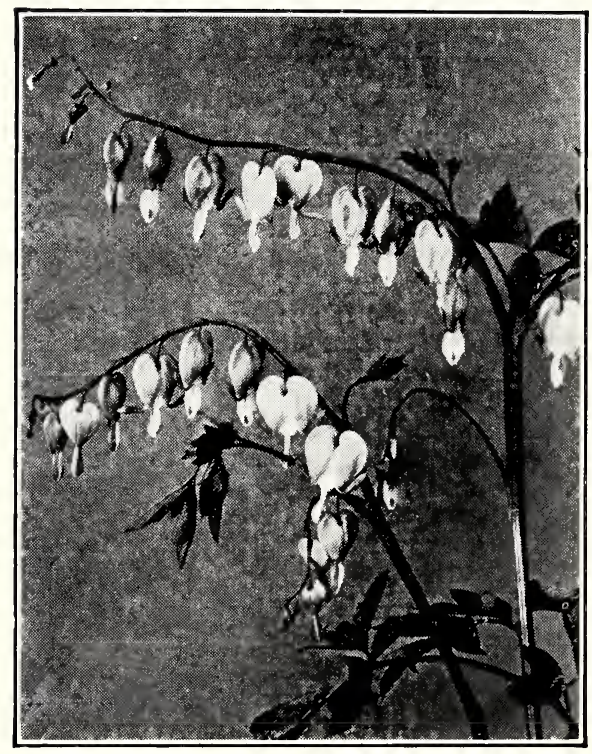

Bleedingheart.

BLEEDINGHEART (Dicentra).

eximea (Fringed Bleedingheart). (R). Rose: 12 in.; all Summer. $\$ .35$ each, $\$ 2.70$ per 10 .

formosa (Western Bleedingheart).

Pink; 15 in.; April to August.

$\$ .35$ each, $\$ 2.70$ per 10 .

spectabilis (Bleedingheart). Rosy red;

24 in.; April to July.

$\$ .60$ each, $\$ 5.00$ per 10 .

FOXGLOVE (Digitalis).

ambigua (Yellow Foxglove). Yellow; 2 to $3 \mathrm{ft}$; J June to July.

purpurea (Common Foxglove). Purple; 2 to $3 \mathrm{ft}$.; July to September.

p. alba (Common White Foxglove). White; 2 to $3 \mathrm{ft}$. July to September.

LEOPARDBANE (Doronicum).

clusi (Downy Leopardbane). Yellow; 2

$\mathrm{ft}$; J June and Julv.

$\$ .50$ each, $\$ 4.00$ per 10 .

WHITLOWGRASS (Draba).

fladnizensis (Arctic Whitlowgrass). (R). Yellow; 3 in.; April.

$\$ .50$ each, $\$ 4.50$ per 10 .

HEDGEHOG - CONEFLOWER (E c hi nacea).

purpurea (Purple Coneflower). Purple;

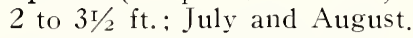

GLOBETHISTLE (Echinops).

pumilum (Globethistle). Blue ; 3 ft.; Aug. $\$ .25$ each, $\$ 2.20$ per 10 .
FLEABANE (Erigeron).

caucasicus. (R). Violet, yellow center; 12 in.; June and July. $\$ .50$ each, $\$ 4.00$ per 10 .

BLISTERCRESS (Erysimium).

pulchellum (Rockery Blistercress). (R). Orange-yellow; 6 to $12 \mathrm{in.}$

EUPATORIUM (Eupatorium).

urticaefolium (ageratoides) (Snow Thoroughwort). White; 2 to $3 \mathrm{ft}$.; August to September.

$\$ .35$ each, $\$ 2.70$ per 10 .

SPURGE (Euphorbia).

corollata (Flowering Spurge). White; 18 in.: July and August.

$\$ .25$ each, \$2.20 per 10 .

\section{HARDY FERNS}

Adiantum pedatum (American Maidenhair Fern). (R). Fan-like foliage; 12 to 15 in.

Polystichum acrostichoides ( $\mathrm{C}$ h r is t mas Fern). (R). Evergreen; $1 \mathrm{ft}$.

FESCUE (Festuca).

glauca (Blue Fescue). (R). Blue foliage; 10 to $12 \mathrm{in}$.

MEADOWSWEET (Filipendula).

camtschatica (Spirea gigantea) (Kamchatka Meadowsweet). White; 5 to 6 ft.; July.

hexapetala (Spirea filipendula) (Dropwort). (R). White; 2 to $3 \mathrm{ft}$.; June and July.

hex. fl. pl. (D o uble Dropwort). (R). Double white; 12 to 15 in.; June and July.

PLANTAINLILY (Funkia). See Hosta.

GAILLARDIA (Gaillardia).

aristata grandiflora. Dark crimson and gold; 2 ft.; July to frost.

$\$ .25$ each, $\$ 2.20$ per 10 .

a. maxima. Crimson and yellow; $2 \mathrm{ft}$; July to frost.

$\$ .25$ each, $\$ 2.20$ per 10 .

BEDSTRAW (Galium).

verum (Yellow Bedstraw). (R). Yellow. $\$ .50$ each, $\$ 4.00$ per 10 .

CRANESBILL (Geranium).

sanguineum (Bloodred Cranesbill). (R). Blood-red; 18 in.; May to October.

AVENS (Geum).

chiloense atrosanguineum (Double Crimson Geum). Dark red; 1 to $1 \frac{1 / 2}{\mathrm{ft}}$. ; May to July.

c. Mrs. Bradshaw. Scarlet; 12 to 15 in.; June to September. $\$$.35 each, $\$ 3.00$ per 10 .

Lady Strathedon. (R). Golden yellow; 18 in.; June to September. $\$ .35$ each, $\$ 3.00$ per 10 . 


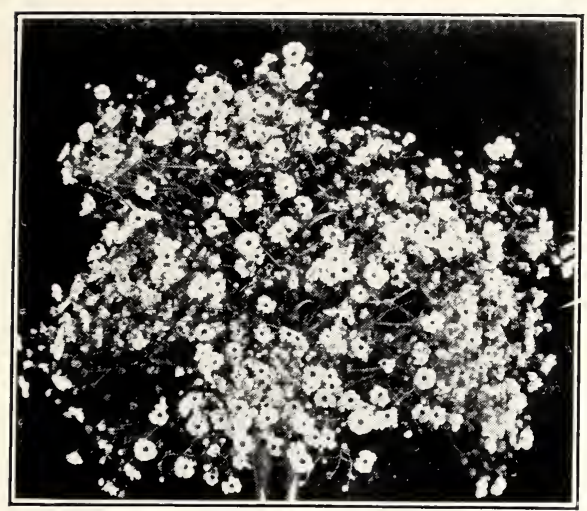

Gypsophila Bristol Fairy.

\section{GYPSOPHILA (Gypsophila).}

paniculata (Babysbreath). White; 2 to $3 \mathrm{ft}$.; July and August.

paniculata fl. pl. (Double Babysbreath). Double white; $3 \mathrm{ft}$.; July and August. $\$ .40$ each, $\$ 3.50$ per 10 .

paniculata fl. pl. Bristol Fairy. Double white; 2 to $3 \mathrm{ft}$.; June to October.

3 years.......\$ $\$ .75$ each, $\$ 6.00$ per 10

2 years _....... \$.60 each, $\$ 5.00$ per 10

repens (Creeping Gypsophila). (R).

White; 6 in.; June and July.

SNEEZEWEED (Helenium).

autumnale (Common Sneezeweed). Golden yellow ; 4 to $6 \mathrm{ft}$; ; August and Sept.

a. Riverton Beauty. Yellow; 4 to $5 \mathrm{ft}$; August to October.

$\$ .35$ each, $\$ 2.70$ per 10 .

a. Riverton Gem. Red; 4 to $5 \mathrm{ft}$; August to November.

$\$ .35$ each, $\$ 2.70$ per 10 .

hoopesi (Orange Sneezeweed). Orange; $1 \mathrm{r} / 2$ to $2 \mathrm{ft}$.; May to August.

$\$ .35$ each, $\$ 2.70$ per 10 .

SUNROSE (Helianthemum).

halimifolium multiflorum (Morocco Sunrose). (R). Orange pink; 4 to 6 in.; June to September.

SUNFLOWER (Helianthus).

decapetalus (Thinleaf Sunflower). Yellow; 4 to $5 \mathrm{ft}$.; August to October.

$\$ 25$ each, \$2 20 per 10 .

mollis (Ashy Sunflower). Lemon yellow ;

3 to $4 \mathrm{ft}$.; July to September.

$\$ .25$ each, \$2.20 per 10.

DAYLILY (Hemerocallis).

flava (Lemon Daylily). Bright yellow;

$3 \mathrm{ft}$.; May and June.

$\$ .40$ each, $\$ 3.00$ per 10 . fulva (Tawny Daylily). Dusty orange; 2 to $3 \mathrm{ft}$.; June and July.

$\$ .25$ each, $\$ 2.20$ per 10 .

middendorfi (Amur Daylily). Gold e n orange; 2 to $3 \mathrm{ft}$.; June and July.

thunbergi (Japanese Daylily). Buttercup yellow; $3 \mathrm{ft}$; July.

\section{BETSCHER'S \\ HYBRID HEMEROCALLIS}

Bay State. Deep yellow; 21/2 ft.; July and August.

$\$ 2.00$ each, $\$ 18.00$ per 10 .

Mrs. W. H. Wyman. Pale lemon-yellow;

$2 \mathrm{r} / 2 \mathrm{ft}$.; July and August. $\$ 2.00$ each, $\$ 18.00$ per 10.

BURSTWORT (Herniaria).

glabra (Burstwort). (R). Greenish, inconspicuous flowers; 2 in.; July and August.

$\$ .40$ each, $\$ 3.50$ per 10 .

ROCKET (Hesperis).

matronalis (Dame's Rocket). (R). Purple; 2 to $3 \mathrm{ft}$.; June and July.

ALUMROOT (Heuchera).

sanguinea (Coralbells). (R). Coral; 12 to 18 in.; June to September.

$\$ .35$ each, $\$ 2.70$ per 10 .

s. alba (White Coralbells). (R). White; 12 to 18 in.; June to September.

$\$ .35$ each, $\$ 2.70$ per 10 .

Grenadin Scarlet. (R). Scarlet.

$\$ .35$ each, $\$ 2.70$ per 10 .

Perry's White. (R). White; 1 to $2 \mathrm{ft}$; May to September.

$\$ .35$ each, $\$ 2.70$ per 10 .

Shirley Hybrids. (R). Deep rose; $2 \mathrm{ft}$; June to September.

ROSEMALLOW (Hibiscus).

moscheutos (Com mon Rosemallow). Rose-red; 3 to $4 \mathrm{ft}$; August and Sept.

PLANTAINLILY (Hosta).

caerulea (Blue Plantainlily). Blue; 1 to $2 \mathrm{ft}$.; July and August.

lancifolia undulata variegata (Wavyleaf Plantainlily). Blue; $1 \mathrm{ft}$; June \& July.

ST. JOHNSWORT (Hypericum).

repens. (R). Yellow; 4 to 6 in. ; August. $\$ .40$ each, $\$ 3.50$ per 10 .

HYSSOP (Hyssopus).

officinalis (Hyssop). (R). Purple; 1 to $2 \mathrm{ft}$ : June to August.

officinalis rosea. (R). Pink; 1 to $2 \mathrm{ft}$; June to August.

CANDYTUFT (Iberis).

gibraltarica (Gibraltar Candytuft). (R).

White: 8 in.; May and June.

sempervirens (Evergreen Candytuft). (R).

White; $1 \mathrm{ft}$. May.

s. Little Gem. (R). White : 6 in.; May.

We emphasize quality, service and satisfaction. 


\section{IRIS}

EARLY FLOWERING (Alpine). (R).

Lobelia. Blue ; 6 to 9 in.; March to May. $\$ .50$ each.

Orange Queen. Orange; 9 in.; March to May.

$\$ .50$ each.

The following abbreviations are used: " $S$ " for Standards, or upper petals; "F" for Falls, or lower petals.

TALL BEARDED (German). Flower in June: $2 \frac{1}{2}$ to $3 \mathrm{ft}$.

Florentina Blue. Blue.

Her Majesty. S. rose-pink, F. crimson. $\$ .35$ each, $\$ 3.00$ per 10 .

Kochi. Dark purple.

Lorely. S. light yellow, F. deep blue. $\$ .35$ each, $\$ 2.70$ per 10 .

Madame Chereau. White, feathered in blue.

Pauline. S. bright blue, F, dark blue.

Perfection. S. light blue, F purplishblack. $\$ .35$ each, $\$ 3.00$ per 10 .

Princess Victoria Louise. S. sulphur yellow, F. rich plum. $\$ .35$ each, $\$ 2.70$ per 10 .

Rebecca. S. golden yellow, F. yellow veined in brown.

Rhein Nixe. S. pure white. F. violet-blue. $\$ .35$ each, $\$ 3.00$ per 10 .

Mixed. $\$ .25$ each, \$2.00 per 10 .

JAPANESE (Kaemfferi). Flowers in middle July ; $3 \mathrm{ft}$.

Alida. White, striped in light blue. $\$ .50$ each, $\$ 4.00$ per 10 .

Helen von Siebold. Deep pink, white lines. $\$ .50$ each, $\$ 4.00$ per 10 .

Mahogany. Dark red, shaded maroon. $\$ .50$ each, $\$ 4.00$ per 10 .

Neptune. Violet overlaid with dark blue. $\$ .50$ each, $\$ 4.00$ per 10 .

Paragon. Purple. $\$ .50$ each, $\$ 4.00$ per 10 .

Purple and Gold. $\$ .50$ each, $\$ 4.00$ per 10 .

\section{MISCELLANEOUS IRIS}

pumila cyanea. (R). Deep blue, dwarf; April.

$\$ .35$ each, $\$ 2.70$ per 10 .

sibirica. Pale blue; $3 \mathrm{ft}$; June.

SHEEP'S-BIT (Jasione).

perennis (Sheep's-bit). (R). Blue; 6 to 12 in.; July and August.

TORCHLILY (Kniphofia). uvaria grandiflora (Dayglow Torchlily). Red; 3 to $4 \mathrm{ft}$. ; August to October. u. pfitzeriana (Bonfire Torchlily). Orangescarlet; 2 to $3 \mathrm{ft}$; August to October. tucki (Tuck Torchlily). Orange scarlet; 2 to $3 \mathrm{ft}$. : August to October.

PEA (Lathyrus).

latifolius (Perennial Pea). Rosy red ; $4 \mathrm{ft}$; July to September.

LAVENDER (Lavandula).

officinalis (vera) (True Lavender). Blue; $1 \mathrm{I} / 2$ ft.; July and August.

$\$ .35$ each, $\$ 2.70$ per 10 .

GAYFEATHER (Liatris).

pycnostachya (Cattail Gayfeather). Pale purple ; 3 to $5 \mathrm{ft}$; August to October. spicata (Spike Gayfeather). Rosy purple; 2 to $3 \mathrm{ft}$.; July to September.

GROUNDSEL (Ligularia).

clivorum (Senecio clivorum) (Ragweed). Yellow; $4 \mathrm{ft}$; June to August. $\$ .40$ each, $\$ 3.50$ per 10 .

LILY (Lilium).

auratum (Goldband Lily). White; 3 ft.; July and August.

$\$ .50$ each, $\$ 4.00$ per 10 .

candidum (Madonna Lily). White; 2 to $3 \mathrm{ft}$.; June and July.

$\$ .40$ each, $\$ 3.50$ per 10 .

elegans. Orange to deep maroon; $1 \mathrm{t} / 2 \mathrm{ft}$.; June and July.

$\$ .35$ each, $\$ 3.00$ per 10 .

hansoni (Hanson Lily). Apricot-yellow dotted with brown; 3 to $4 \mathrm{ft}$.; June.

$\$ .75$ each, $\$ 6.00$ per 10 .

henryi (Henry Lily). Apricot-orange; 6 to $8 \mathrm{ft}$; July and August.

$\$ .75$ each, $\$ 6.00$ per 10 .

longiflorum giganteum ( $\mathrm{G}$ i an t Lily). White: 4 to $5 \mathrm{ft}$. July and August.

$\$ .60$ each, $\$ 5.00$ per 10 .

regale (Royal Lily). White, shaded pink; 2 to $3 \mathrm{ft}$.; August.

$\$ .60$ each, $\$ 5.50$ per 10 .

speciosum album (White $\mathrm{S} p$ e c ios $\mathrm{um}$ Lily). White; $3 \mathrm{ft}$; August and Sept. $\$ .50$ each, $\$ 4.40$ per 10 .

s. rubrum (Red Speciosum Lily). Red; $3 \mathrm{ft}$; August and September. $\$ .40$ each, $\$ 3.50$ per 10 .

tigrinum (Tiger Lily). Orange-red, spotted purple; 2 to $5 \mathrm{ft}$; August.

FLAX (Linum).

flavum (Golden Flax). (R). Yellow ; $1 \mathrm{ft}$; June and July $\$ .35$ each, $\$ 2.70$ per 10 .

LOBELIA (Lobelia).

cardinalis (Cardinalflower). S c a r l e t; $3 \mathrm{ft}$; July and August.

LUPINE (Lupinus).

polyphyllus (Washington Lupine). Deep blue: 2 to $3 \mathrm{ft}$.; June to September.

p. albiflorus (White Washington Lupine). White: $3 \mathrm{ft}$.; June to September. 
p. Moerheimi (Moerheim Lupine). Pink; 2 to $3 \mathrm{ft}$; J June to September. $\$ .35$ each, $\$ 2.70$ per 10 .

p. roseum (Blush Lupine). Rosy-pink; $3 \mathrm{ft}$; June to September. $\$ .35$ each, $\$ 2.70$ per 10 .

Yellow Cloud. Yellow; 2 to $3 \mathrm{ft}$; June to September.

$\$ .35$ each, $\$ 3.00$ per 10 .

Sutton's Hybrids. Yellow; 2 to $3 \mathrm{ft}$; June to September.

$\$ .35$ each, $\$ 3.00$ per 10 .

CAMPION (Lychnis).

alpina (Arctic Campion). (R). Reddish purple; 4 in.; August.

$\$ .35$ each, $\$ 2.70$ per 10 .

chalcedonica (Maltese Cross). Orangescarlet; 2 to $3 \mathrm{ft}$.; June to August.

coronaria (Rose Campion). Carmine; 18 in. ; June and July.

$\$ .25$ each, $\$ 2.20$ per 10 .

viscaria splendens (Rosepink Campion). Rose-pink; 12 to 15 in.; June and July. viscaria splendens fl. pl. (Double Rosepink Campion). Rose-pink: 12 to 15 in.; June and July.

LOOSESTRIFE (Lysimachia).

nummularia (Moneywort). (R). Yellow: 4 in.; June and July.

$\$ .25$ each, $\$ 2.20$ per 10 .

LYTHRUM (Lythrum).

s a. li c a r i a roseum (Rose Loosestrife). Rose: 4 to $5 \mathrm{ft}$.; July to September.

MALLOW (Malva).

alcea (Hollyhock Mallow). Pink; 2 ft.; all Summer.

MINT (Mentha).

reauieni (Requien Mint). ( $R)$. Mauve: 2 to 4 in.; Julv and August.

$\$ .35$ each, $\$ 3.00$ per 10 .

spicata (Spearmint). Purple: 18 in. ; July and August.

BLUEBELLS (Mertensia).

virginica (Virginia Bluelells). (R). Blue; 1 to $2 \mathrm{ft}$; April to June.

BEEBALM (Monarda)

didyma (Oswego Beehalm). Scarlet : 11/2 to $2 \mathrm{~T} / 2 \mathrm{ft}$.; June to September.

FORGET-ME-NOT (Myosotis).

dissitiflora (Swiss Forget-me-not). (R). Skv-blue: 6 to 10 in.; May to July.

$\$ .25$ each, $\$ 2.20$ per 10 .

scorpioides semperflorens (Dwarf Perpetual Forget-me-not). (R). Light

blue: 8 in. ; June to September.

$\$ .25$ each, $\$ 2.20$ per 10 .

CUPFLOWER (Nierembergia).

rivularis (Whitecup). (R). White; 6 in. ; June to August.

$\$ .35$ each, $\$ 2.70$ per 10 .
EVENING-PRIMROSE or SUNDROPS (Oenothera).

glauca fraseri (Fraser Sundrops). Yellow ; $1 \mathrm{ft}$; June to August.

missouriensis ( $\mathrm{Oz}$ a rk Sundrops). (R).

Bright yellow ; 10 in.; June to August. $\$ .40$ each, $\$ 300$ per 10 .

speciosa. Pure white; 18 in. August and September.

$\$ .35$ each, $\$ 2.70$ per 10 .

JAPANESE PACHYSANDRA (Pachysandra).

terminalis. (R). Ground cover $-\mathrm{w}$ h i t e flowers; May and June.

$\begin{array}{lll}\text { Field grown } & \text { Per } 10 . & \text { Per } 100 . \\ 3 \text { inch Pots } & \$ 2.50 & \$ 18.00 \\ \end{array}$

PEONY (Paeonia). Flower in June and July ; about $2 \mathrm{ft}$. tall.

Edulis Superba. Early soft pink.

$\$ .75$ each, $\$ 6.00$ per 10 .

Felix Crousse. Medium bright red. $\$ 1.00$ each, $\$ 9.00$ per 10 .

Festiva Maxima. Early white, with crimson markings.

$\$ .75$ each, $\$ 6.50$ per $10, \$ 50$ per 100 .

Karl Rosenfield. Very large dark crimson. $\$ 1.50$ each, $\$ 14.00$ per 10 .

Officinalis Rubra. Large vivid crimson. $\$ .95$ each, $\$ 8.00$ per 10 .

Mixed. Mixed colors.

$\$ .50$ each, $\$ 4.50$ per 10 .

POPPY (Papaver).

nudicaule (Iceland Poppy). (R). Orange, white, yellow ; $1 \mathrm{ft}$; all Summer.

orientale (Oriental Poppy). Scarlet; 2 to $3 \mathrm{ft}$; May to July.

HYBRID ORIENTAL POPPIES. July; 3 to $4 \mathrm{ft}$. $\$ .50$ each, $\$ 4.00$ per 10 .

Beauty of Levermere. Blood-red.

Goliath. Scarlet.

Lorely. Orange-scarlet.

Mrs. Perry. Salmon pink.

Olympia. Scarlet.

Orange Queen. Orange.

Oriflame. Orange scarlet.

Perry White. White.

Princess Victoria Louise. Salmon pink.

PENTSTEMON (Pentstemon).

heterophyllus (Violet Pentstemon). Violet ; 2 ft.; June and Tuly.

laevigatus digitalis (Foxglove Pentstemon). White; $3 \mathrm{ft}$; June and July.

torreyi (Torrey Pentstemon). Scarlet; $2^{1} / 2$ to $3^{1} / 2 \mathrm{ft}$.; July.

ORNAMENTAL GRASS (Phalaris).

arundinacea variegata (Ribbon Grass). 2 to $3 \mathrm{ft}$.

PHLOX (Phlox). These grow $2 \mathrm{~T} / 2$ to $3 \mathrm{ft}$., flowering from July on. 
Garden Phlox (paniculata).

Annie Cook. Flesh pink.

Atlas. Salmon pink.

B. Comte. Dark red.

Baur's Pink. Bright pink.

Blue Hill. Nearest to a blue Phlox of any variety we have seen.

$\$ .35$ each, $\$ 3.00$ per 10 .

Boule de Feu. Cherry red.

Commander - in - Chief. Crimson with dark eye.

$\$ .35$ each, $\$ 3.00$ per 10 .

Debs. Bright fiery crimson.

$\$ .75$ each, $\$ 7.00$ per 10 .

Deutschland. Rich scarlet. $\$ .35$ each, $\$ 2.70$ per 10 .

Elizabeth Campbell. Bright salmonpink, dark red eye.

$\$ .35$ each, $\$ 3.00$ per 10 .

Enchantress. Bright salmon-pink. $\$ .35$ each, $\$ 3.00$ per 10 .

Eugene Damsel. Pink.

Independence. Pure white.

Jules Sandeau. Pure pink, large.

$\$ .35$ each, $\$ 3.00$ per 10 .

Lord Raleigh. Purple.

Maid Marion. Soft lavender.

$\$ .35$ each, $\$ 3.00$ per 10 .

Mme. P. Langier. Bright red with vermilion center.

Mrs. Jenkins. Pure white.

Pantheon. Brilliant rose.

Percheau d'Island. Tall with deep red blossoms.

R. B. Struthers. Bright pinkish salmon, crimson eye.

Rijnstroom. Bright carmine rose,

Special French. Glowing pink.

Tapis Blanc. Dwarf white.

$\$ .35$ each, $\$ 2.70$ per 10 .

Thor. Deep salmon pink.

Victor. Bright salmon pink.

divaricata. ( $\mathrm{R}$ ). (Blue Phlox). Lilac-

blue; $1 \mathrm{ft}$; May and June. $\$ 40$ each, $\$ 3.00$ per 10 .

suffruticosa (Indian Chief). Purple-red; $1 \mathrm{I} / 2$ to $2 \mathrm{ft}$. ; June.

s. Miss Lingard. White; 2 to $3 \mathrm{ft}$. June and July.

subulata (Moss Pink). (R). Pink; 4 in.; May and June.

$\$ .25$ each, $\$ 2.20$ per 10 .

s. alba (White Moss Pink). (R). Same as above, only white.

$\$ .25$ each. $\$ 220$ per 10 .

s. G. F. Wilson (Blue Moss Pink). (R). Lilac-blue.

$\$ .25$ each, $\$ 2.20$ per 10 .

s. lilacina. (R). Lilac color. $\$ .25$ each, $\$ 2.20$ per 10 . s. The Bride. (R). White, pink eye.

s. Vivid. (R). Bright fiery rose. $\$ .50$ each, $\$ 4.00$ per 10 .

GROUNDCHERRY (Physalis).

francheti (Lantern Groundcherry). White; 1 to $2 \mathrm{ft}$.; July.

BALLOONFLOWER (Platycodon). grandiflora (Balloonflower). Deep blue; 18 in.; June to October.

PLUMBAGO. See Ceratostigma.

POLEMONIUM (Polemonium).

caeruleum (Greek-valerian). (R). Blue ; $1 \mathrm{I} / 2$ to $2 \mathrm{ft}$.; June to September.

c. album (White Greek-valerian). (R). White; $1 \mathrm{I} / 2$ to $2 \mathrm{ft}$. June to September. $\mathrm{reptans}$ (Creeping Polemonium). (R). Blue : 8 to 10 in.; April to June.

CINQUEFOIL (Potentilla).

atrosanguinea (Himalayan Cinquefoil). (R). Crimson: 18 in.; June to August.

hybrida Miss Willmott. (R). Cerise; 9 in. : June to August.

$\$ .35$ each, $\$ 2.70$ per 10 .

PRIMROSE (Primula)

acaulis (English Primrose). (R). Yellow: 6 to 8 in. : May and June.

$\$ .35$ each, $\$ 2.70$ per 10 .

beesiana. (R). Purple; 2 ft.; May and June.

$\$ .35$ each, $\$ 2.70$ per 10 .

elatior (Oxlip Primrose). White; 8 to 12 in.; May and June.

$\$ .35$ each, $\$ 2.70$ per 10 .

japonica (Japanese Primrose). L ig h t pink; 1 to $2 \mathrm{ft}$. May and July.

polyantha (Munstead Strain). (R). Yellow to orange; 6 to 12 in.; May and June.

veris (Cowslip Primrose). (R). Upright form; crimson to dark yellow; 6 in.; April and May.

SELFHEAL (Prunella).

grandiflora (Great Selfheal). (R). Blue; 9 to $10 \mathrm{in.}$ : June and July.

PERSIAN DAISY (Pyrethrum).

roseum single. White. light pink, dark pink and red; 2 ft.; May and June.

$\$ .35$ each, $\$ 3.00$ per 10 .

ros e u m single, mixed. Mixed colors; $2 \mathrm{ft}$. : May and June.

roseum atrosanguineum (Single $\mathrm{Cr}$ i m son). Crimson; $2 \mathrm{ft}$.; May and June.

BUTTERCUP (Ranunculus).

acris fl. pl. (Tall Double Buttercup). Yellow ; $2 \mathrm{ft}$; May to September.

repens (Creeping Buttercup). (R). Yellow ; 8 in.; May to July.

CONEFLOWER (Rudbeckia).

laciniata Goldenglow. Yellow ; 5 to $6 \mathrm{ft}$. ; July to September. $\$ .25$ each, $\$ 220$ per 10 .

triloba (Brown-eyed Susan). Deep yellow ; 3 to 5 ft.; July and August. 
SAGE (Salvia).

azurea grandiflora (Great Azure Sage). Light blue; 3 to $4 \mathrm{ft}$.; Aug. and Sept. officinalis (Garden Sage). Whitish; 1 to $2 \mathrm{ft}$; June and July.

BLOODROOT (Sanguinaria).

canadensis (Bloodroot). (R). White; 6 to 10 in.; April and May.

$\$ .25$ each, $\$ 2.20$ per 10 .

LAVENDER-COTTON (Santolina).

chamaecyparissus (Lavender - Cot t o n). (R). Yellow; 12 in.

SOAPWORT (Saponaria).

ocymoides (Rock Soapwort)。(R). Pink; 6 in.; May to August.

$\$ .35$ each, $\$ 2.70$ per 10 .

SAXIFRAGE (Saxifraga).

crassifolia (Le a the $\mathrm{r}$ Saxifrage). (R). Pink; 12 to 15 in.; April to June. $\$ .35$ each, $\$ 2.70$ per 10 .

McNabiana. White; $1 \mathrm{ft}$; May \& June. $\$ .40$ each, $\$ 3.50$ per 10 .

SCABIOSA (Scabiosa).

caucasica (Caucasian Scabiosa). Lilacblue; 18 to 24 in.; June to September. $\$$.35 each, $\$ 2.70$ per 10 .

japonica (Japanese Scabiosa). Blue ; 2 ft.; July to September.

Pennsylvanicum. Creamy white; $6 \mathrm{ft}$; July and August.

STONECROP (Sedum). (R).

acre (Goldmoss). (S). Yellow; 2 to $t$ in.; May and June.

$\$ .25$ each, $\$ 2.20$ per 10 .

a. minor. (S). Yellow: 2 to 3 in.: June. album (White Stonecrop). (S). White; 4 to 6 in.; July and August. $\$ .25$ each, $\$ 2.20$ per 10 .

a. brevifolium. (S).

$\$ .35$ each, $\$ 3.00$ per 10 .

a. murale. (S).

$\$ .35$ each, $\$ 3.00$ per 10 .

altissimum (Tall Stonecrop). (S). White; 6 to $12 \mathrm{in.:}$ July and August.

$\$ .35$ each, $\$ 3.00$ per 10 .

a. nicaense. (S).

$\$ .35$ each, $\$ 3.00$ per 10 .

aizoon

$\$ .35$ each, $\$ 3.00$ per 10

anopetalum. (S). White: 8 to $10 \mathrm{in.}$; July and August.

$\$ .35$ each, $\$ 3.00$ per 10 .

dasyphyllum (Leafy Stonecrop). Pinkish white; 3 in.

$\$ .35$ each, $\$ 3.00$ per 10 .

Edinboro (Trade name).

$\$ .35$ each, $\$ 3.00$ per 10 .

ewersi (Ewers Stonecrop). Purplish pink;

4 to 6 in.; September and October.

hispanicum (Spanish Stonecrop). $3 \mathrm{in.}$ kamtschaticum (Orange Stonecrop).

Orange-yellow; 6 to 9 in.; July \& Aug. $\$ .25$ each, \$2.20 per 10 .

lydium (Lydian Stonecrop). White; 2 in. $\$ .25$ each, $\$ 2.20$ per 10 .

oreganum. Yellow. $\$ .50$ each, $\$ 4.50$ per 10 .

reflexum (Jenny Stonecrop). Yellow; 8 to 10 in.; July and August.

$\$ .30$ each, $\$ 2.50$ per 10 .

sarmentosum (Stringy Stonecrop). Yellow ; 6 in.; May to July.

sexanglare (Hexagone Stonecrop). Yellow ; 3 in.

sioboldi (Siebold Stonecrop). Pink; 6 in.; August and September.

$\$ .35$ each, $\$ 3.00$ per 10 .

spectabile (Showy Stonecrop). Ros y pink; 1 to $11 / 2 \mathrm{ft}$; August and Sept. $\$ .25$ each, $\$ 2.20$ per 10 .

s. Brilliant. Rosy-pink; 1 to $1 \mathrm{I} / 2 \mathrm{ft}$; August and September.

$\$ .25$ each, $\$ 2.20$ per 10 .

s. variegata (Variegated Showy Stonecrop). Rosy-pink; 1 to $11 / 2 \mathrm{ft}$. ; August and September.

$\$ .25$ each, $\$ 2.20$ per 10 .

spurium. (S).

$\$ .25$ each, $\$ 2.20$ per 10 .

stoloniferum (True) (Running $\mathrm{S}$ t o n e crop). (S). Rosy-pink ; 4 in.; July and August.

ternatum minus.

wallichianum. (S)

$\$ 4.00$ each, $\$ 35.00$ per 10 .

HOUSELEEK (Sempervivum).

alberti. ( R). $\$ .25$ each, $\$ 2.20$ per 10 .

arachnoideum (Spiderweb Houseleek). (R). Bright red; 4 in. $\$ .25$ each, $\$ 2.20$ per 10 .

globiferum (Globe Houseleek). (R). Yellow ; 6 to 9 in. $\$ .25$ each, \$2.20 per 10 .

hirtum (cornutum) (Italian Houseleek). (R).

$\$ .25$ each, $\$ 2.20$ per 10 .

potsi. (R). Yellow; 6 in.

$\$ .25$ each, $\$ 2.20$ per 10 .

soboliferum (Hen and Chickens). (R). Yellow; 6 to 9 in.

$\$ .25$ each, $\$ 2.20$ per 10 .

tectorum (Roof Houseleek). (R). Red; 8 to $12 \mathrm{in}$.

$\$ .25$ each, \$2.20 per 10 .

t. violaceum (Violet Houseleek). (R).

Violet; $1 \mathrm{ft}$.

$\$ .25$ each, \$2.20 per 10 .

PRAIRIEMALLOW (Sidalcea).

Rosy Gem. Rose-pink: 3 ft.; June. 


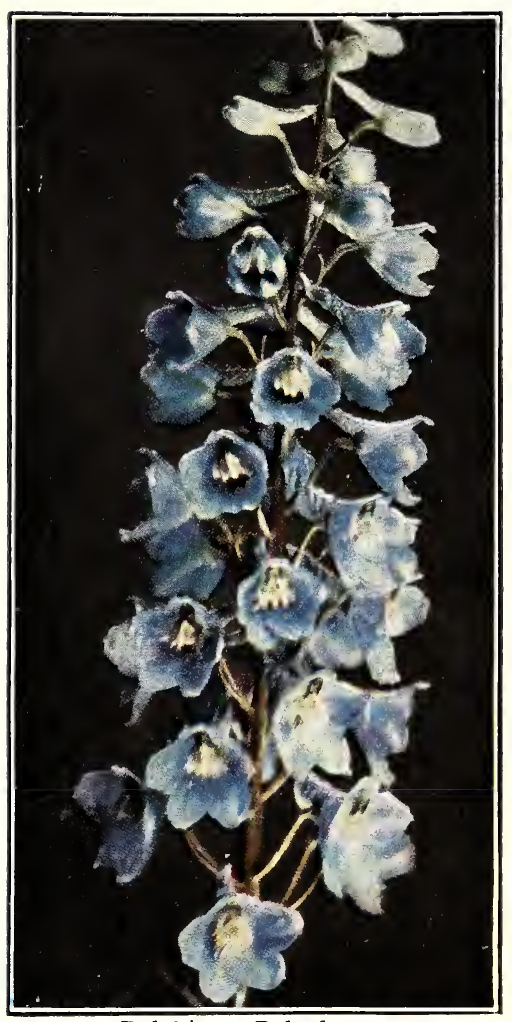

Delphinum Belıadonna.

\section{A Few Perennials in Color for You}
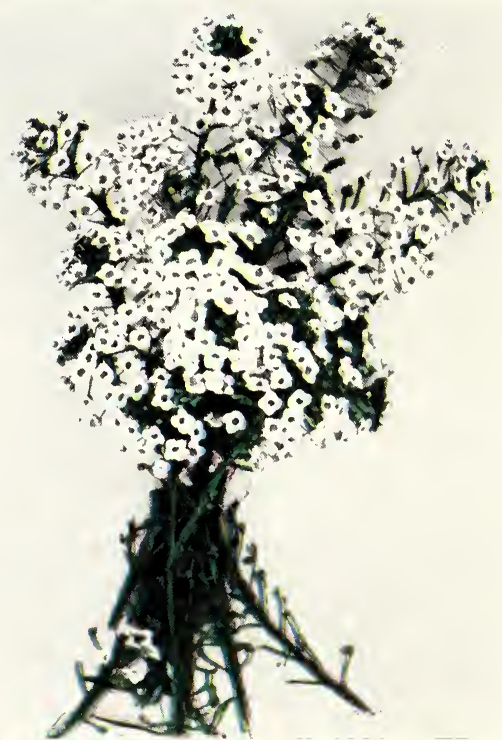

Alyssum Saxatile Compactum. See Page 25.

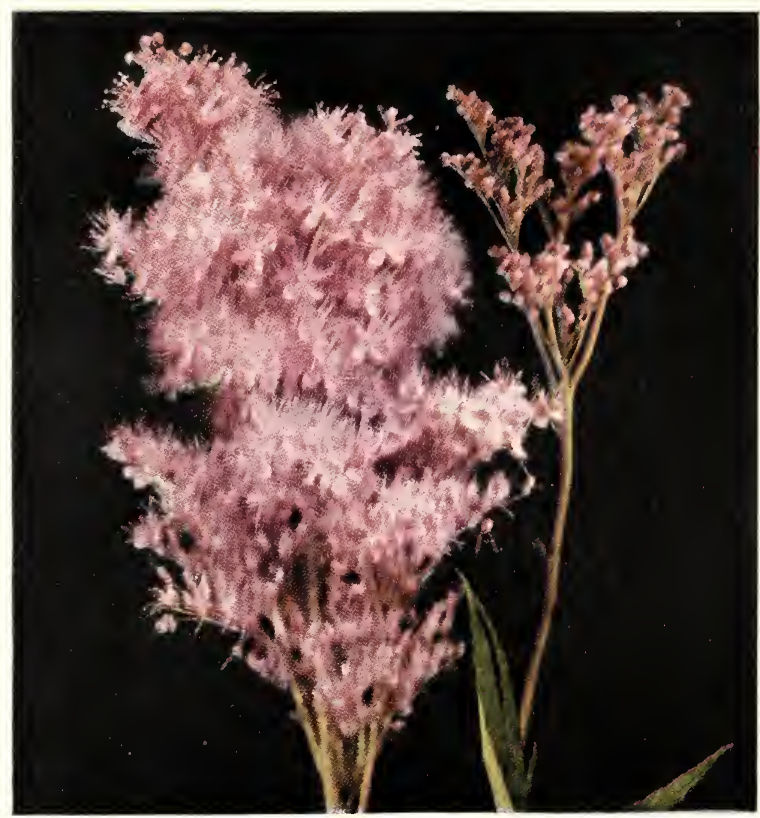

Astilbe Gloria. See Page 26. 
CATCHFLY (Silene).

alpestris (Alpine Catchfly). (R). White; 4 in. ; May and June. $\$ .35$ each, $\$ 3.00$ per 10 .

schafta (Schafta Catchfly). (R). Rosepink; 4 to 6 in.; June to September.

GERMANDER (Teucrium). orientale. ( $\mathrm{R})$. Blue; $8 \mathrm{in}$. $\$ .50$ each, $\$ 4.00$ per 10 .

MEADOWRUE (Thalictrum). aquilegifolium (Columbine Meadowrue). Cream; 2 to $3 \mathrm{ft}$.; May to July.

THERMOPSIS (Thermopsis).

mollis (Soft Thermopsis). Yellow; 2 to

$3 \mathrm{ft}$. ; May to August.

$\$ .40$ each, $\$ 3.00$ per 10 .

THYME (Thymus).

s e r p y ll u m (Mother-of-Thyme). (R). Lilac; 6 in.; July and August.

s. aureum. (R).

$\$ .35$ each, $\$ 3.00$ per 10 .

s. citriodorus (Lemon - scented Thyme). (R). Pink; 4 in. ; July and August.

s. lanuginosus (Wooly Thyme). (R). Reddish pink; 4 in.; August.

SPIDERWORT (Tradescantia).

virginiana (Virginia Spiderwort). Blue; 2 ft.; July and August.

GLOBEFLOWER (Trollius).

asiaticus (Siberian Globeflower). Orange ; 1 to $1 \mathrm{I} / 2 \mathrm{ft}$.; May and June.

$\$ .50$ each, $\$ 4.00$ per 10 .

europaeus (Common Globeflower). Lemonyellow; 1 to $1 \mathrm{I} / 2 \mathrm{ft}$.; May and August. $\$ .40$ each, $\$ 3.50$ per 10 .

Dwyer's Giant. Yellow; 2 to $2 \mathrm{I} / 2 \mathrm{ft}$; May to July. $\$ .50$ each, $\$ 4.00$ per 10 .

TUNICFLOWER (Tunica).

saxifraga (Saxifrage Tunicflower). (R). Pink; 6 in. ; all Summer.

s. alba (White Saxifrage Tunicflower). (R). White; 6 in. ; all Summer.

VALERIAN (Valeriana).

officinalis (Garden Heliotrope). Lavender ; $4 \mathrm{ft}$. : June.

MULLEIN (Verbascum).

densiflorum. Yellow; 4 to $6 \mathrm{ft}$.; June and July.

SPEEDWELL (Veronica).

\section{Suggestions for \\ Rock Garden Evergreens}

Chamaecyparis filifera aurea

Daphne cneorum

Euonymus radicans minimus

Juniperus chinensis pfitzeriana

Juniperus horizontalis

Juniperus sabina

Picea glauca conica

Pinus montana mughus

Taxus canadensis allioni (Allioni Speedwell). (R). Violet; 6 to 18 in. ; May to July.

$\$ .35$ each, $\$ 3.00$ per 10 .

longifolia subsessilis (Clump Speedwell). Blue; $2 \mathrm{ft}$.; July to September.

$\$ .40$ each, $\$ 3.50$ per 10 .

longifolia subsessilis, Blue Jay. Violet-

blue; 3 to $4 \mathrm{ft}$.; July to September.

$\$ .40$ each, $\$ 3.50$ per 10 .

repens (Creeping Speedwell). (R). Light blue; 3 to 4 in.; May and June.

$\$ .35$ each, $\$ 2.70$ per 10 .

spicata (Spike Speedwell). Violet-blue; 18 in.; June and July.

PERIWINKLE (Vinca).

minor (Common Periwinkle). (S). Bright blue; ground cover; Spring, Summer and Autumn.

Pot Grown....\$ .25 each, $\$ 2.20$ per 10 Field Grown .\$ $\$ 25$ each, $\$ 2.20$ per 10

m. a l b a (White Common Periwinkle). Same as above only white. $\$ .35$ each, $\$ 3.00$ per 10 .

VIOLET (Viola).

cornuta (Tufted Pansy). (R). Light blue; 8 in. : April to October.

cucullata (Blue M a r s h Violet). Dark blue; 8 in.; April and May.

$\$ .25$ each, $\$ 2.20$ per 10 .

Jersey Gem. (R). Violet blue; 8 in.; April to October.

$\$ .35$ each, $\$ 3.00$ per 10 .

Hybrids (Tufted Pansies). (R). 6 in.;

June to September.

Admiration. Dark blue.

Lutea. Yellow.

Mauve Queen. Reddish violet.

Purple Queen. Purple.

White Perfection. White.

$\$ .25$ each, $\$ 2.20$ per 10 .

odorata Single Russian (Sweet Violet). Blue; 6 in.; April to June.

o. White Czar. White; 6 in.; April to June.

YUCCA (Yucca).

filamentosa (Common Yucca). Creamy white ; 4 to $5 \mathrm{ft}$.; June and July.

2 years.......... \$ .30 each, $\$ 2.40$ per 10
3 years .........\$ .35 each, $\$ 300$ per 10
4 years...$\ldots$ each, $\$ 3.50$ per 10

\section{Anniversary \\ Perennial Collection No. 19}

3 Aconitum autumnale

3 Hemerocallis flava

3 Hibiscus moscheutos

3 Astilbe-Salland

3 Tradescantia virginiana

3 Gypsophila-Bristol Fairy

3 Platycodon grandiflora

21 Choice Perennials-A Distinctive Collection

Anniversary Special Offer ....\$6.85

Regular Price $\$ 8.70$. 


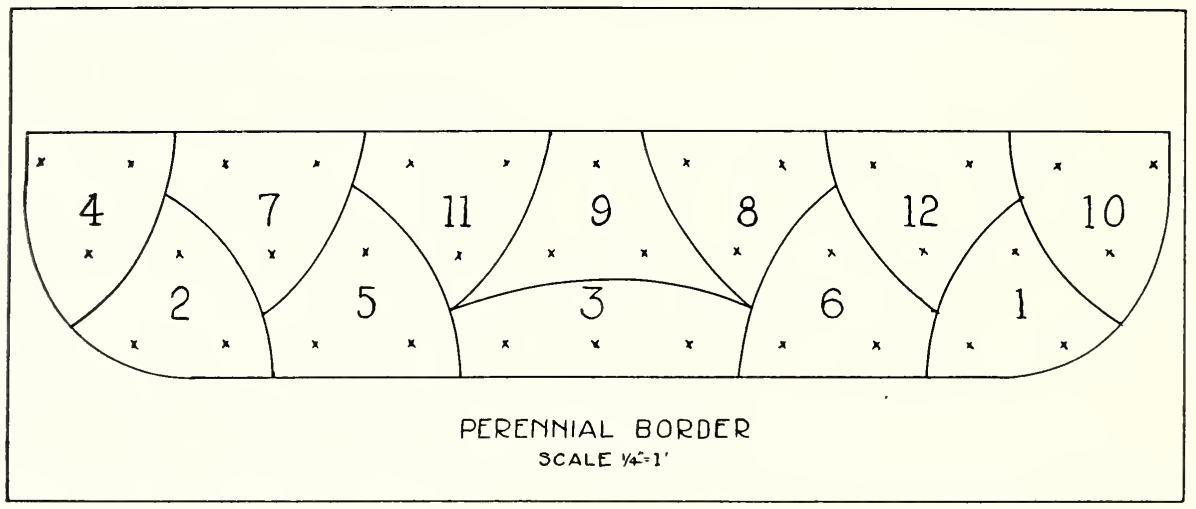

\section{Anniversary Perennial Border Collection}

\section{Anniversary Collection No. 18}

\section{For Diagram shown}

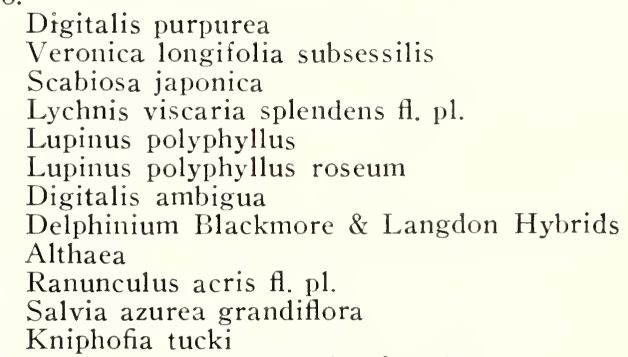

\section{Quick Reference List of Trees}

Red Maple

\section{For Quick Effect}

Western Catalpa

Norway Spruce

Red Pine

White Pine

Scotch Pine

Poplars

Willows

Mountain Ash

Honeylocust

To Attract Birds

Chokeberries

Dogwoods

Honeysuckles

Juniper
Flowering $\mathrm{Crab}$

Elderberries

Mulberries

For Street Planting

Norway Maple

Lindens

Elms

Tuliptree

Maidenhair-tree

Maples

For Fall Color

Ash

Birch

Oaks

Tuliptree

Sweetgum 


\section{Evergreens}

D ESERVEDLY, the use of evergreens for landscape effect is growing enormously, for they are year-round friends. There are low lying dwarf forms, conical varieties of all sizes, and tall, stately, columnar types, varying in color from sombre shades of green and gold to fresh gray-greens and deep blue-greens.

This year we can offer you the finest growth we have had in our history, trees that will respond to your plans for a formal or naturalistic planting.

Abbreviations: Suitable for Rock Gardens (R); Suitable for Sea Shore (S); Attracts Birds (B)

WHITE FIR (Abies concolor). A superb "showy" lawn specimen of stately, symmetrical growth. Foliage green to grayish blue.

5 to $6 \mathrm{ft}$.

$\$ 15.00$ each

4 to $5 \mathrm{ft}$ $\$ 12.00$ each

3 to $4 \mathrm{ft}$.

$\$ 95.00$ per 10

$2 \mathrm{r} / 2$ to $3 \mathrm{ft} \ldots \ldots . . \$ 8.00$ each, $\$ 7500$ per 10

2 to $2 \mathrm{r} / 2 \mathrm{ft}$........\$ 6.00 each, $\$ 55.00$ per 10 18 to $24 \mathrm{in}$.

$\$ 5.00$ each

SLENDER HINOKI CYPRESS (Chamaecyparis obtusa gracilis). Pyramidal in shape, with rich green feathery foliage.

2 to $3 \mathrm{ft}$

$\$ 5.00$ each

SAWARA RETINOSPORA (Chamaecyparis pisifera). Ideal for a formal specimen, tall with broad, flat, glossy green foliage.

5 to $6 \mathrm{ft}$.

$\$ 10.00$ each

4 to $5 \mathrm{ft}$............\$8.00 each, $\$ 75.00$ per 10

$3 \mathrm{r} / 2$ to $4 \mathrm{ft} \ldots \ldots . . \$ 6.50$ each, $\$ 60.00$ per 10

3 to $3 \mathrm{r} / 2 \mathrm{ft} \ldots \ldots . . \$ 5.00$ each, $\$ 45.00$ per 10

$2 \mathrm{t} / 2$ to $3 \mathrm{ft} . \ldots \ldots+\$ 4.00$ each, $\$ 35.00$ per 10

2 to $2 \mathrm{r} / 2 \mathrm{ft} \ldots \ldots . . \$ 3.50$ each, $\$ 30.00$ per 10

THREAD RETINOSPORA (Chamaecyparis p. filifera). Dense, dark $\mathrm{g} r$ ee $n$ thread-like pendulous branches of lovely light green foliage. A graceful low tree. $3 \mathrm{r} / 2$ to $4 \mathrm{ft}$......... $\$ 7.50$ each, $\$ 70.00$ per 10 3 to $3 \mathrm{r} / 2 \mathrm{ft}$........\$6.50 each, $\$ 6000$ per 10 $2 \mathrm{t} / 2$ to $3 \mathrm{ft} . \ldots \ldots . . \$ 5.50$ each, $\$ 50.00$ per 10 2 to $2 \mathrm{r} / 2 \mathrm{ft}$........\$4.50 each, $\$ 40.00$ per 10 18 to 24 in........\$350 each, $\$ 30.00$ per 10

G O L D E N THREAD RETINOSPORA (Chamaecyparis p. filifera aurea). Vividly golden foliage in the above form.
18 to 24 in.
$\$ 5.00$ each

15 to $18 \mathrm{in}$.

$\$ 3.50$ each

PLUME RETINOSPORA (Chamaecyparis p. plumosa). Soft, feathery branchings that respond to shearing. Excellent for formal work or as a hedge.

5 to $6 \mathrm{ft}$........\$12.00 each, $\$ 115.00$ per 10

4 to $5 \mathrm{ft} \ldots \ldots . . \$ 9.00$ each, $\$ 85.00$ per 10

$3 \mathrm{r} / 2$ to $4 \mathrm{ft} . \ldots . \$ 7.00$ each, $\$ 65.00$ per 10

3 to $3 \mathrm{r} / 2 \mathrm{ft} \ldots . . \$ 6.00$ each, $\$ 57.00$ per 10

$2 \mathrm{r} / 2$ to $3 \mathrm{ft} \ldots . \$ 4.50$ each, $\$ 40.00$ per 10

2 to $2 \mathrm{r} / 2 \mathrm{ft} . \ldots \$ 3.50$ each, $\$ 30.00$ per 10

18 to 24 in ... \$2.75 each. \$25.00 per 10
SILVERTIP RETINOSPORA (Chamaecyparis p. plumosa argentea). Greenish blue foliage with silver tips.

3 to $3 \mathrm{r} / 2 \mathrm{ft}$.

$2 \mathrm{r} / 2$ to $3 \mathrm{ft}$

2 to $2 \mathrm{r} / 2 \mathrm{ft}$

$\$ 7.00$ each $\$ 5.50$ each

18 to 24 in

$\$ 3.50$ each

GOLDENPLUME RETINOSPORA (Chamaecyparis p. plumosa aurea). (R). A strikingly individual form which makes an interesting contrast against the usual green of evergreens.

$4 \mathrm{r} / 2$ to $5 \mathrm{ft} \ldots \ldots \ldots$

4 to $4 \mathrm{r} / 2 \mathrm{ft} \ldots \ldots \ldots \ldots \ldots$ each

$3 \mathrm{t} / 2$ to $4 \mathrm{ft} \ldots \$ 50$ each, $\$ 60.00$ per 10

3 to $3 \mathrm{I} / 2 \mathrm{ft} \ldots \ldots 5.50$ each, $\$ 50.00$ per 10

$2 \mathrm{r} / 2$ to $3 \mathrm{ft} \ldots \ldots+. .50$ each, $\$ 40.00$ per 10

2 to $2 \mathrm{r} / 2 \mathrm{ft} \ldots \ldots 3 . . \ldots 0$ each, $\$ 3000$ per 10

18 to 24 in...... $\$ 2.75$ each, $\$ 25.00$ per 10

MOSS RETINOSPORA (Chamaecyparis p. squarrosa). Silvery blue in color, broadly pyramidal, soft and graceful.

$3 \mathrm{r} / 2$ to $4 \mathrm{ft} \ldots \ldots \ldots . .50$ each, $\$ 70.00$ per 10

3 to $3 \mathrm{r} / 2 \mathrm{ft} \ldots \ldots \ldots . . . \$ 0$ each, $\$ 60.00$ per 10

$2 \mathrm{r} / 2$ to $3 \mathrm{ft} \ldots \ldots 5.50$ each, $\$ 50.00$ per 10

2 to $2 \mathrm{I} / 2 \mathrm{ft} \ldots \ldots . . \$ 5.00$ each, $\$ 4500$ per 10

18 to 24 in....... $\$ 4.00$ each, $\$ 35.00$ per 10

W H I T E L E A F CHINESE JUNIPER

(Juniperus chinensis albovariegata). Compact, dense. Needle type foliage, dark steel gray-green with occasional yellowwhite tips.

2 to $2 \mathrm{t} / 2 \mathrm{ft}$. Spread ……..... $\$ 5.50$ each 18 to $24 \mathrm{in.} \mathrm{Spread \ldots \ldots ..........} \$ 5.00$ each

PFITZER JUNIPER (Juniperus c. pfitzeriana). (S). A success everywhere. This remarkable evergreen is as broad as it is tall; soft gray-green, feathery foliage.

$\begin{array}{lll}3 \mathrm{r} / 2 \text { to } 4 \mathrm{ft} \text {. Spread ........ } \$ 12.00 & \$ 115.00 \\ 3 \text { to } 3 \mathrm{r} / 2 \mathrm{ft} \text {. Spread......... } \$ 8.50 & \$ 80.00 \\ 2 \mathrm{r} / 2 \text { to } 3 \mathrm{ft} \text {. Spread......\$6.50 } & \$ 60.00 \\ 2 \text { to } 2 \mathrm{r} / 2 \mathrm{ft} \text {. Spread....... } \$ 5.00 & \$ 45.00 \\ 18 \text { to } 24 \mathrm{in} \text {. Spread.........\$3.50 } & \$ 33.00\end{array}$

GOLDEN JUNIPER (Juniperus communis aurea). (R). Brilliant gold e $\mathrm{n} \mathrm{hue}$ throughout season. Splendid for rockeries, or as contrast in front of evergreen borders.

2 to $2 \mathrm{r} / 2 \mathrm{ft}$. Spread ……......\$7.00 each 18 to 24 in. Spread................\$4.00 each

Five or more plants of one kind priced at the 10 rate. 
IRISH JUNIPER (Juniperus c. hibernica). (B). A tall columnar form of great dignity. Leaves are gray-green.

$3 \mathrm{t} / 2$ to $4 \mathrm{ft} \ldots \ldots . . \$ 6.00$ each, $\$ 55.00$ per 10 3 to $3 \mathrm{I} / 2 \mathrm{ft} \ldots \ldots . . . \$ 5.00$ each, $\$ 45.00$ per 10 $2 \mathrm{r} / 2$ to $3 \mathrm{ft} . \ldots \ldots+. \$ 4.00$ each, $\$ 36.00$ per 10 2 to $2 \mathrm{I} / 2 \mathrm{ft}$.........\$3.00 each, $\$ 27.00$ per 10 18 to 24 in.......\$2.50 each, $\$ 22.50$ per 10

SWEDISH JUNIPER (Juniperus c. suecica). (B). Another even taller columnar variety. Perfect for formal use. Prickly light green needles. May reach 10 to $12^{\prime}$. 4 to $5 \mathrm{ft} \ldots \quad \$ 7.50$ each, $\$ 70.00$ per 10 $3 \mathrm{r} / 2$ to $4 \mathrm{ft}$....... $\$ 6.50$ each, $\$ 60.00$ per 10 3 to $3 \mathrm{r} / 2 \mathrm{ft} \ldots \ldots \ldots 5.50$ each, $\$ 50.00$ per 10 $2 \mathrm{r} / 2$ to $3 \mathrm{ft} \ldots \ldots+\$ 4.50$ each, $\$ 40.00$ per 10 2 to $2 \mathrm{I} / 2 \mathrm{ft} \ldots \ldots 3.50$ each, $\$ 30.00$ per 10

UPRIGHT COMPACT SWEDISH JUNI-

PER (Juniperus c. suecica) (Compact Upright). Similiar to above but more compact.

$3 \mathrm{I} / 2$ to $4 \mathrm{ft} \ldots \ldots . . \$ 6.00$ each, $\$ 55.00$ per 10

3 to $3 \mathrm{~T} / 2 \mathrm{ft}$.......\$5.00 each, $\$ 45.00$ per 10

$2 \mathrm{t} / 2$ to $3 \mathrm{ft} \ldots \ldots+\ldots .00$ each, $\$ 35.00$ per 10

2 to $2 \mathrm{I} / 2 \mathrm{ft} \ldots \ldots . . \$ 3.00$ each, $\$ 25.00$ per 10

SPINY GREEK JUNIPER (Juniperus excelsa stricta). Steel blue, small, perfectly pyramidal tree of dense foliage.

$2 \mathrm{r} / 2$ to $3 \mathrm{ft} \ldots \ldots \ldots . . . \$ 6$ each, $\$ 54.00$ per 10 2 to $2 \mathrm{I} / 2 \mathrm{ft} \ldots \ldots . . \$ 5.00$ each, $\$ 45.00$ per 10 18 to 24 in....... $\$ 4.00$ each, $\$ 36.00$ per 10 15 to 18 in........\$3.00 each, $\$ 27.00$ per 10 12 to 15 in....... $\$ 2.00$ each, $\$ 1500$ per 10

CREEPING JUNIPER (Juniperus horizontalis). ( $R$ ). Unexcelled for rock gardens, slopes or banks because of its tendency to fairly hug the ground. Thrives in sandy soil.

$\begin{array}{lrr}18 \text { to } 24 \text { in. Spread .......... } \$ 4.50 & \$ 42.00 \\ 15 \text { to } 18 \text { in. Spread ...........\$3.50 } & \$ 33.00\end{array}$

WAUKEGAN JUNIPER (Juniperus $h$. douglasi). (RS). Deep green foliage in low growing spreading type. Exceptionally fine.

$\begin{array}{lll}2 \text { to } 2 \mathrm{I} / 2 \text { ft. Spread ........... } \$ 5.00 & \$ 4.00 \\ 18 \text { to } 24 \text { in. Spread.........\$4.00 } & \$ 36.00\end{array}$

SA V I N JUNIPER (Juniperus sabina). (SR). An interesting fan-like growth makes this evergreen invaluable for rockeries.

\begin{tabular}{|c|c|c|}
\hline Each & Per 10 & Per 100 \\
\hline o 3' Spread....\$6.00 & $\$ 54.00$ & \\
\hline $\begin{array}{l}2 \text { to } 2 \text { r } / 2 \text { ' Spread... } \$ 5.00 \\
18 \text { to } 24^{\prime \prime} \text { Spread..\$4.00 }\end{array}$ & $\begin{array}{l}\$ 45.00 \\
\$ 36.00\end{array}$ & \\
\hline 15 to $18^{\prime \prime}$ Spread.. $\$ 3.00$ & $\$ 27.00$ & $\$ 200.00$ \\
\hline 12 to $15^{\prime \prime}$ Spread.. $\$ 2.00$ & $\$ 15.00$ & $\$ 100.00$ \\
\hline
\end{tabular}

TAMARIX SAVIN JUNIPER (Juniperus s. tamariscifolia). (RS). Queer and fascinating in its wide spreading growth to
6 or 8 feet, with a height of only 6 inches. Blue green feathery foliage.

18 to $24 \mathrm{in.}$. Spread.................\$5.00 each

15 to 18 in. Spread..................\$4.00 each

GLOBE CHINESE JUNIPER (Juniperus virginalis globosa). ( $R$ ). Dwarf globeshape Chinese Juniper with dark green feathery foliage.

12 to 15 in. Spread …….......\$3.50 each

REDCEDAR (Juniperus virginiana). (BS).

Tall, slender, pyramidal tree needed in practically every planting. Very hardy.

7 to $8 \mathrm{ft}$.................................. $\$ 16.00$ each

6 to $7 \mathrm{ft} . \ldots \ldots \ldots \ldots \ldots . . . \ldots 12.00$ each

5 to $6 \mathrm{ft}$............\$9.00 each, $\$ 85.00$ per 10

4 to $5 \mathrm{ft} \ldots \ldots \ldots . . \quad \$ 6.50$ each, $\$ 60.00$ per 10

3 to $4 \mathrm{ft} \ldots \ldots+\$ 4.50$ each, $\$ 42.00$ per 10

2 to $3 \mathrm{ft}$...........\$3.50 each, $\$ 33.00$ per 10

SILVER REDCEDAR (Juniperus v. glauca). (BS). Outstandingly popular because of its silvery color and graceful feathery tipped branchlets.

$2 \mathrm{t} / 2$ to $3 \mathrm{ft}$........\$ $\$ 8.00$ each, $\$ 75.00$ per 10 2 to $2 \mathrm{I} / 2 \mathrm{ft} \ldots \ldots 6.00$ each, $\$ 55.00$ per 10

WHITE SPRUCE (Picea canadensis). (S).

A stately, densely growing tree of light green foliage, slightly tinged with blue. Pyramidal form retained for fifty years. $2 \mathrm{r} / 2$ to $3 \mathrm{ft} \ldots \ldots . . \$ 3.75$ each, $\$ 35.00$ per 10 2 to $21 / 2$ ft.......\$3.00 each, $\$ 27.00$ per 10 18 to 24 in.......\$2.25 each, $\$ 20.00$ per 10

NORWAY SPRUCE (Picea excelsa). (S). The usual Christmas Tree, vigorous and thoroughly dependable as a windbreak. hedge or screen.
5 to $6 \mathrm{ft}$.
$\$ 7.00$ each
4 to $5 \mathrm{ft}$. $\$ 5.50$ each, $\$ 50.00$ per 10
3 to $4 \mathrm{ft} \ldots \ldots \ldots . . . \$ 400$ each, $\$ 36.00$ per 10
2 to $3 \mathrm{ft} \ldots \ldots \ldots . . \$ 2.50$ each, $\$ 22.50$ per 10
18 to 24 in........ $\$ 1.50$ each, $\$ 12.00$ per 10

DWARF A L B E T A SPRUCE (Picea glauca conica). (RS). Low, dense, conical, and of exceptionally high merit for rockeries or for any place where a permanent low evergreen is desired.

27 to 30 in......\$8.00 each, $\$ 75.00$ per 10

24 to 27 in....... $\$ 7.00$ each, $\$ 65.00$ per 10

21 to 24 in........\$6.00 each, $\$ 55.00$ per 10

18 to 21 in........ $\$ 5.00$ each, $\$ 45.00$ per 10

15 to 18 in..........\$4.00 each, $\$ 36.00$ per 10

12 to 15 in.........\$3.50 each, $\$ 33.00$ per 10

9 to 12 in........ $\$ 3.00$ each, $\$ 27.00$ per 10

BLACK SPRUCE (Picea mariana). (S).

The native Black Spruce. Slender, almost pendulous branches, very distinctive.

$2 \mathrm{r} / 2$ to $3 \mathrm{ft} \ldots \ldots . . \$ 3.50$ each, $\$ 33.00$ per 10
2 to $2 \mathrm{t} / 2 \mathrm{ft} \ldots \ldots \ldots . . \$ 3.00$ each, $\$ 25.00$ per 10
18 to $24 \mathrm{in} \ldots \ldots . . \$ 200$ each, $\$ 15.00$ per 10




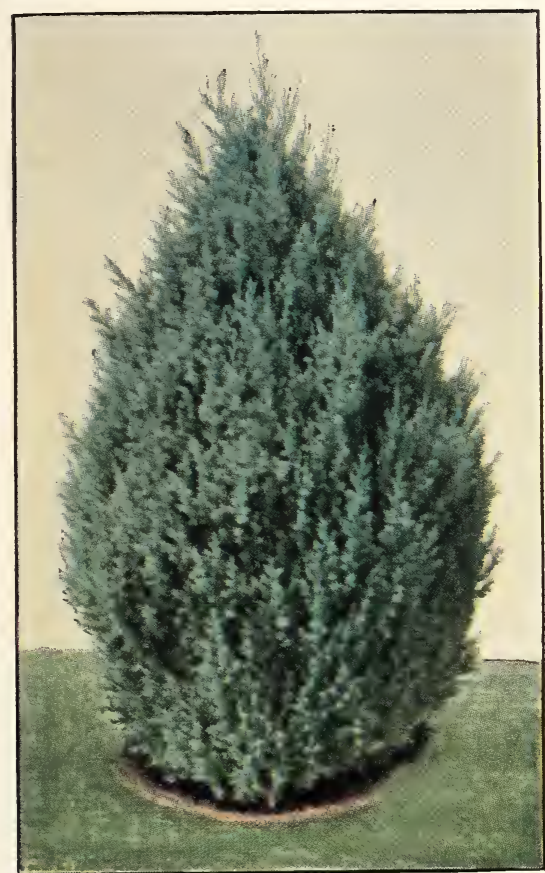

Juniperus Excelsa Stricta (Greek Juniper)

COLORADO SPRUCE (Picea pungens).

(S). Noted for hardiness, symmetry, light green to blue foliage.
5 to $6 \mathrm{ft}$.

$\$ 15.00$ each

4 to $5 \mathrm{ft}$.

$\$ 12.00$ each

$3 \mathrm{t} / 2$ to $4 \mathrm{ft}$

$\$ 10.00$ each

3 to $3 \mathrm{t} / 2 \mathrm{ft}$.

$2 \mathrm{t} / 2$ to $3 \mathrm{ft} . \ldots . . . \$ 6.00$ each, $\$ 55.00$ per 10

2 to $2 \mathrm{r} / 2 \mathrm{ft} \ldots \ldots . . \$ 4.50$ each, $\$ 40.00$ per 10

18 to 24 in........ $\$ 3.50$ each, $\$ 33.00$ per 10

BLUE COLORADO SPRUCE (Picea p. glauca). (S). The king of Spruces, some say the ultimate in beautiful evergreens. Very blue in color.
4 to $5 \mathrm{ft}$.
$3 \mathrm{t} / 2$ to $4 \mathrm{ft}$
$\$ 18.00$ each
3 to $3 \frac{1}{2} \mathrm{ft}$.
$\$ 15.00$ each
$2 \mathrm{t} / 2$ to $3 \mathrm{ft}$. $\$ 12.50$ each 2 to $2 \frac{1}{2} \mathrm{ft} \ldots \ldots . . . \$ 8.00$ each, $\$ 7500$ per 10 18 to 24 in........\$ 6.50 each, $\$ 60.00$ per 10

SWISS STONE PINE (Pinus cembra). A choice growth, thickly foliaged with gray green needles. Fine conical shape.
2 to $3 \mathrm{ft}$
$\$ 8.00$ each

JAPANESE RED PINE (Pinus densiflora). (S). Long light green needles; branchlets orange-yellow and chestnutbrown buds.

$$
\begin{aligned}
& 3 \text { to } 4 \mathrm{ft} \ldots \ldots \ldots \ldots \ldots \ldots \\
& 2 \text { to } 3 \mathrm{ft} \ldots \ldots
\end{aligned}
$$

MUGHO PINE (Pinus montana mughus). (S). This dwarf evergreen achieves immediate interest in your planting. Very low, shrubby, compact, and hardy. The true type; highly recommended.

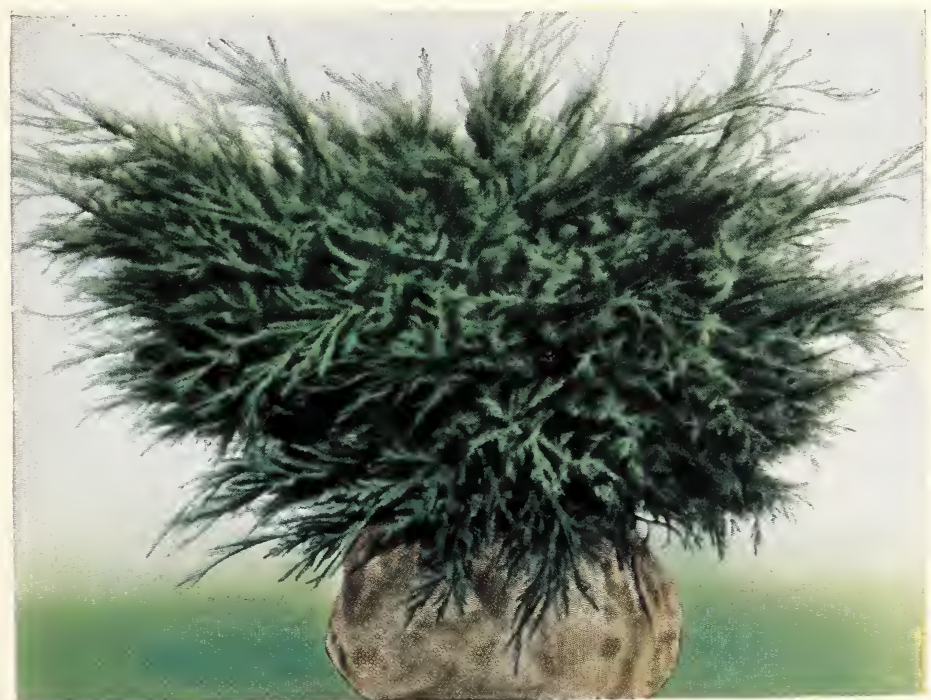

Juniperus Pfitzeriana.

Our Club Plan of Payment is convenient and practical. 
Each Per 10 Per 100 3 to $3 \mathrm{I} / 2 \mathrm{ft}$. Spread.......\$15.00 $\$ 140.00$ $2 \mathrm{r} / 2$ to $3 \mathrm{ft}$. Spread.........\$10.00 $\$ 90.00$ 2 to $21 / 2 \mathrm{ft}$. Spread.........\$7.50 \$7 $\$ 7.00$ 18 to 24 in. Spread.........\$ $\$ 4.00 \$ 36.00$ 15 to 18 in. Spread....... \$3.50 \$30.00 12 to 15 in. Spread......\$ $\$ 2.75 \$ 25.00$

AUSTRIAN PINE (Pinus nigra). (S). A rugged, stately Pine, rapid in growth, very hardy.

2 to $3 \mathrm{ft} \ldots \ldots \ldots . . \$ 4.50$ each, $\$ 42.00$ per 10

RED PINE (Pinus resinosa). Light green, long needled foliage, with reddish brown bark; graceful and hardy.

3 to $4 \mathrm{ft} \ldots \ldots \ldots 5.00$ each, $\$ 45.00$ per 10

2 to $3 \mathrm{ft} \ldots \ldots \ldots 3.00$ each, $\$ 27.00$ per 10

WHITE PINE (Pinus strobus). (S). The largest of the cone bearing Pines; flexible, long needles, white underneath; dignified as a lawn specimen.

5 to $6 \mathrm{ft} \ldots \ldots \ldots \ldots$ each
4 to $5 \mathrm{ft} \ldots \ldots \ldots . . \$ 6.00$ each, $\$ 55.00$ per 10
3 to $4 \mathrm{ft} \ldots \ldots \ldots . \$ 4.00$ each, $\$ 36.00$ per 10

SCOTCH PINE (Pinus sylvestris). (S).

A picturesque rather than beautiful tree, seldom grows straight, oblique branches; quick growing and hardy.

5 to $6 \mathrm{ft}$........ $\$ 8.00$ each, $\$ 75.00$ per 10

4 to $5 \mathrm{ft} \ldots \ldots . . \$ 5.50$ each, $\$ 50.00$ per 10

3 to $4 \mathrm{ft} \ldots \ldots . . \$ 3.50$ each, $\$ 33.00$ per 10

2 to $3 \mathrm{ft} \ldots \ldots \ldots . . \$ 2.50$ each, $\$ 22.50$ per 10

DOUGLAS FIR (Pseudotsuga douglasi).

Characteristic of both Spruces and Hemlocks. A magnificent tree for use as a lawn specimen.

4 to $5 \mathrm{ft} \ldots \ldots . \$ 8.50$ each, $\$ 80.00$ per 10
3 to $4 \mathrm{ft} \ldots \ldots . \$ 6.00$ each, $\$ 55.00$ per 10
2 to $3 \mathrm{ft} \ldots \ldots \ldots . \$ 4.50$ each, $\$ 40.00$ per 10

CANADA YEW (Taxus canadensis). Low spreading, with thrifty dark green foliage, changing to bronze in winter with crimson berries. Thrives in partial shade.

\begin{tabular}{|c|c|c|}
\hline to $2 \mathrm{I} / 2 \mathrm{ft}$. Spread. & $\begin{array}{r}\text { Each } \\
\$ 4.50\end{array}$ & Per 10 \\
\hline 18 to 24 in. Spread. & $\$ 3.50$ & $\$ 33.00$ \\
\hline 15 to 18 in. Spread. & $\$ 2.50$ & $\$ 21.00$ \\
\hline 12 to $15 \mathrm{in.}$ Spread. & $\$ 2.00$ & $\$ 18.00$ \\
\hline
\end{tabular}

J A P A N E E YEW (Taxus cuspidata). (BS). Like the above, only slow growing, dark green, almost black foliage, retaining its color throughout the Winter; spreading type.

2 to $2 \mathrm{I} / 2 \mathrm{ft}$.

$\$ 7.50$ eacli

18 to 24 in.......\$5.00 each, $\$ 4500$ per 10

15 to 18 in.......\$3.75 each, $\$ 35.00$ per 10

12 to 15 in...... $\$ 3.00$ each, $\$ 25.00$ per 10

D W A R JAPANESE YEW (Taxus c. nana). (SR). Upright compact form, with short, dark green foliage throughout year. Odd appearing, but grows old gracefully.

21 to $24 \mathrm{in}$.

$\$ 12.00$ each

18 to 21 in

$\$ 8.00$ each

15 to 18 in........\$5.00 each, $\$ 45.00$ per 10

12 to 15 in......... $\$ 4.00$ each, $\$ 36.00$ per 10

S P R E A I N G DWARF JAPANESE YEW (Taxus c. nana). (SR). Like the above, only low growing instead of pyramidal. Very hardy.

18 to 21 in. Spread.

$\$ 8.00$ each

15 to 18 in. Spread...................\$5.00 each

12 to 15 in. Spread..................\$4.00 each

AMERICAN ARBORVITAE (Thuja occidentalis). (S). Perfect for ornamental hedges. Responds to clipping; dense columnar growth, flattened lace-like sprays.

5 to $6 \mathrm{ft}$......... $\$ 7.50$ each, $\$ 70.00$ per 10

4 to $5 \mathrm{ft}$...........\$5.50 each, $\$ 50.00$ per 10

3 to 4 ft............\$4.00 each, $\$ 35.00$ per 10

2 to $3 \mathrm{ft}$...........\$2.50 each, $\$ 21.00$ per 10

P A R S N'S ARBORVITAE (Thuja oc. compacta). A dwarf form, dense growth.

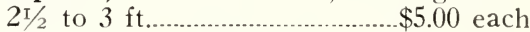
2 to $2 \mathrm{r} / 2 \mathrm{ft} . \ldots . . \$ 4.00$ each, $\$ 36.00$ per 10 18 to 24 in...... $\$ 3.50$ each, $\$ 30.00$ per 10

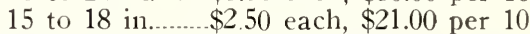

DOUGLAS PYRAMIDAL ARBORVITAE

(Thuja oc. douglasi pyramidalis). (S). Dark foliage in perfect, pyramidal form. Excellent for formal or parterre garden effects.

5 to $6 \mathrm{ft} \ldots \ldots . . \$ 9.00$ each, $\$ 87.00$ per 10

4 to $5 \mathrm{ft} \ldots \ldots . . \$ 7.00$ each, $\$ 65.00$ per 10

3 to $4 \mathrm{ft} \ldots \ldots \ldots$....... $\$ 5.00$ each, $\$ 48.00$ per 10

$2 \mathrm{I} / 2$ to $3 \mathrm{ft} . \ldots . . \$ 4.25$ each, $\$ 37.50$ per 10

2 to $2 \mathrm{I} / 2 \mathrm{ft} \ldots \ldots . . \$ 3.50$ each, $\$ 33.00$ per 10

TOM THUMB ARBORVITAE (Thuja oc. ellwangeriana). Slow g r o w in g, low, broad, compact variety. Soft, light green, feathery foliage.

4 to $4 \mathrm{r} / 2 \mathrm{ft} \ldots \ldots 7.50$ each, $\$ 70.00$ per 10 $3 \mathrm{I} / 2$ to $4 \mathrm{ft} . . . . . \$ 6.50$ each, $\$ 60.00$ per 10 3 to $3 \mathrm{r} / 2 \mathrm{ft} \ldots \ldots . \$ 5.50$ each, $\$ 52.00$ per 10 $2 \mathrm{I} / 2$ to $3 \mathrm{ft} \ldots \ldots . \$ 4.50$ each, $\$ 42.00$ per 10 2 to $2 \mathrm{r} / 2 \mathrm{ft}$........ $\$ 4.00$ each, $\$ 35.00$ per 10 18 to 24 in.......\$3.00 each, $\$ 27.00$ per 10

THREADLEAF ARBORVITAE ( $T h u j a$ oc. filiformis). Unique variety, with long thread-like foliage. Distinctly Japanese in effect.

18 to 24 in. $\$ 8.00$ each

A M E R I C A N GLOBE ARBORVITAE (Thuja oc. globosa). (RS). Splendid for formal effects and rockeries. A dense ball-like form.

2 to $2 \mathrm{r} / 2 \mathrm{ft} \ldots \ldots . . \$ 4.00$ each. $\$ 35.00$ per 10 18 to 24 in........\$3.00 each, $\$ 27.00$ per 10 15 to 18 in...... $\$ 250$ each, $\$ 22.50$ per 10 12 to 15 in....... $\$ 2.00$ each, $\$ 18.00$ per 10 
HOVEY A RBOR V I T A E (Thuja oc. hoveyi). A somewhat dwarf form of fresh light green color, slightly golden.

3 to $3 \mathrm{r} / 2 \mathrm{ft}$........\$4.50 each, $\$ 40.00$ per 10 $2 \mathrm{r} / 2$ to $3 \mathrm{ft} . \ldots \ldots . . \$ 3.75$ each, $\$ 35.00$ per 10 2 to $2 \mathrm{r} / 2 \mathrm{ft} . \ldots \ldots . . \$ 2.75$ each, $\$ 25.00$ per 10 18 to 24 in.......\$2 $\$ 50$ each, $\$ 22.50$ per 10 15 to 18 in........\$2.00 each, $\$ 18.00$ per 10

GEORGE P E A B D Y ARBORVITAE (Thuja oc. lutea). A beautiful pyramidal variety with bright yellow or golden foliage.

4 to $5 \mathrm{ft}$...........\$7.00 each, $\$ 6500$ per 10

3 to $4 \mathrm{ft} \ldots \ldots . . . \$ 5.50$ each, $\$ 50.00$ per 10

2 to $3 \mathrm{ft}$........... $\$ 4.50$ each, $\$ 40.00$ per 10

A M E R C A N PYRAMIDAL ARBORVITAE (Thuja oc. pyramidalis). (S). Slender, columnar growth of bright rich green hues. Unsurpassed for formal plantings.

6 to $7 \mathrm{ft}$.......\$12.00 each, $\$ 115.00$ per 10 $5 \mathrm{r} / 2$ to $6 \mathrm{ft}$... $\$ 10.00$ each, $\$ 95.00$ per 10 5 to $5 \mathrm{I} / 2 \mathrm{ft} \ldots \ldots . \$ 9.00$ each, $\$ 85.00$ per 10 $4 \mathrm{r} / 2$ to $5 \mathrm{ft}$......\$ 8.00 each, $\$ 7500$ per 10 4 to $4 \mathrm{r} / 2 \mathrm{ft} \ldots \ldots 7.00$ each, $\$ 65.00$ per 10 $3 \mathrm{I} / 2$ to $4 \mathrm{ft}$.....\$ $\$ 6.00$ each, $\$ 55.00$ per 10 3 to $3 \mathrm{r} / 2 \mathrm{ft} \ldots \ldots . \$ 500$ each, $\$ 45.00$ per 10 $2 \mathrm{I} / 2$ to $3 \mathrm{ft} . \ldots . . \$ 4.00$ each, $\$ 36.00$ per 10 2 to $21 / 2 \mathrm{ft}$.....\$ $\$ 3.50$ each, \$33.00 per 10

REID ARBORVITAE (Thuja oc. reidi). Bushy form, with short leaves.

$2 \mathrm{r} / 2$ to $3 \mathrm{ft} . \ldots \ldots . \$ 6.50$ each, $\$ 60.00$ per 10 2 to $2 \mathrm{r} / 2 \mathrm{ft} \ldots \ldots . . \$ 5.50$ each, $\$ 52.00$ per 10 18 to 24 in......\$ $\$ 4.50$ each, $\$ 42.00$ per 10

ROSENTHAL ARBORVITAE (Thuja oc. rosenthali). Noted for its fine columnar form and deep green color. Very fine.

5 to $5 \mathrm{r} / 2 \mathrm{ft}$. $\$ 15.00$ each $4 \mathrm{r} / 2$ to $5 \mathrm{ft}$. $\$ 12.00$ each

4 to $4 \mathrm{I} / 2 \mathrm{ft} . \ldots . . \$ 10.00$ each, $\$ 96.00$ per 10 $3 \mathrm{r} / 2$ to $4 \mathrm{ft} \ldots \ldots . \$ 8.50$ each, $\$ 80.00$ per 10 3 to $3 \mathrm{r} / 2 \mathrm{ft} . \ldots \ldots . \$ 7.00$ each, $\$ 66.00$ per 10 $2 \mathrm{r} / 2$ to $3 \mathrm{ft}$......\$ $\$ 6.00$ each, $\$ 57.00$ per 10 2 to $2 \mathrm{I} / 2 \mathrm{ft} . . . . \$ 5.00$ each, $\$ 48.00$ per 10 18 to 24 in......\$ 4.00 each, $\$ 36.00$ per 10

VERVAENE ARBORVITAE (Thuja oc. vervaeneana). (S). Pyramidal habit with rich bronze color in Winter.
5 to $6 \mathrm{ft}$...

4 to $5 \mathrm{ft}$.

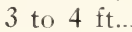

2 to $3 \mathrm{ft} .$.

$\$ 10.00$ each

18 to 24 in $\$ 8.00$ each, $\$ 76.00$ per 10 $\$ 6.00$ each, $\$ 57.00$ per 10 $\$ 4.00$ each, $\$ 36.00$ per 10 $\$ 3.00$ each, $\$ 25.00$ per 10

WARE ARBORVITAE (Siberian) (Thuja oc. w a rea na). (S). A very desirable broadly pyramidal variety, with shiny blue-green foliage. Excellent dense hedge plant.

$3 \mathrm{I} / 2$ to $4 \mathrm{ft}$...... $\$ 8.00$ each, $\$ 75.00$ per 10 3 to $31 / 2$ ft......\$7.00 each, $\$ 65.00$ per 10 $2 \mathrm{I} / 2$ to $3 \mathrm{ft} \ldots \ldots . \$ 5.00$ each, $\$ 45.00$ per 10 2 to $2 \frac{1}{2} \mathrm{ft} \ldots \ldots . \$ 4.00$ each, $\$ 36.00$ per 10 18 to 24 in.......\$3.50 each, $\$ 33.00$ per 10

WOODWARD ARBORVITAE (Thuja oc. woodwardi). Outstandingly satisfactory, maintains its globular form of about three feet in height and diameter.

2 to $21 / 2$ ft.......\$3.50 each, $\$ 30.00$ per 10 18 to 24 in....... $\$ 2.50$ each, $\$ 22.50$ per 10 15 to $18 \mathrm{in} . . . . . \$ 2.00$ each, $\$ 17.50$ per 10 12 to $15 \mathrm{in} . . . . \$ 1.50$ each, $\$ 12.50$ per 10

ORIENTAL ARBORVITAE (Thuja orientalis). Bright olive-green foliage in broadly pyramidal shape; less hardy than the above varieties.

$21 / 2$ to $3 \mathrm{ft} \ldots \ldots . \$ 3.25$ each, $\$ 27.00$ per 10 2 to $21 / 2$ ft.......\$2.75 each, $\$ 25.00$ per 10 18 to 24 in......\$2.25 each, $\$ 20.00$ per 10

\section{CANADA HEMLOCK (Tsuga canadensis)}

Handsome, graceful as specimen tree or for a hedge.

5 to $6 \mathrm{ft} \ldots \ldots \$ 14.00$ each, $\$ 135.00$ per 10 + to $5 \mathrm{ft}$........\$10.00 each, $\$ 95.00$ per 10 $3 \mathrm{r} / 2$ to $4 \mathrm{ft} \ldots \$ 8.00$ each, $\$ 75.00$ per 10 3 to $3 \mathrm{I} / 2 \mathrm{ft}$....\$ 6.00 each, $\$ 55.00$ per 10 $2 \mathrm{r} / 2$ to $3 \mathrm{ft} \ldots \$ 4.50$ each, $\$ 42.00$ per 10 2 to $2 \mathrm{r} / 2 \mathrm{ft} \ldots \$ 3.50$ each, $\$ 33.00$ per 10 18 to $24 \mathrm{in}$....\$2 2.50 each, $\$ 21.00$ per 10

CAROLINA HEMLOCK (Tsuga caroliniana). Dark dense tufted foliage sweeping gracefully to the ground. Tall and hardy.

5 to $6 \mathrm{it}$.

$\$ 15.00$ each

4 to $5 \mathrm{ft}$.

$3 \mathrm{to}+\mathrm{ft}$. $\$ 1000$ each $\$ 6.00$ each

\section{$\mathrm{T}$}

HE CULTIVATED EVERGREENS, by L. H. Bailey. Authorities call this "the only authoritative book on evergreens." Shows how to use evergreens (conifers and broad-leaves) in the landscape; how to plant and how to propagate them; how to control insects and diseases; and how to identify all the species and varieties. 162 illustrations, 434 pages.

Sent free as a premium for order of $\$ 30.00$ worth of

Evergreens from this catalog. 


\section{Anniversary Evergreen Foundation Planting Collections}

To soften and accentuate lines or conceal unsightly foundation work, nothing is more effective than a suitable foundation planting. With the suggestions on our diagrams, our collections may be easily adapted to your home. They will help set the picture in the frame.

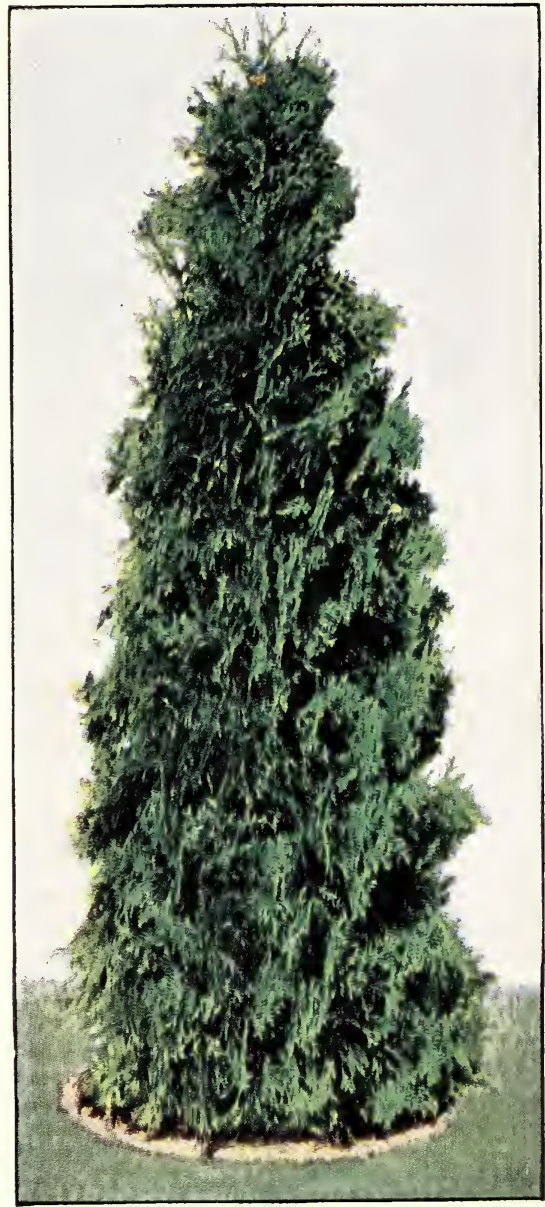

Thuja Pyramidalis (Pyramidal Arborvitae). See Page 40.

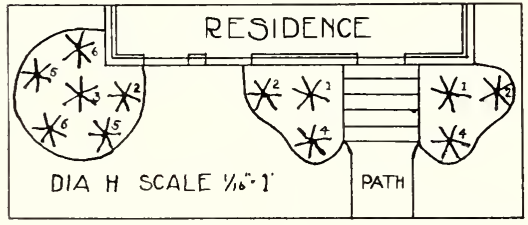

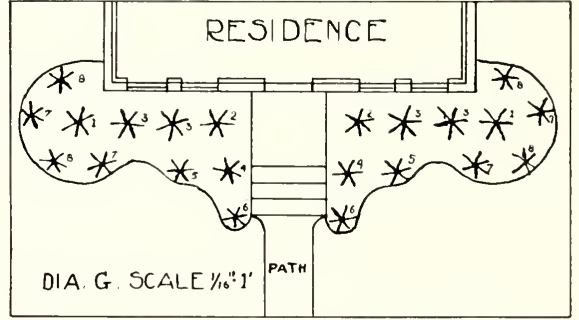

Anniversary Collection No. 14

Diagram G

Plant- No. of ing Key Plants

12 Chamaecyparis p. plumosa, $3^{1 / 2}-4^{\prime}$

22 Thuja oc pyramidalis, $3 \frac{1}{2}-t^{\prime}$

34 Thuja oc. wareana, $2 \frac{1}{2}-3^{\prime}$

42 Taxus cuspidata, 12-15"

52 Juniperus ex. stricta, 18-24"

62 Picea glauca conica, 18-21'

74 Thuja oc. globosa, 18-24"

84 Juniperus sabina, 15-18"

22 Hardy, Beautiful Evergreens. An exceptionally attractive and complete selection.

Anniversary Special Offer . \$66.00

Regular Price, $\$ 82.00$

Anniversary Collection No. 15 Diagram $\mathrm{H}$

Plant. No, of ing Key Plants

12 Juniperus suecica, $3 \frac{1}{2}-4^{\prime}$

23 Thuja wareana, $2 \mathrm{I} / 2-3^{\prime}$

31 Chamaecyparis p. plumosa, $3-3^{1} / 2^{\prime}$

42 Juniperus ex. stricta, 15-18"

52 Pinus mughus, 15-18"

62 Thuja globosa, 15-18"

12 Hardy Plants. These make a delightful setting.

Anniversary Special Offer . $\$ 39.75$

Regular Price, $\$ 52.00$ 


\section{Evergreen Shrubs}

THESE broad-leaved evergreens grow best in shady places. Besides being of value as foundation plants, along streams and under trees, some have delightful flowering habits.

Abbreviations: Suitable for Rock Gardens (R); Suitable for Sea Shore (S); Attracts Birds (B).

COMPACT HEATHER (Calluna vulgaris compacta). (R). A dwarf, compact variety of heather with tiny rosy pink flowers. Requires a well drained acid soil.

6 to 8 in.......... $\$ .75$ each, $\$ 6.00$ per 10

HAMMOND WHITE HEATHER (Calluna v. alba hammondi). (R). Low, bushy shrub, with slender spikes of delicate white flowers.

6 to 8 in $\$ . \quad 75$ each, $\$ 6.00$ per 10

ROSE DAPHNE (Daphne cneorum). (R). An exquisite dwarf bush with fragrant rich pink blossoms in May and August.

10 to 12 in....... $\$ 2.00$ each, $\$ 1800$ per 10

8 to 10 in........\$1.50 each, $\$ 14.00$ per 10

6 to 8 in......\$1.00 each, $\$ 9.00$ per 10

4 to 6 in......\$ $\$ .75$ each, $\$ 7.00$ per 10

CORSICAN HEATH (Erica stricta). (R).

Grows erect to height of about $2 \mathrm{ft}$; ; covered with rosy purple flowers.

4 to 6 in........ $\$ .75$ each, $\$ 6.00$ per 10

CORNISH HEATH (Erica vagans). (R). Flowers purplish red in August and September. Grows about one foot in height. 4 to 6 in............ $\$ .75$ each, $\$ 6.00$ per 10

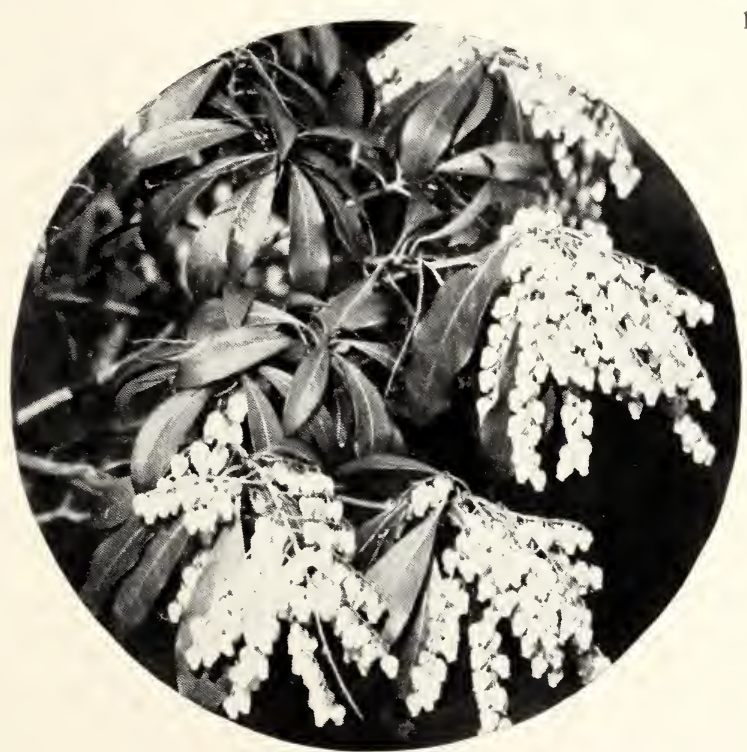

Mountain Andromeda.
GLOSSY WINTERCREEPER (E u o $\mathrm{y}$ mus radicans carrieri). Sturdy, largeleaved variety that readily climbs trees or walls. Trimmed, it forms an attractive hedge.

4 years.......... $\$ 1.50$ each, $\$ 12.50$ per 10

3 vears............\$1.00 each, \$ 8.00 per 10

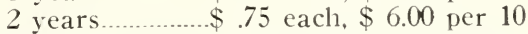

BRONZE WINTER CREEPER (Euonymus r. colorata). Charming bronze foliage in Winter. A rapid grower.

3 years _......... \$ .90 each, $\$ 7.50$ per 10

2 years \$ .60 each, $\$ 5.00$ per 10

BABY WINTERCREEPER (Euonymus $r$. minimus). Similar to radicans, except leaves are smaller and growth shorter.

2 years $\$ .75$ each, $\$ 6.50$ per 10

BIGLEAF WINTERCREEPER (Euonymus r. vegetus). As a ground cover this variety is splendid with its roundish leaves and orange-scarlet berries.

5 years........... $\$ 2.00$ each, $\$ 1800$ per 10

4 years.............\$1.50 each, $\$ 13.50$ per 10

3 years _......... $\$ 1.00$ each, $\$ 8.00$ per 10

2 years ........... \$ .75 each, $\$ 6.00$ per 10

We have a few larger and heavier plants from $\$ 3.00$ to $\$ 5.00$ each.

INKBERRY (Ilex glabra). A dense shrub with glossy black berries in dark green oval foliage. Excellent in shady locations.

$$
\begin{aligned}
& 2 \text { to } 2 \mathrm{I} / 2 \mathrm{ft} \ldots \ldots \ldots \\
& 18 \text { to } 24 \mathrm{in} \ldots \mathrm{s} .00 \mathrm{each}
\end{aligned}
$$

AMERICAN HOLLY (Ilex opaca). An increasingly popular slow growing tree, deservedly so, for it is charming with its large, shiny, thorny leaves and red berries.

3 in. pots, $\$ 1.00$ each, $\$ 9.00$ per 10

MOUNTAIN LAUREL (Kalmia latifolia). Sturdy growth in both its glossy green clustered leaves and profusion of pink and white blossoms.

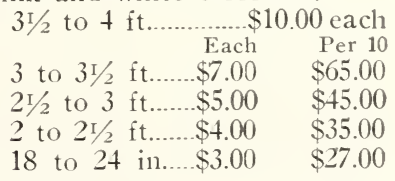

Write for special prices on 25 or more of a kind. 
DROOPING LEUCOTHOE (Leucothoe catesbaei). (R). Graceful, pendulous branches of heavy, shining green foliage; profuse creamy white delicate blossoms in the Spring. Excellent choice for shady location.

18 to 24 in........\$3.50 each, $\$ 33.00$ per 10

15 to 18 in.......\$2.50 each, $\$ 22.50$ per 10

12 to 15 in....... \$2.00 each, $\$ 1800$ per 10

JAPANESE PACHYSANDRA (Pachysandra terminalis). As a ground covering where grass will not grow, this evergreen is inimitable. In the Spring nosegays of lovely white blossoms appear through the green.

Field Grown .......\$.35 each, $\$ 2.50$ per 10 3 in. Pots_........ \$ .30 each, \$2 20 per 10
MOUNTAIN ANDROMEDA (Pieris floribunda). (R). Nodding flower clusters in white along a slender stem. Luxuriant, small dark green leaves. We recommend it highly.

18 to 24 in....... $\$ 6.00$ each, $\$ 55.00$ per 10

15 to 18 in....... $\$ 4.00$ each, $\$ 36.00$ per 10

12 to 15 in........\$3.00 each, $\$ 27.00$ per 10

COMMON PERIWINKLE (Vinca minor). (S). Used as a ground cover in shaded spots. Profuse bright blue petaled flowers in Spring and throughout the Summer and Autumn.

Pot Grown ….....\$ 25 each, $\$ 2.20$ per 10 Field Grown.....\$ .25 each, $\$ 2.20$ per 10

\section{Rhododendrons}

T HE climax in beauty and sheer loveliness is reached in this family. These broadleaved evergreens give one the impression of deep seated strength. Their leaves are glossy, long, tapering and richly green. Their blossoms are luxuriantly massed in clusters of fresh, delightful colors.

Along paths or drives, or as informal plantings for garden or lawn, they give the utmost pleasure.

They ask one thing in return, that they be planted in a decidedly acid soil. We can help you make sure of this.

HYBRID RHODODENDRONS. Mixed. These plants are grown from seeds of Hybrid Rhododendrons, shading from red, pink, to white. They grow much stronger and bushier than the grafted hybrids, and are perfectly hardy.

2 to $2 \mathrm{r} / 2 \mathrm{ft} \ldots \ldots \ldots . . \$ 70$ each, $\$ 66.00$ per 10
18 to 24 in...... $\$ 5.50$ each, $\$ 51.00$ per 10
15 to 18 in......\$4.50 each, $\$ 42.00$ per 10
12 to 15 in......\$3.50 each, $\$ 33.00$ per 10

\section{NATIVE RHODODENDRONS}

These are unsurpassed for vigor and hardiness.

\section{CAROLINA RHODODENDRON (Rhodo-} dendron carolinianum). A splendid variety growing to six feet, and profusely covered with pink to deep rose blossoms in May.

$$
\begin{aligned}
& 2 \mathrm{r} / 2 \text { to } 3 \mathrm{ft} \ldots \ldots \ldots \ldots \text { each } \\
& 2 \text { to } 2 \mathrm{r} / 2 \mathrm{ft} \ldots \ldots . .50 \text { each, } \$ 42.00 \text { per } 10 \\
& 18 \text { to } 24 \text { in.......\$3.50 each, } \$ 33.00 \text { per } 10
\end{aligned}
$$

CATAWBA RHODODENDRON (Rhododendron catawbiense). Possesses large, round clusters of rosy-lavender flowers in June; rich, dark green leaves.

2 to $2 \mathrm{r} / 2 \mathrm{ft} \ldots \ldots \ldots 4.00$ each, $\$ 36.00$ per 10 18 to 24 in.........\$3.50 each, $\$ 33.00$ per 10 15 to 18 in.........\$3.00 each, $\$ 27.00$ per 10
ROSEBAY RHODODENDRON (Rhododendron maximum). Remarkable for their hardiness. Leaves thick, very large and smooth; flowers white to rose-tinted; blossoms profusely in June and July. This is a handsome specimen plant.

$2 \mathrm{r} / 2$ to $3 \mathrm{ft} \ldots \ldots . . \$ 5.00$ each, $\$ 45.00$ per 10
2 to $2 \mathrm{r} / 2 \mathrm{ft} \ldots \ldots 400$ each, $\$ 36.00$ per 10
18 to $24 \mathrm{in} \ldots \ldots . . \$ 3.00$ each, $\$ 27.00$ per 10

All the above may be collected from their native habitats and sold at reasonable rates in carload lots.

\section{DUTCH PEAT}

We recommend the use of Dutch Peat for both Fine and Broadleaved Evergreens.

$\$ 4.00$ per Bale

$\$ 3.60$ per Bale from 5 to 24 Bales

$\$ 3.40$ per Bale from 25 to 49 Bales

$\$ 3.25$ per Bale from 50 to 100 Ba'es 


\section{Fruit Trees}

\section{STANDARD APPLES}

2 years, 5 to $7 \mathrm{ft}$. : $\$ 1.00$ each; 5 or more of one kind at $90 \mathrm{c}$ each.

$$
\begin{gathered}
\text { Summer Varieties } \\
\text { Fameuse } \quad \text { Red Astrachan } \\
\text { Yellow Transparent } \\
\text { Autumn Varieties } \\
\text { Early Harvest } \quad \text { Fall Pippin } \\
\text { Gravenstein } \quad \text { Wealthy } \\
\text { Winter Varieties }
\end{gathered}
$$

Baldwin Bellflower Delicious

McIntosh Red Northern Spy

Rhode Island Greening Roxbury Russet

Stark Stayman Winesap

\section{CRAB APPLES}

2 years, 5 to $7 \mathrm{ft}$ : : $\$ 1.00$ each ;

$$
\begin{gathered}
5 \text { or more at } 90 \mathrm{c} \text { each. } \\
\text { Variety: Hyslop }
\end{gathered}
$$

\section{STANDARD PEARS}

2 years, 5 to $7 \mathrm{ft}$ : $\$ 1.50$ each; 5 or more of one kind at $\$ 1.25$ each.

\section{Summer Varieties}

Bartlett Clapp's Favorite

\section{Autumn Varieties}

Beurre Bosc Seckel Sheldon

\section{CHERRIES}

2 years, 5 to $7 \mathrm{ft}$ : : $\$ 1.50$ each; 5 or more of one kind at $\$ 1.40$ each.

$$
\text { Sweet }
$$

Black Tartarian Governor Wood

$$
\text { Tart }
$$

Early Richmond Montmorency

\section{PEACHES}

4 to $5 \mathrm{ft}$.: $75 \mathrm{c}$ each; 5 or more of one kind at $60 \mathrm{c}$ each.

Crawford's Early Crawford's Late

Elberta Rochester Stump

\section{PLUMS}

2 years, 5 to $7 \mathrm{ft}$ : $\$ 1.50$ each ; 5 or more of one kind at $\$ 1.40$ each.

\section{Abundance $\begin{gathered}\text { Japanese } \\ \text { Burbank Damson }\end{gathered}$ European}

Bradshaw Lombard

\section{QUINCES}

4 to $5 \mathrm{ft}$ : : $\$ 1.25$ each; 5 or more of one kind at $\$ 1.10$ each. Champion Orange

\section{Small Fruits}

\section{ASPARAGUS}

2-year Roots, $\$ 1.00$ per 25, $\$ 3.00$ per 100 . Conover's Colossal Giant Argenteuil Martha Washington Palmetto

\section{BLACKBERRIES}

$$
\text { Erie Eldorado Snyder }
$$

\section{GRAPES}

2 years: $60 \mathrm{c}$ each; 5 or more of one kind at $50 \mathrm{c}$ each; unless otherwise noted.

Blue-Black

Concord Camplell's Early Worden

Agawam Brighton Delaware Salem

\section{White \\ Niagara Moore's Diamond \\ Green Mountain-75c each, 5 or more at 65 c}

\section{RASPBERRIES}

$\$ 1.25$ per $10 ; \$ 10.00$ per 100 .

Columbian Cuthbert Golden Queen Herbert St. Regis

\section{RHUBARB}

50c each; 5 or more at $45 \mathrm{c}$ each.

Variety: Linnaeus

\section{Anniversary Fruit Tree Collection}

1 Red Astrachan Apple

1 McIntosh Red Apple

1 Baldwin Apple

1 Bartlett Pear

1 Stump Peach

5 Trees

Anniversary Special Offer - - $\$ \mathbf{\$ 4} 40$ Regular Price, $\$ 5.25$ 


\section{Roses}

NATURE will never produce a more perfect flower than the rose. They are of comparatively easy culture when one considers the pleasure their rare beauty gives. Some have individual charm in their wax-like exquisiteness, others-such as the Ramblers-clothe in colorful profusion arbors or rocky walls.

Choose freely from the lists below, and experience the joy of the rose grower.

Strong field-grown plants, 2 years old, $\$ 1.00$ each; 5 or more of one kind at $90 \mathrm{c}$ each, unless otherwise noted.

If we are out of the variety ordered, we shall select the variety most closely resembling it, UNLESS OTHERWISE ADVISED.

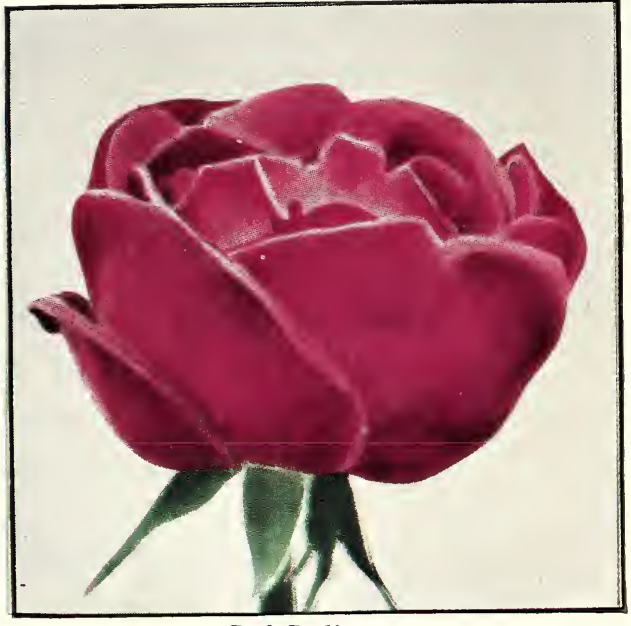

Red Radiance.

\section{Hybrid Perpetual Roses} RED

Gen'l Jacqueminot. Bright scarlet crimson. Hugh Dickson. Brilliant crimson, shaded with scarlet.

M. P. Wilder. Cherry carmine.

Ulrich Brunner. Brilliant cherry-red.

\section{PIN K}

Anne de Diesbach. Large double carmine. Clio. Large flesh color; rosy-pink center. Mme. Gabriel Luizet. Light silvery pink. Magna Charta. Pink and carmine.

Mrs. John Laing. Large soft pink; fragrant and steady bloomer.

Paul Neyron. Deep rose, very large.

\section{W HITE}

Frau Karl Druschki (Snow Queen). Pure white.

Mme. Plantier. Pure white.

Margaret Dickson. White with pale flesh center; large.

\section{YELLOW}

Harison's Yellow. Bright yellow, semidouble.

Persian Yellow. Deep yellow.

\section{Hybrid Tea Roses RED}

Betty Uprichard. Copper-red buds, semidouble orange-carmine flowers.

Etoile de France. Large double velvety crimson ; center ruby red.

Gruss an Teplitz. Scarlet, shading to velvety crimson.

Red Radiance. Similar to Radiance, only deep red.

\section{PIN K}

Dame Edith Helen. New variety; large blossoms of pure pink.

Briarcliff. Handsome flowers of silvery rose-pink.

Jonkheer J. L. Mock. Deep carmine-pink.

Killarney Queen. Long pointed buds of deep shell pink.

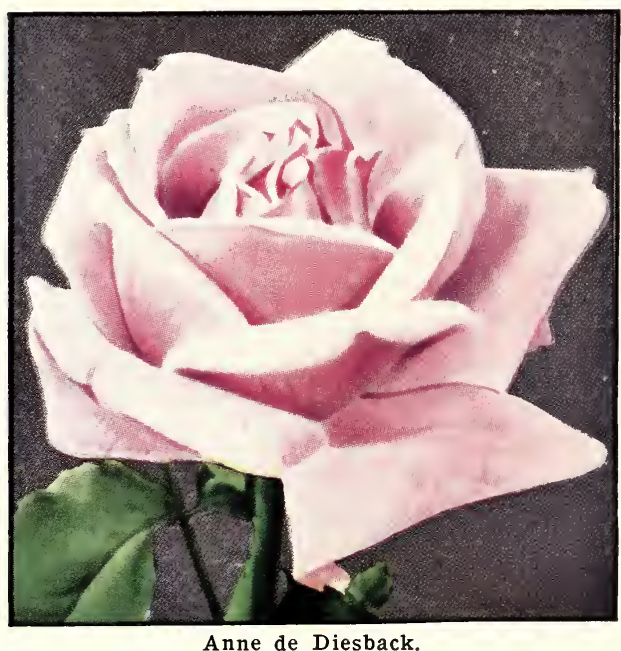

Anne de Diesback. 
Lady Alice Stanley. Outside petals coralpink, inside pale flesh pink.

Mme. Butterfly. Large brilliant pink flowers suffused with apricot and gold.

Ophelia. Salmon flesh, shaded with rose.

Radiance. Brilliant carmine-pink, with salmon-pink and yellow shadings.

\section{WHITE}

Killarney White. Pure white, long pointed buds.

William R. Smith. Creamy white, suffused with rose-pink.

\section{YELLOW}

Golden Ophelia. Beautiful yellow form of the lovely Ophelia.

Independence Day. Flaming yellow buds shaded copper.

Mrs. Aaron Ward. Coppery orange in open bud, pinkish fawn when full.

MRS. CALVIN COOLIDGE. Buff yellow, orange centered.

Rev. F. Page Roberts. Go $1 \mathrm{~d}$ e $n$ yellow blooms stained with copper on outer petals.

Souvenir de Claudius Pernet. New rose of beautiful sunflower yellow, brilliant green foliage and few thorns.

Talisman. Sensational new brilliantly-colored rose of bright yellow, gold and pink. $\$ 1.50$ each, $\$ 12.50$ per 10 .

\section{Polyantha Roses}

Ellen Poulson. Bright rose-pink.

Ideal. Velvety dark red.

Miss Edith Cavell. Scarlet red.

\section{Climbing Roses}

Strong Field-Grown Plants, $75 \mathrm{c}$ each; 5 or more of one kind at 60c each; unless otherwise noted.

RED

Climbing American Beauty. Large crimson flowers.

Crimson Rambler. Immense clusters of double crimson flowers.

Excelsa. Double crimson flowers; good foliage.

Hiawatha. Single deep crimson, clear white at base of petals.

Paul's Scarlet Climber. Vivid scarlet.

\section{PIN K}

American Pillar. Singly rosy-pink.

Dr. Van Fleet. Deep flesh pink.

Dorothy Perkins. Shell pink.

Mary Wallace. Semi-double, bright clear rose-pink. $\$ 1.00$ each, 5 or more at 90c.

Tausendschon. Large trusses pink flowers.

\section{W HITE}

Silver Moon. Semi-double, pure white flowers.

White Dorothy Perkins. Double pure white flowers.

\section{YELLOW}

G a r d e nia. Buds bright yellow, flowers cream. Very hardy.

\section{Rosa Rugosa Hybrids}

$\$ 1.00$ each; 5 or more of one kind at $90 \mathrm{c}$ ea. Hansa. Reddish violet; double.

Sarah Van Fleet. New variety of medium rose-pink.

Sir Thomas Lipton. Doulle white.

\title{
Anniversary Rose Collection
}

\author{
Anniversary Collection No. 16
}

This collection contains five of the best varieties. All are number one sizes, two years old, and will bloom this summer. A wonderful value and saving.

$$
\begin{array}{ll}
\text { Mrs. Aaron Ward } & \text { Killarney Queen } \\
\text { Killarney White } & \text { Betty Uprichard }
\end{array}
$$

Red Radiance

\section{Anniversary Special Offer . . . . . . . \$3.95 \\ Regular Price $\$ 5.00$}




\section{CONDITIONS OF SALE}

\section{Please Read Before Ordering}

TERMS: We reserve the right to change prices quoted without notice.

Cash with orders for goods amounting to $\$ 10.00$ or less.

Twenty-five per cent of the total amount with orders for goods exceeding $\$ 10.00$; the goods to be shipped C. O. D. for the balance.

Charge accounts with thirty day privilege will be extended when suitable trade and bank references are sent.

Club Plan of Payment: At the suggestion of many of our patrons, we have adopted an optional partial payment plan. The initial cost of a satisfactory planting is met in monthly payments, arranged with the customer. If you wish to adopt this method, write "Clul Plan" on the order.

RATES: 1 to 4 plants of one kind and size will be priced at the single rate. 5 to 24 plants of one kind and size will be priced at the ten rate.

Write for special prices on larger quantities.

ADJUSTMENT: Any errors or omissions on our part will be satisfactorily adjusted if notification is given within five days after receipt of goods.

OUR GUARANTEE: We guarantee that our stock is true to name, vigorous and healthy at time of shipment or we replace or refund money paid at buyer's option. We shall not lie held liable for a sum greater than the original sale price.

INSPECTION: Our Nurseries are inspected yearly by an authorized State Inspector, and a copy of our certificate is enclosed with every shipment.

SUBSTITUTION: Occasionally a late order finds our stock depleted of a certain desired plant. We believe we can best serve you by making a careful substitution of the nearest match. If you prefer not to have us do this, write "No Substitution" on your order.

TRANSPORTATION: Our goods are sold F. O. B. Abingdon and travel at the owner's risk and expense. Damages in transit should be taken up immediately with your Express or Freight Agent.

SHIPPING SEASON: Our Spring Shipping Season begins about March 25th and lasts into June.

The Fall Season begins in August and lasts until the ground is frozen.

TRUCKING: We will make deliveries within a radius of one hundred miles, and charge according to mileage and size of truck used. Stock so shipped arrives quickly and in as perfect condition as when it leaves our Nursery.

MEMBERS OF

American Association of Nurserymen

National Home Planting Bureau

New England Nurserymen's Association

Massachusetts Nurserymen's Association 


\section{The A B C's of Planting}

I. Locate plants by setting stakes in the ground. It's easier to move a stake than a plant.

2. Spade, turning sod under, and pulverize area to be planted to a depth of at least twelve inches.

3. Dig holes one foot broader than the spread of the roots, and from two to four inches deeper than they were planted in the nursery.

4. Set the plant in the hole one inch deeper than it was in the nursery. This can be determined by the "collar" just above the roots.

5. Fill in with pulverized soil, shaking the plant gently up and down during the operation to sift the soil around the roots.

6. Firm the soil two or three times while filling in to exclude all air.

7. Leave the last inch of soil loose to act as a dust mulch. Do not make a mound of soil around the plant.

8. Water until the soil is thoroughly saturated to the bottom of the roots. Be sure. Dig down a short distance from your plants.

9. Top fertilize the soil once or twice a year. Never allow fertilizer or manure to come in direct contact with the roots.

I0. Cultivate frequently to keep your plants growing vigorously.

II. Do not expose the roots to the sun or wind longer than is absolutely necessary.

12. Do not hurry with your planting. Take time to do it well. It pays to make your plants feel at home and happy.

If you desire further information ask us. We will cheerfully answer any questions, giving you the benefit of our twenty-five years experience in growing fine plants. 
LITTLEFIELD-WYMAN NURSERIES NORTH ABINGTON, MASS. 